Fall 1938

\title{
1938 Cedrus Yearbook
}

\section{Cedarville College}

Follow this and additional works at: https://digitalcommons.cedarville.edu/yearbooks

Part of the Higher Education Commons, Organizational Communication Commons, and the Public Relations and Advertising Commons

\section{Recommended Citation}

Cedarville College, "1938 Cedrus Yearbook" (1938). Yearbooks. 71.

https://digitalcommons.cedarville.edu/yearbooks/71

This Book is brought to you for free and open access by DigitalCommons@Cedarville, a service of the Centennial Library. It has been accepted for inclusion in Yearbooks by an authorized administrator of DigitalCommons@Cedarville. For more information, please contact digitalcommons@cedarville.edu. 


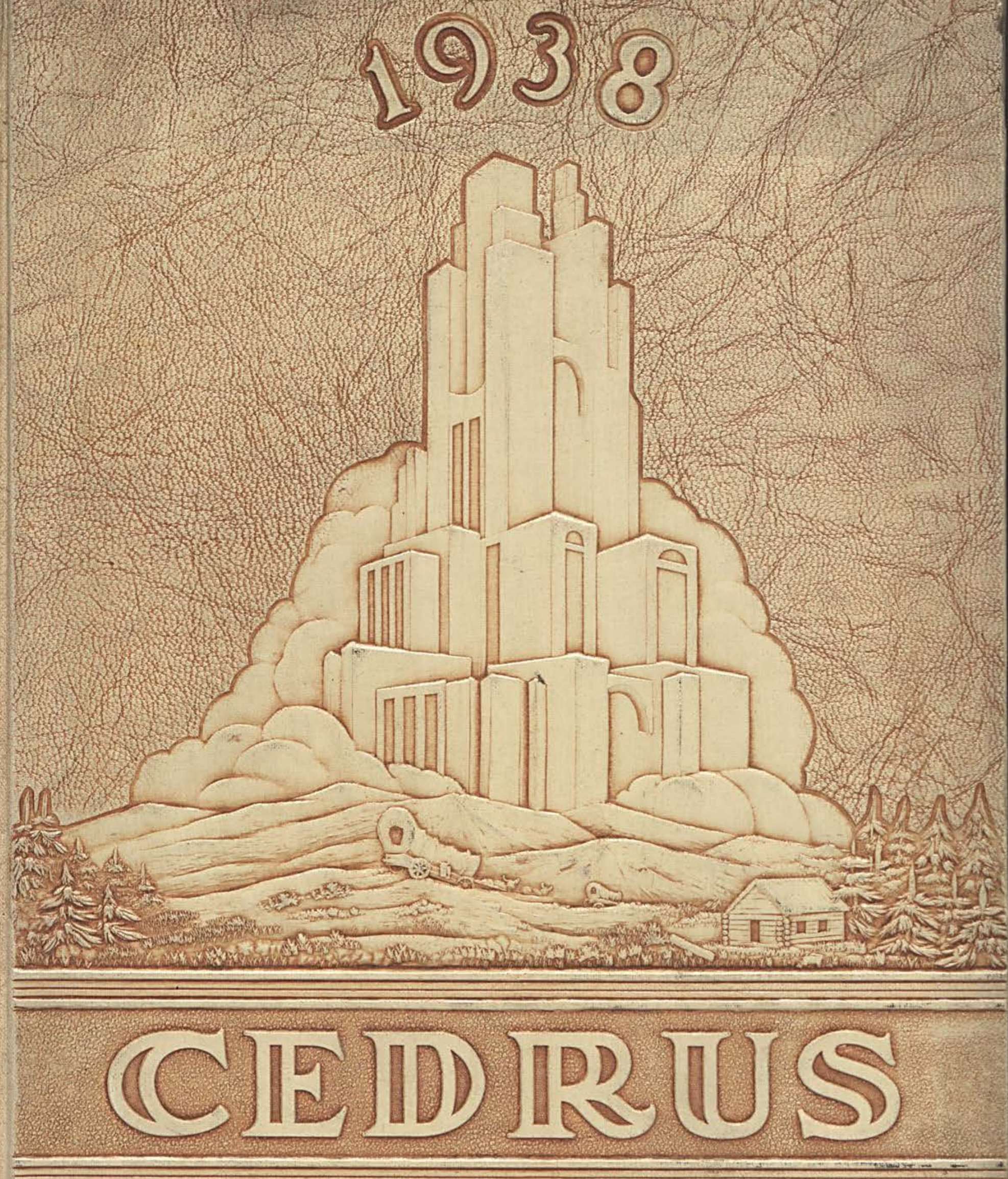





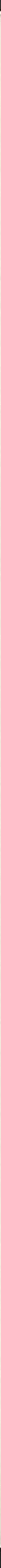




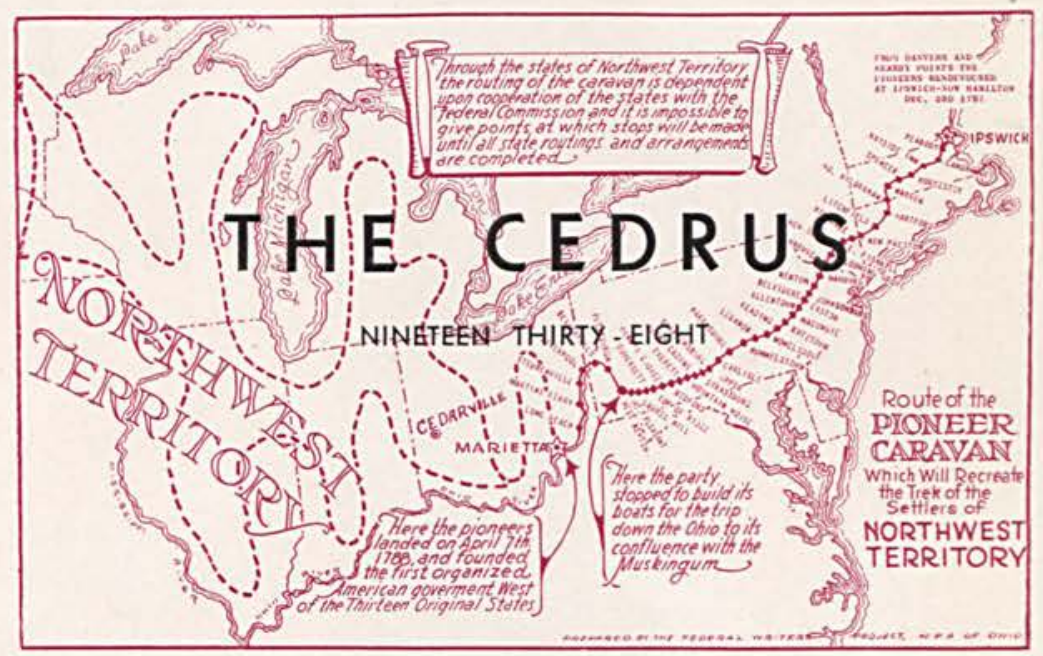




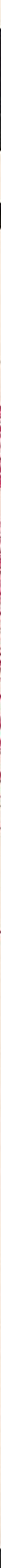




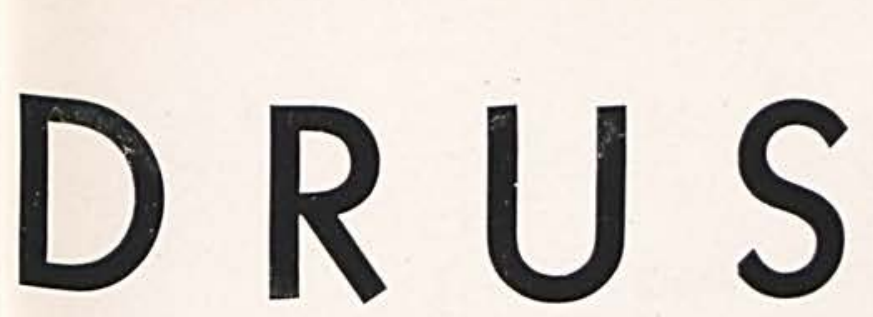

\section{THIR T Y - E I G H T}
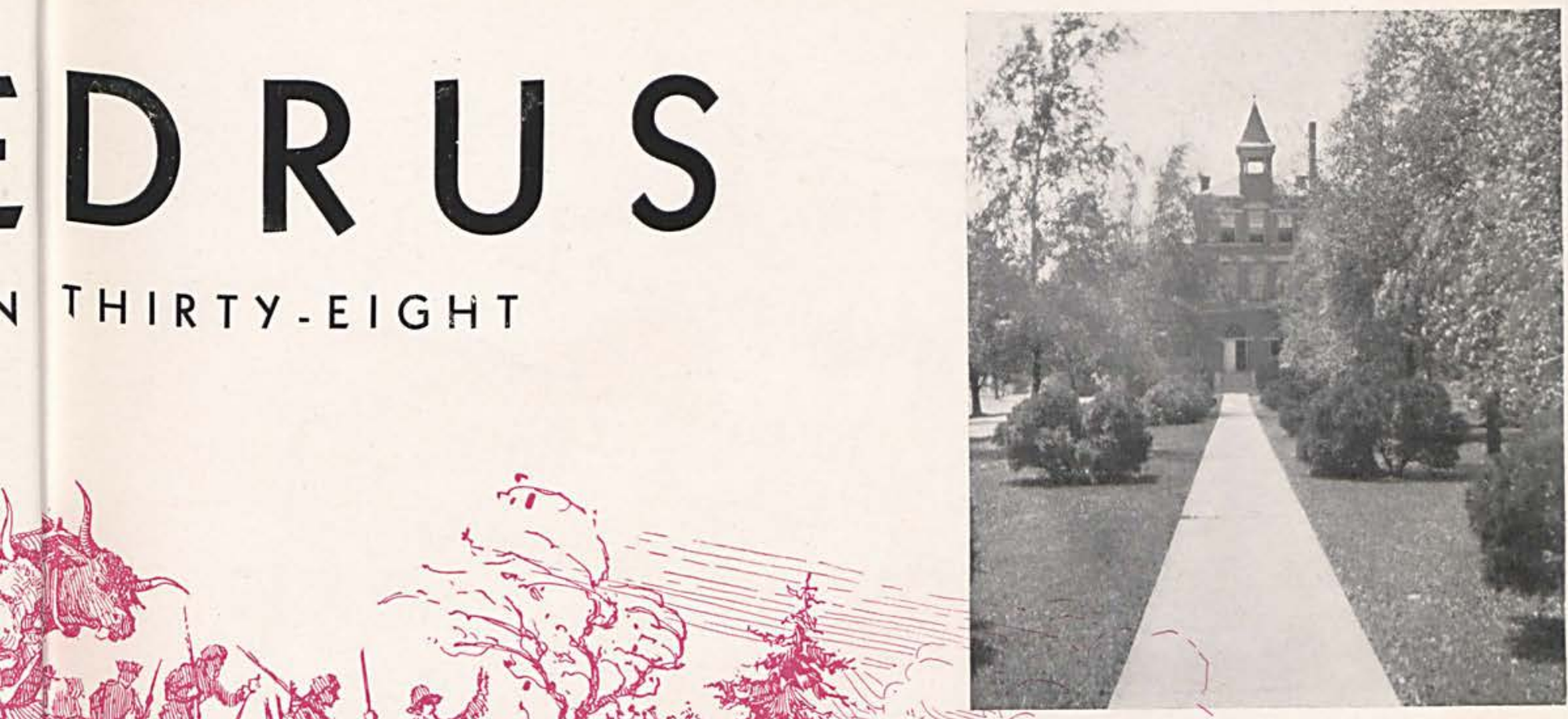

(2) 14 (1) ch (n)

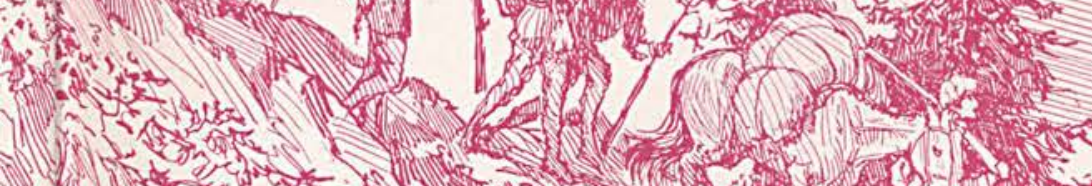
1.1 15.

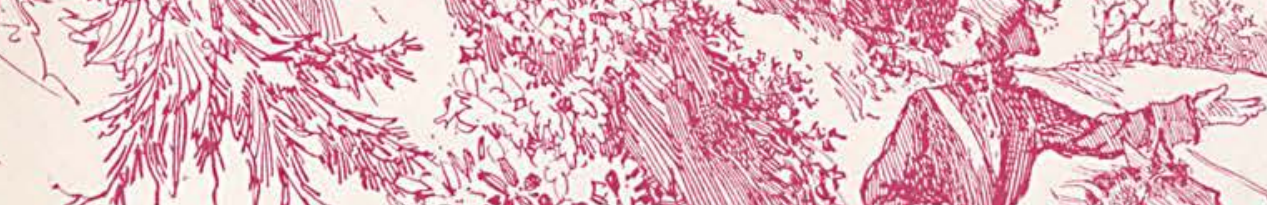

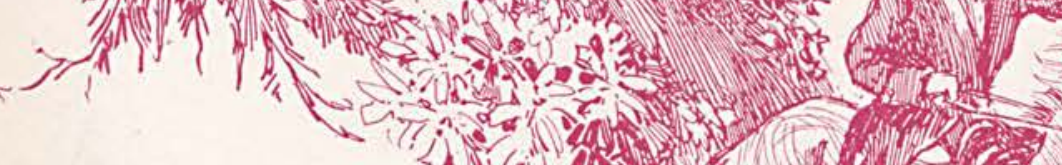

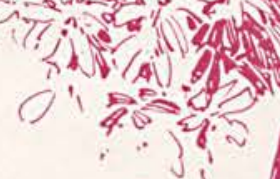

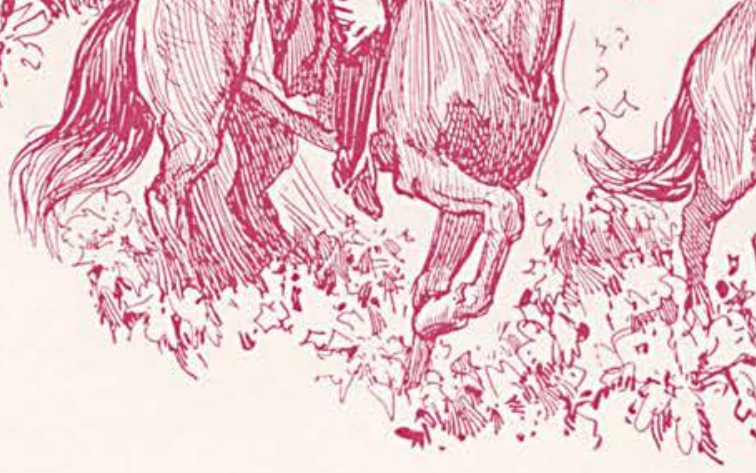


Thaxpwath

(4)

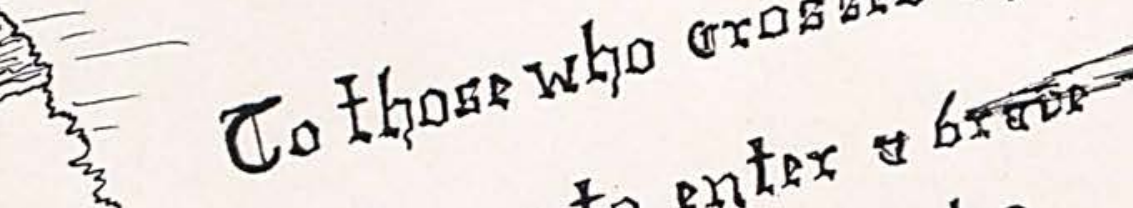
3nentaing to entex of who

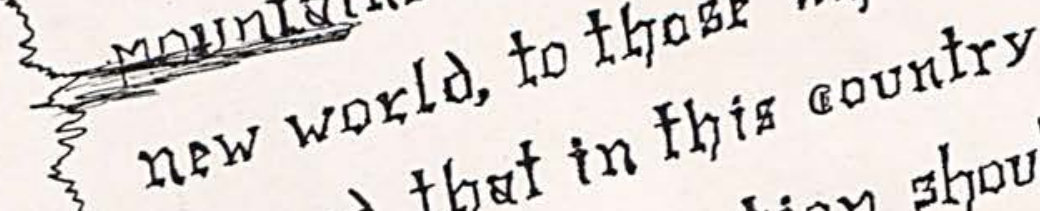
Deerend that in the ention should

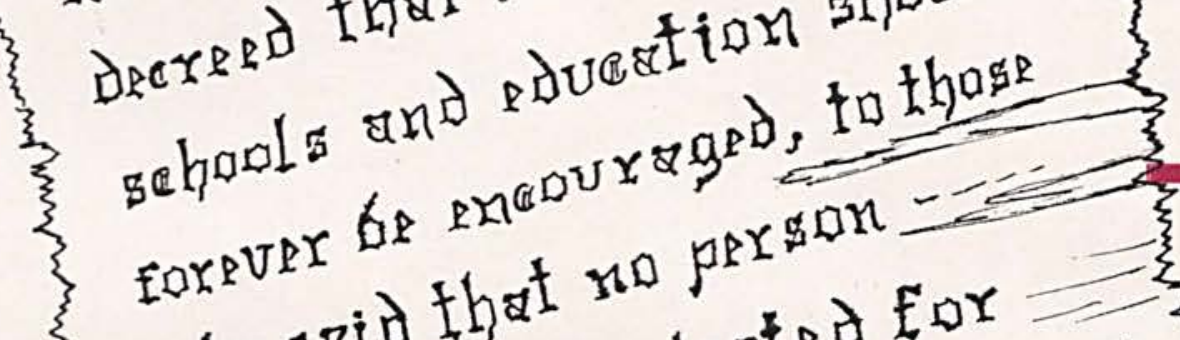
who gaid that ro moleted for 3 shauld eur tor male tamert and

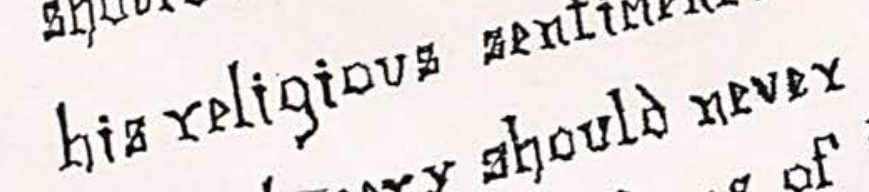
3)

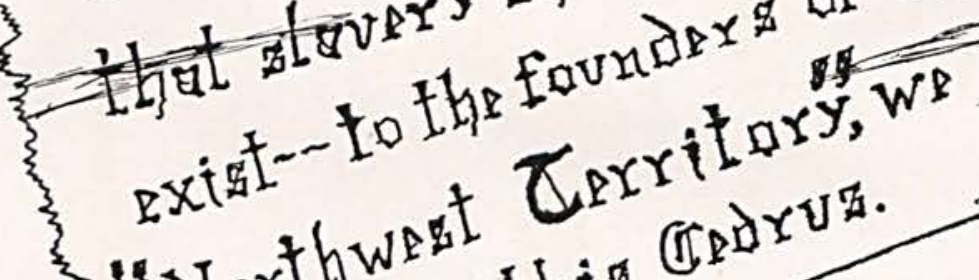
"Noxthwet the crodxut. Dodtexte 


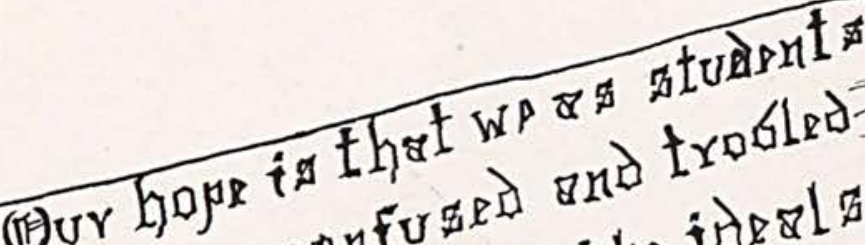

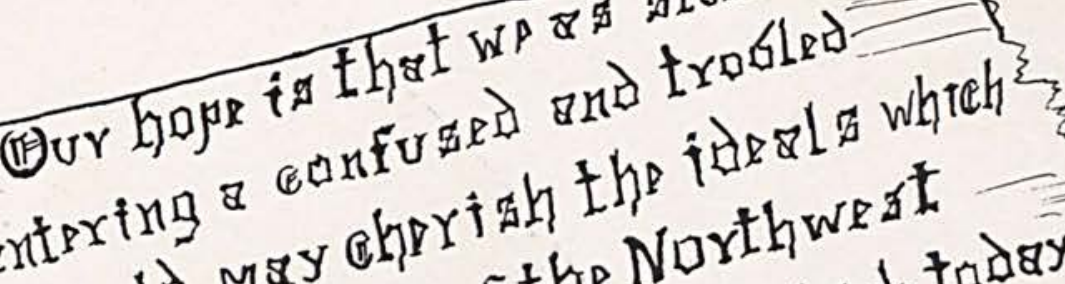

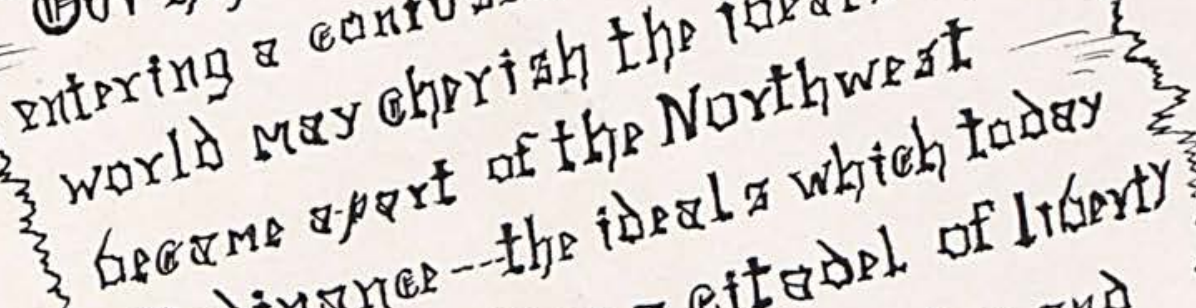

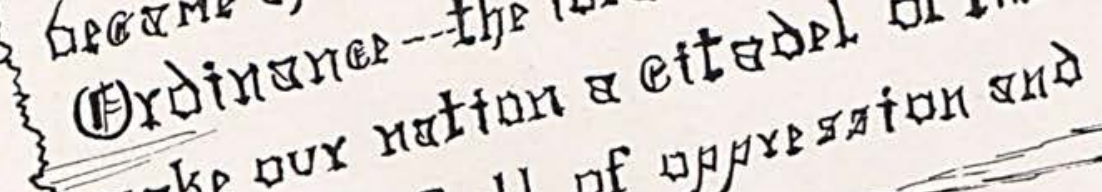

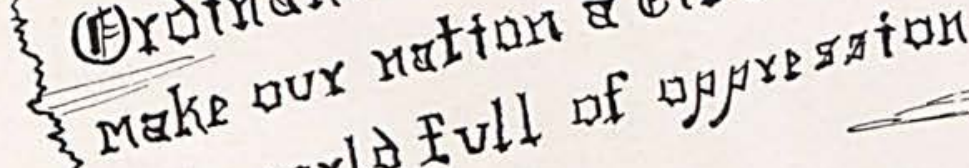

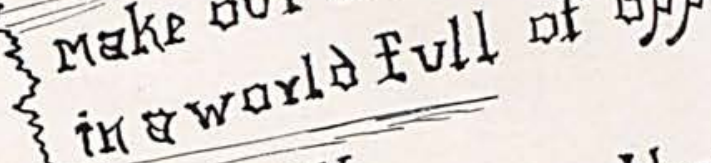
IyI

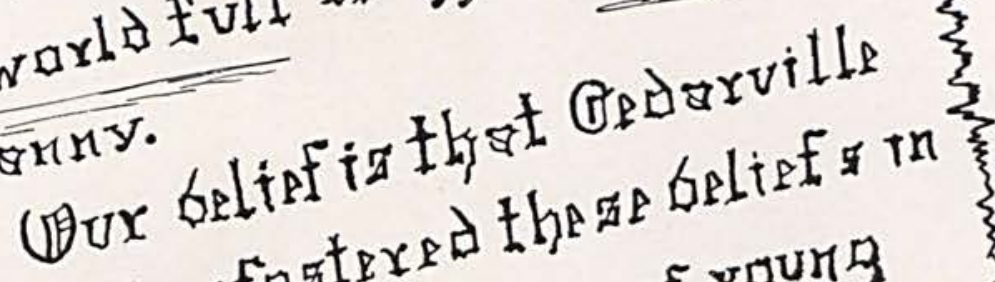
(Tollege-hasefotered the of yaum

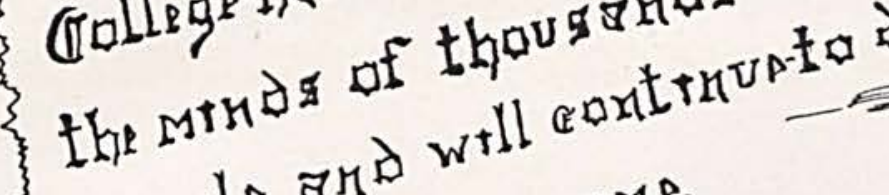
$\xi$ penple ard will earta eamp.

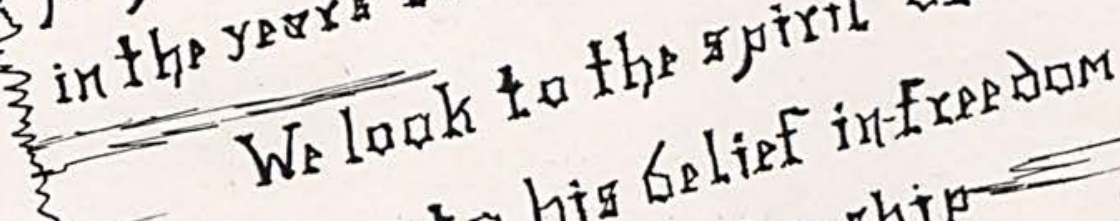

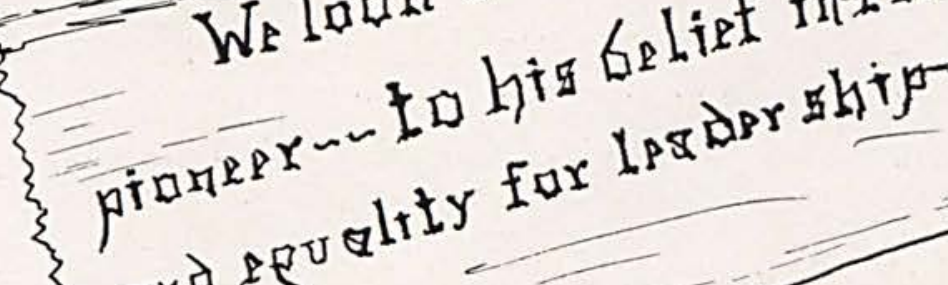

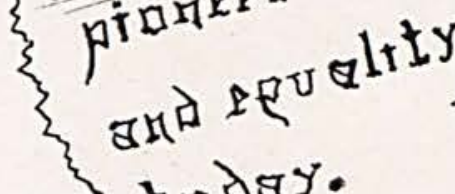
(ㄷ) 


\section{THE}

ADMINISTRATION 


\section{THE CARNEGIE LIBRARY}

The Carnegie Library Building includes not only the library but the cooperative boarding club room, the social room, and the music studios.

The Carnegie Library has recently been redecorated and has been made a part of the Greene County library association. Many new books have been added to the volumes already there.

THE LIBRARY

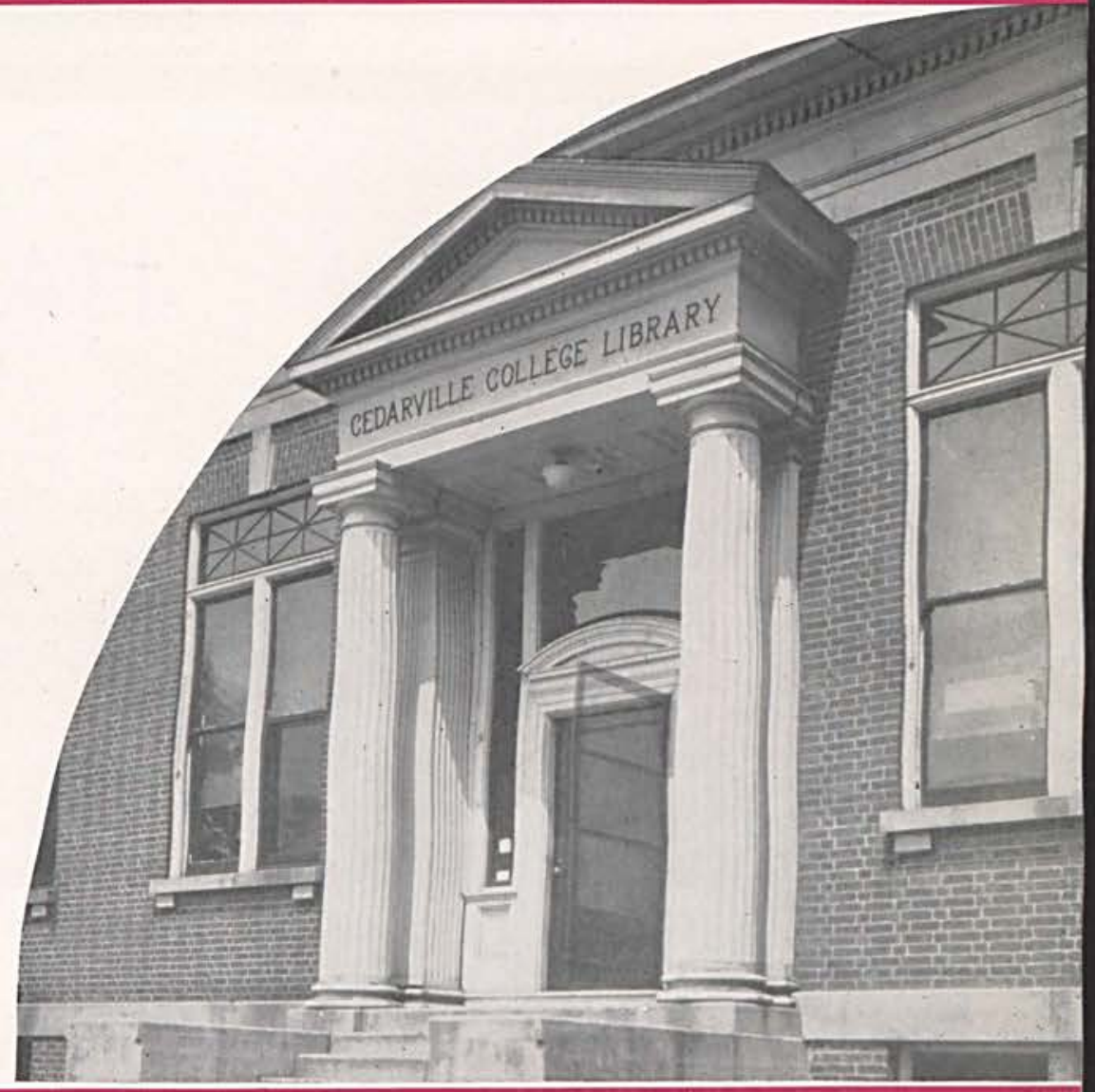




\section{THE \\ GYMNASIUM}

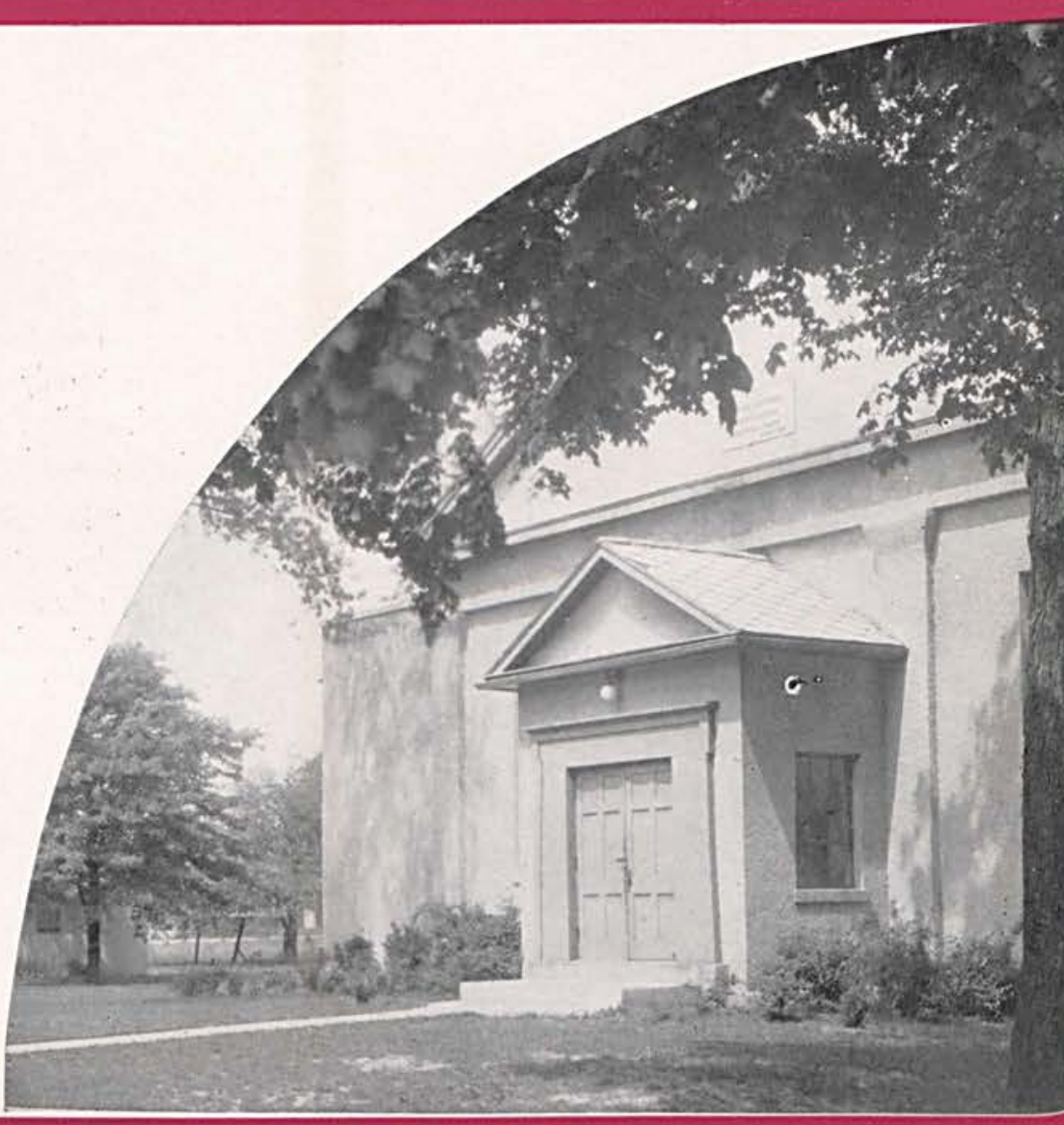

THE ALFRED MEMORIAL GYMNASIUM

The Alfred Memorial Gymnasium is the social center of the campus. Breath-taking minutes in basketball games, hilarious times at parties, the fellowship of banquets - all of these things take place in the gymnasium.

THE 1938 CEDRUS 
THE SCIENCE HALL

The Science Hall is the newest addition to the College Campus. Students spend many long hours in this building investigating facts of the world of science. All of the laboratories are in this building. Most of the educational classes are also found here. This building was also redecorated last summer.

THE SCIENCE HALL

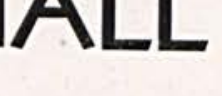




\section{Administration}

Chese piomeers gave eberpthing to the development of this new nation -new not only in years but in principles and ioeals.

Che adminigtrators of Cedarville College have shown a rare debotion to their task of leading students into a richer and better way of life. 


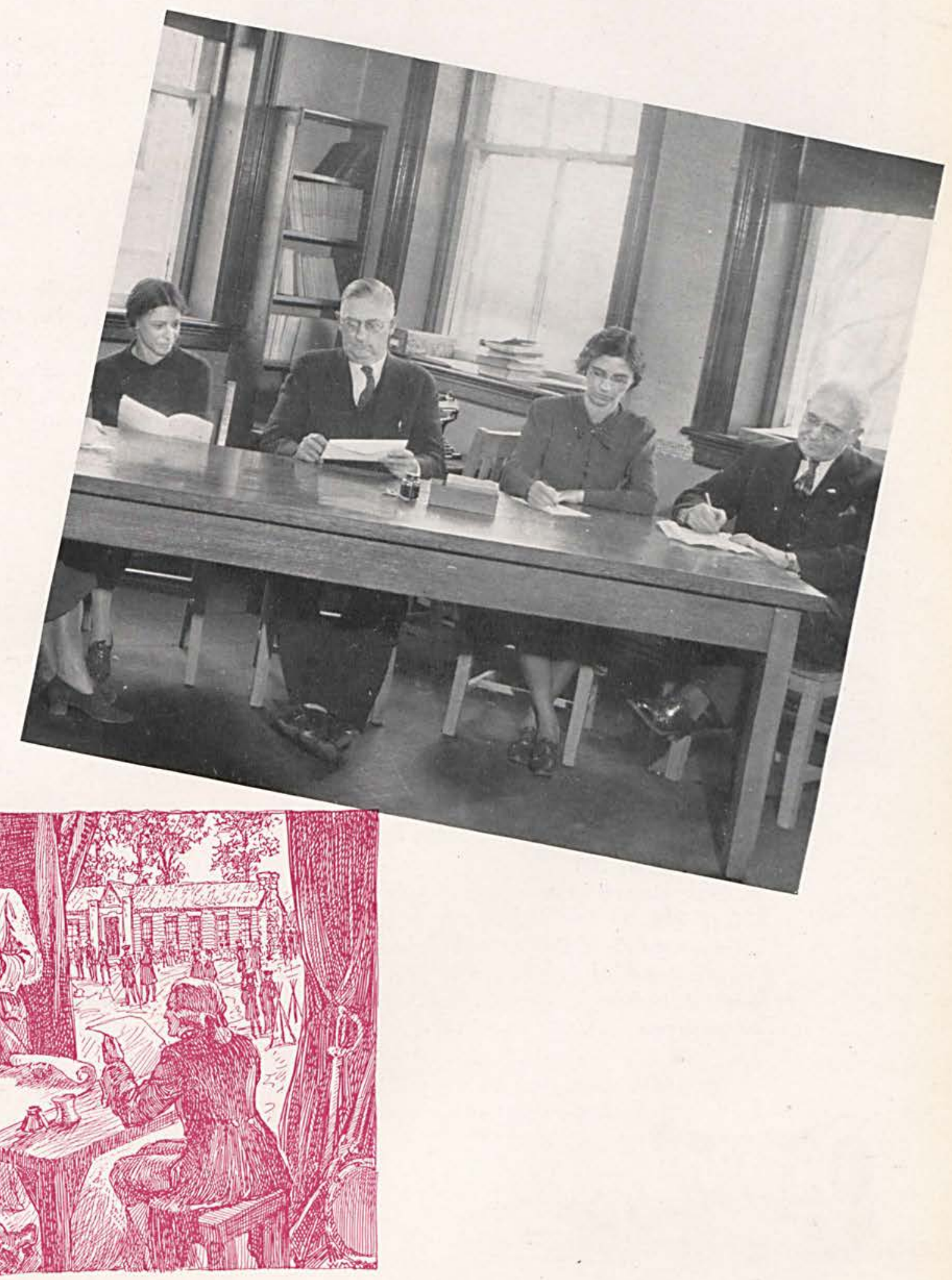


BOARD OF TRUSTEES

W. Clyde Howard, D.D.

President

M. I. Marsh

Wm. H. Tilford, D.D.

S. C. Wright

Vice-President

Secretary

Treasurer

Term Expires 1938

George H. Hartman

Cedarville, Ohio

Walter C. Iliff

Cedarville, Ohio

James L. Chesnut, D.D.

Fairmont, W. Va.

Wm. R. Graham, D.D.

Lafayette, Ind.

J. Loyd Confarr

Cedarville, Ohio

W. R. McChesney

Cedarville, Ohio

Term Expires 1939

Karlh Bull

Cedarville, Ohio

R. W. Ustick, D.D.

Wm. R. Collins

Springfield, Ohio

Wm. H. Tilford, D.D.

Wilmette, III.

Miron I. Marsh

Cincinnati, Ohio

William Conley

Cedarville, Ohio

Cedarville, Ohio

Term Expires 1940

W. P. Harriman, D.D.

Cedarville, Ohio

W. Clyde Howard, D.D.

Chicago, III.

S. C. Wright

Cedarville, Ohio

S. Frank Creswell

Cedarville, Ohio

Harry G. Pounsford

Cincinnati, Ohio

Dwight R. Guthrie

Springfield, Ohio

George Brewer, D.D.

Piqua, Ohio

Page Fourteen 


\section{PRESIDENT}

Dr. W. R. McCHESNEY

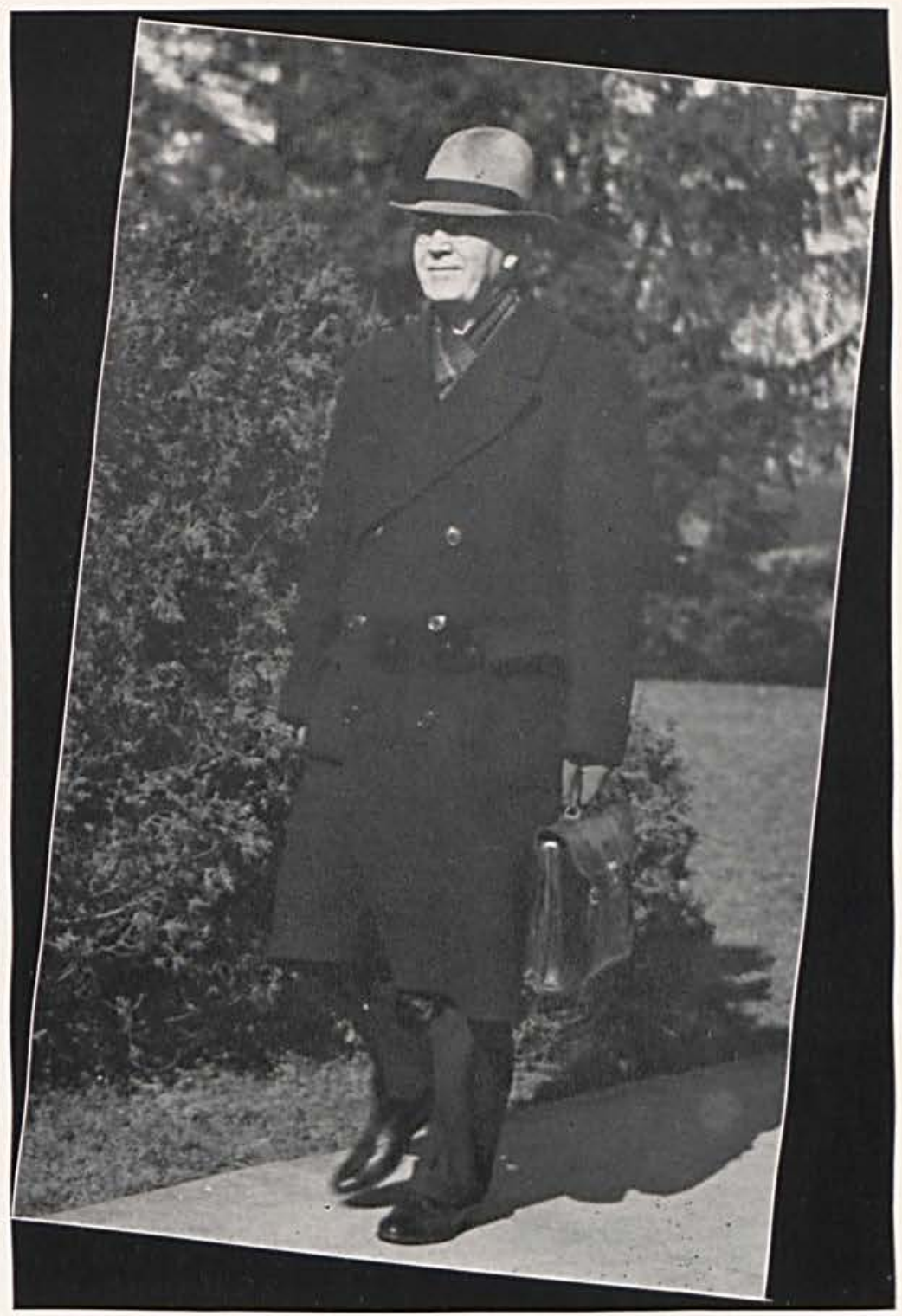

His inspired teaching, his loyal devotion, his friendly counsel and guidance have endeared him to students for almost half a century. Under his leadership Cedarville College has sent young men and women into all walks of life with a sense of duty to their fellow-men.

Through his classes he helps students find their great heritage of knowledge; through sermons and speeches he inspires multitudes and through public service he ardently upholds the ideals of temperance and education.

Dr. McChesney had given his life to Cedarville College. He has worked unfalteringly for the success and growth of this institution, and it is our hope that his dreams for Cedarville will soon be realized. 


\section{ADMINISTRATION"}

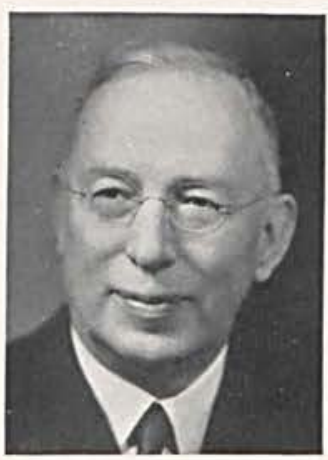

\section{J. L. Dorst}

Business Manager of College

\section{W. Steele}

Dean of Men

Professor of Social Science

A. B. Indiana Teacher's College

M. S. Northwestern University

\author{
Helen H. Santmyer \\ Dean of Women \\ Professor of Latin and English \\ B. A. Wellesley College \\ B. L. H. Oxford
}
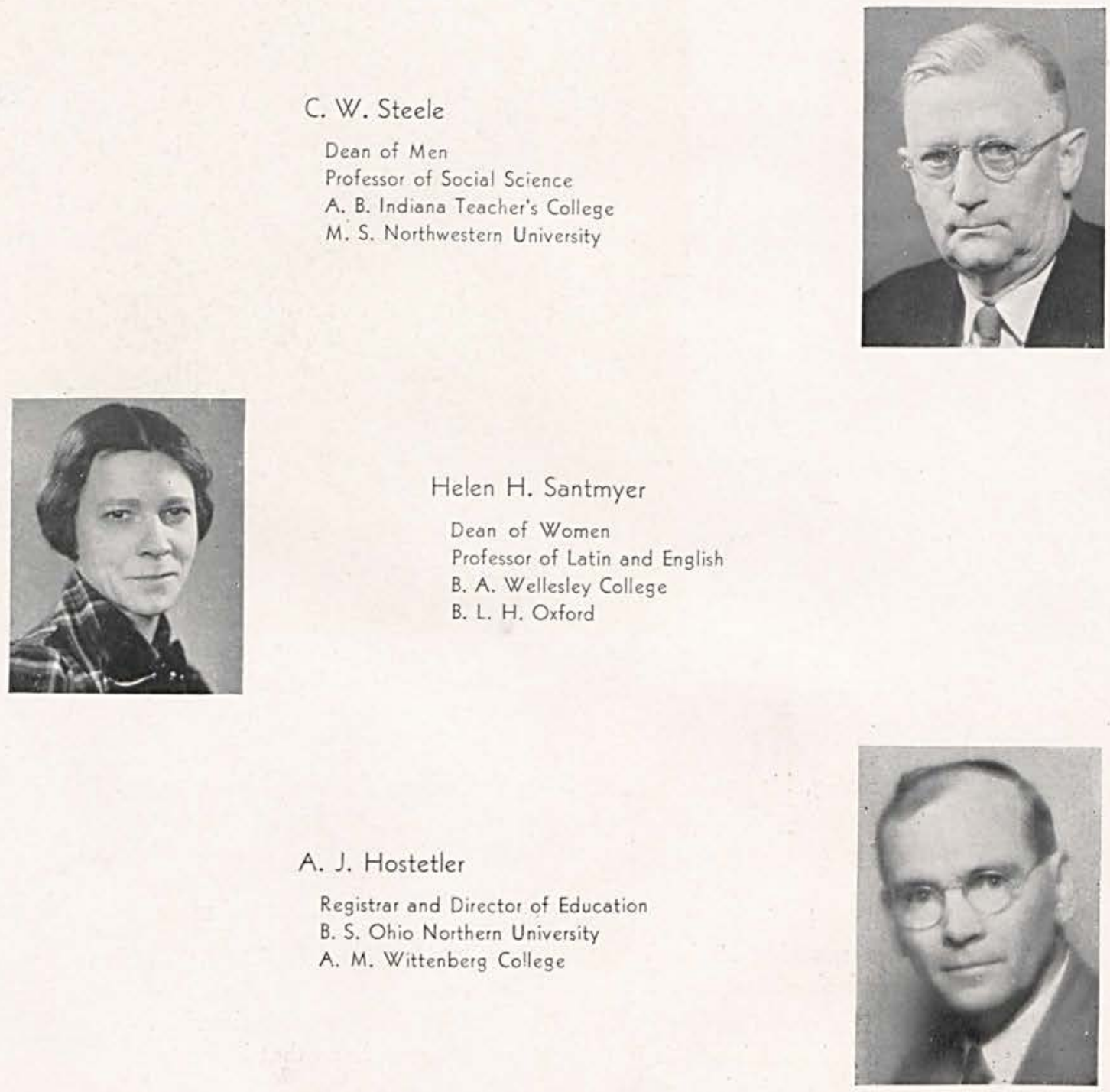

THE 1938 CEDRUS

\section{A. J. Hostetler}

Registrar and Director of Education

B. S. Ohio Northern University

A. M. Wittenberg College 
« $\ll$

$\ll$

E. R. Gibson

Professor of Science

A. B. Cedarville College

A. M. Ohio State University

\section{F ACULTY}

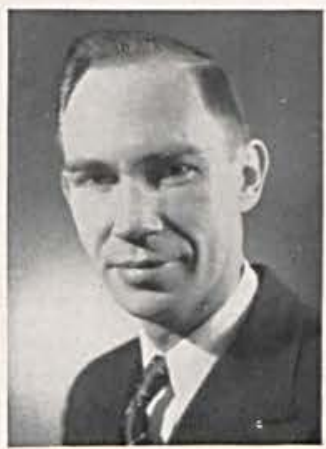

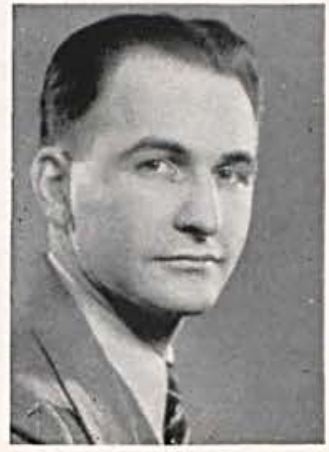

Eloise Kling

Professor of Elementary Ed.

A. M. Wittenberg College

\section{J. W. Ault}
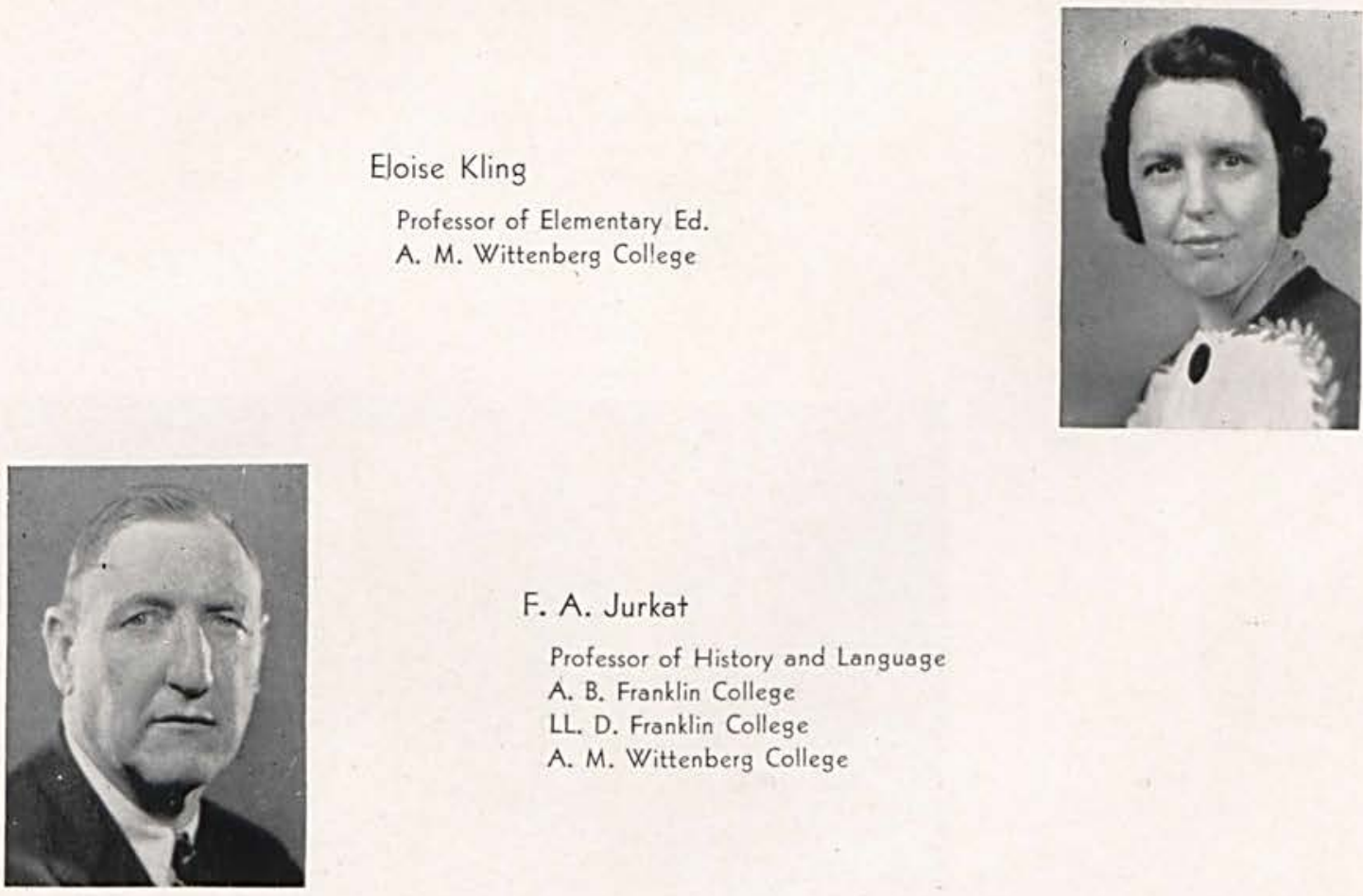

Professor of Mathematics and Physics Director of Physical Education

B. S. Bowling Green State College

A. M. Ohio State University

\section{F. A. Jurkat}

Professor of History and Language

A. B. Franklin College

LL. D. Franklin College

A. M. Wittenberg College

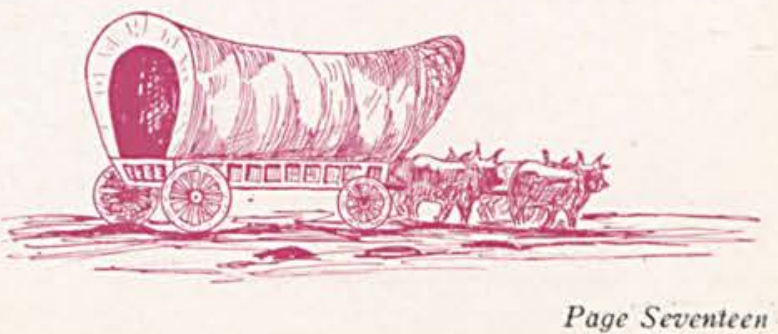




\section{F A C U L T Y}

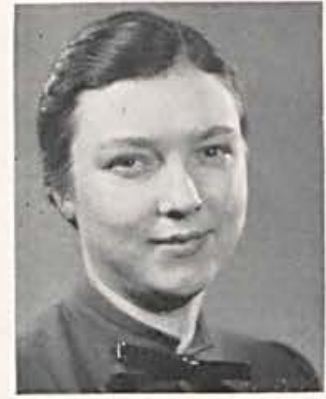

Marguerite Ault

Professor of Debate and French

B. S. Bowling Green State College

Mildred Bickett Creswell

Professor of Music

A. B. Muskingum College

B. M. Muskingum Conservatory

M. M. Cincinnati Conservatory

Diploma, Fontainebleau, France
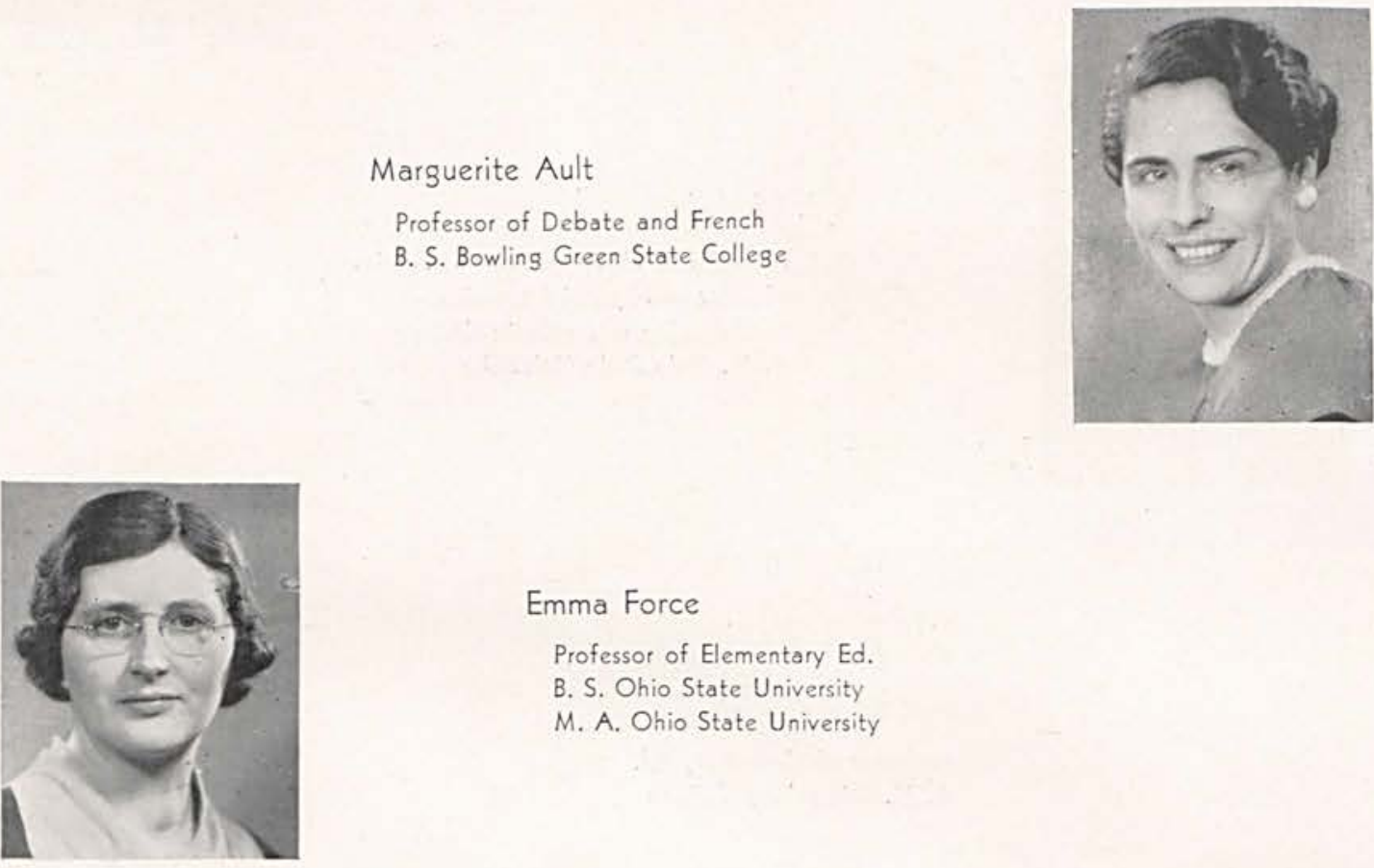

\section{Emma Force}

Professor of Elementary Ed.

B. S. Ohio State University

M. A. Ohio State University

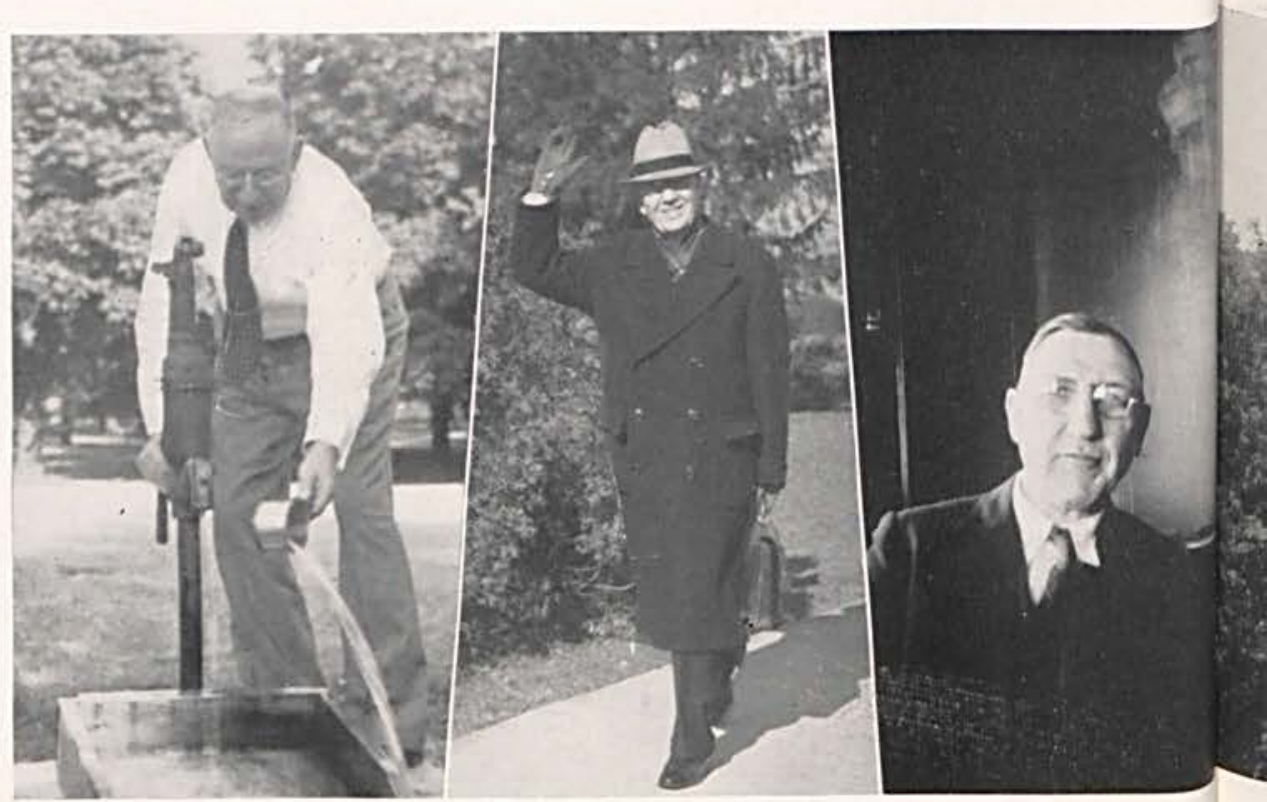

THE 1938 CEDRUS 
"Education and gchoolg shall foreber be encouraged" was a decree of the Rarthwest Droinance. Chis toeal became one of the foumdation stones of American education.

Che clagses of Cedarbille College carre on this national tradition of the spreading of knowledge to all. 


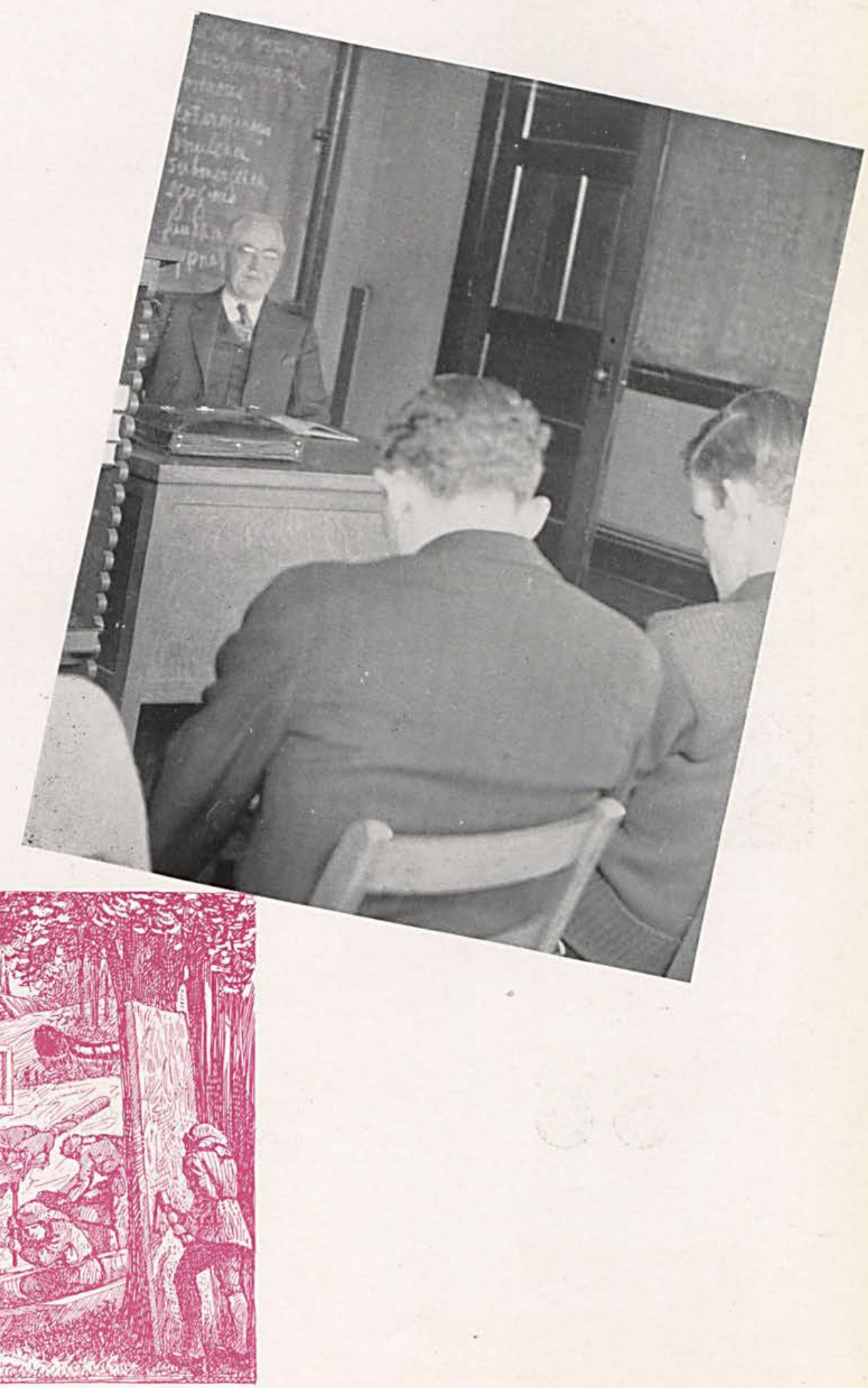

Page Twenty-One 


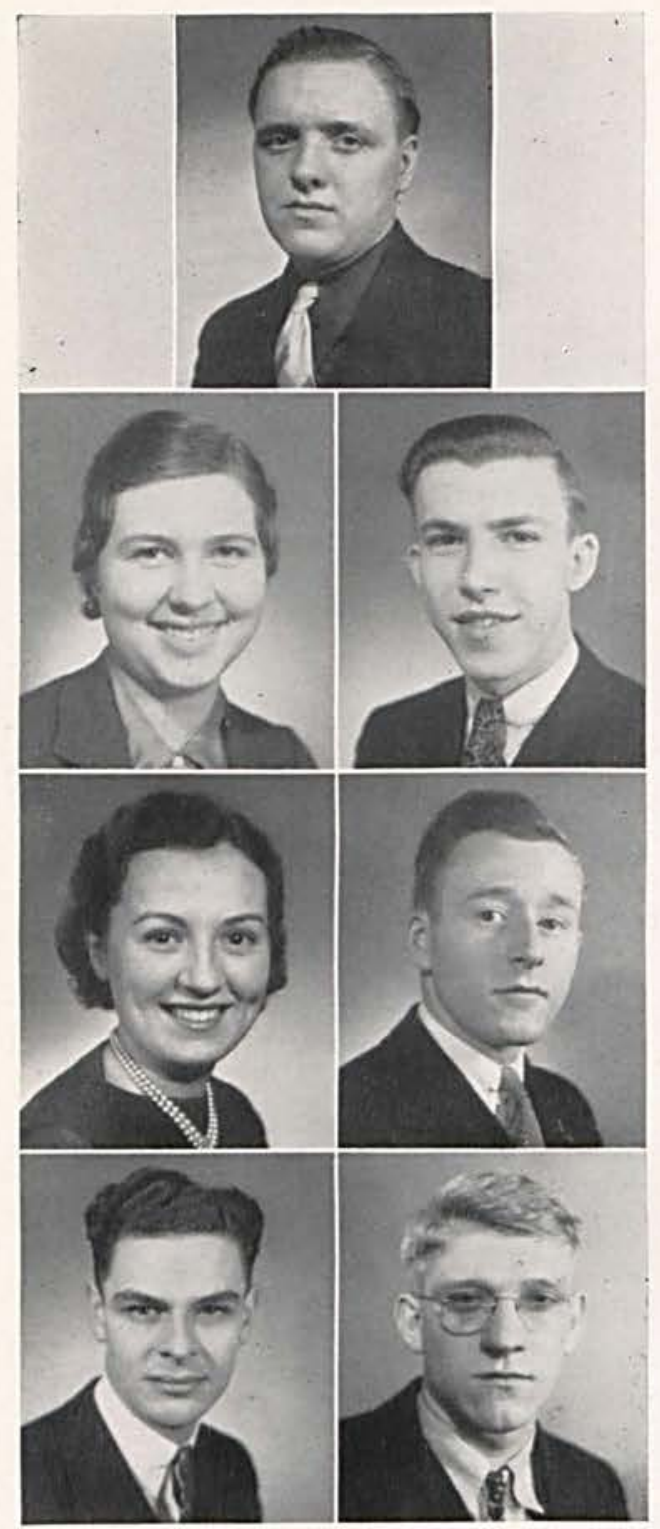

THE CLASS
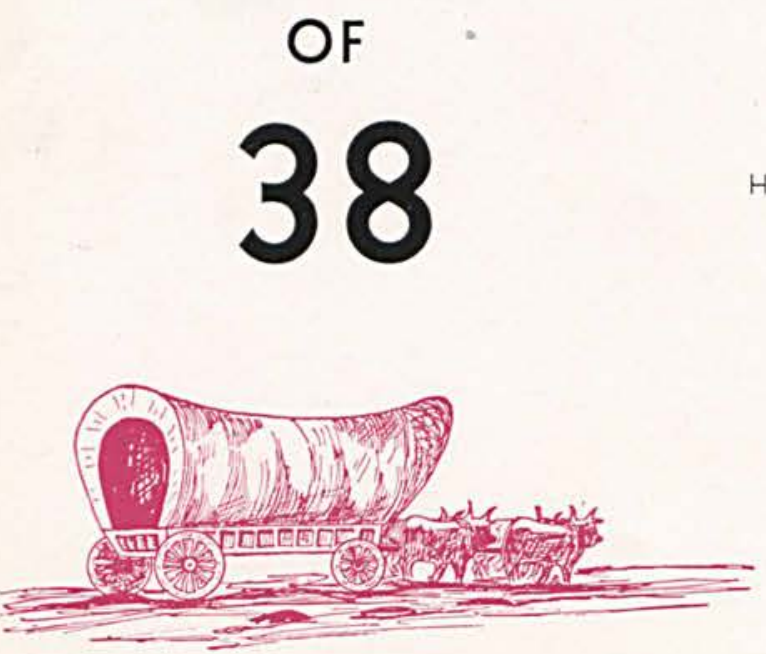

Page Twenty-Two
ROY LINTON: Dramatic Club 1,2,4; president 4; Litewry Society 1,3; officer 3; Basketball 1,2,4; Baseball 1,3; Bible Reading Winner 3: Class officer 1,3,4; Delta Kappa Sigma 3,4; president 4; Boarding Club 1,3,4; Steward 4; Cedrus Staff 4; Whispering Cedars 4; Class Play 3; Minstrel 4; Student Council 4; Y.M.C.A. 1,3,4; officer 3; Social Committee 4.

MARTHA BRYANT: Y.W.C.A. 1,2,3,4; officer 4, Crown Club 3: Chi Sigma Phi 3,4: Whispering Cedars Staff 4: Cedrus Staff 3,4; Class Officer 4; Glee Club Accompanists 3,4; Mixed Chorus organists 4.

JUSTIN HARTMAN: Y. M. 1,3,4; Literary 1,3; Cedrus Play 3: Class Play 3; Dramatic Club 1,3,4; president 3; Whispering Cedars 1,3,4: Editor 3: Cedrus 1,4: Class officer 4: De. bate 1,3,4; Bible Reading Winner 1,3,4.

MARY JOHNSTON: Y. W. 1,2,3,4, officer 2,3,4; Literary 1,3; Class officer 3: Monks' Club 4: Mock Wedding 2,3,4: Cedrus Play 2,3; Glee Club 1,4; Cedrus 2,3,4; Class Play 3; Student Body officer 4; Bible Reading Winner 4; Dramatics 1.3,4; president 4; Boarding Club officer 4 .

KENNETH SANDERSON: Y. M. 1,2,3,4, president 4; Literary 1,2,3; Class president 3 , officer 4 ; class play 3 ; Dramatics 2.3: Quartet 2,3; Monks' Club 3,4: Debate 3; Cedrus 3,4; Student Council 3: Bible Reading Contest Winner 3.

JAMES ANDERSON: Y. M. 1,2,3,4; officer 3; Dramatics 123.4. president 2. Literary 12, officer 1. Whispering Cedars 1,2; Cedrus 2,3,4; Class officer 1,3; Student Body president 4; Cedrus Play 2,3; Mixed Chorus 1,2,3,4; Minstrel 2.4: Debate 1,2,3,4: Lab. Instructor 3,4: Bible Reading Winner 1,2; Class Play 3: Crown Club 3; Student Council 4.

HAROLD SHAW: Cedrus Staff 4: Debate 2,3,4; Y.M.C.A. 1,2,3,4; Whispering Cedars 1,4: Minstrel 2,4; Lab. Instructor 3,4: Crown Club 3: Class Play 3,4; Y.M.C.A. reporter 4. 
HERBERT CUMMINGS: Y. M. 3,4: Dramatics 4; Literary 2,3;

Minstrel 4; Mgr. baseball I; Basketball 2.

JOHN GILLESPIE: Basketball 1,2,3,4; Baseball 1,2,3,4; Delta

Kappa Sigma 3,4; Whispering Cedars 1,4; Class president 2;

Minstrel 2,4; Bible Reading Winner 4; Dramatic Club 1,2,3,4;

Literary 1,2,3; Student Council 2; Y. M. 1,2,3,4; Dramatic

Club Play 4.

HOWARD SWAIM: Basketball 1,2,3,4; Y. M. 2,3,4; Tennis Club 1; Cedrus 3; Class Play 3.

BETTY SHAW: Y. W. 1,2,3,4, officer 4; Class Play 3; Mock

Wedding 2,3,4: Glee Club 4: Cedrus 4: Whispering Cedars

4; Chi Sigma Phi Sorority 4; Student Council 4.

HARRY SINKS: Y. M. 2; Literary I; Bible Reading Contest

1,2,4; Dramatic Club 1; Cheer Leader 1; Minstrel 4.

WILMOTT FISCHER: Denison University Conservatory of Music: Y.M.C.A. 2,3,4; Boarding Club 2,3; Minstrel 4; Y.M.C.A. pianist.

MILDRED MCKIBBEN: Y.W.C.A. 1,2,3; Girl's Glee Club I; Dramatic Club 1,2,4. Western College for Women I; Boarding Club 1,2.

RACHEL CRESWELL: Literary Society 1,2,3; Glee Club president 4; Mixed Chorus 3,4; Dramatic Club 4; Gospel Team 3,4; officer 4; Bible Reading Winner 2,4; Class Play 3; Mock Wedding 4; Y.W.C.A. 1,2,3,4: Lab. Instructor 3.
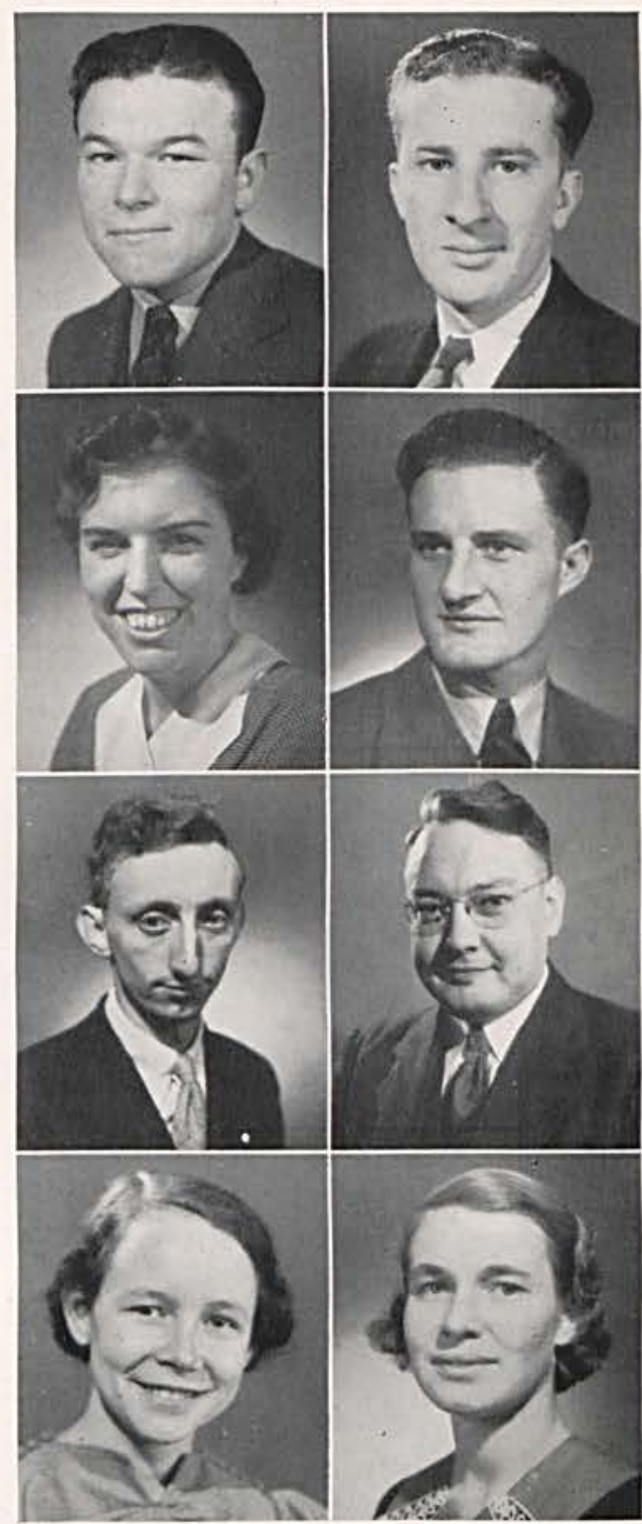

\section{THE CLASS}

OF

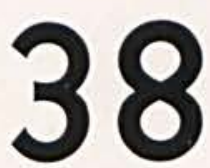




\section{SENIOR CLASS}

These warm sunny days remind me of the day we started to College. As I think back over the years, I smile when I remember our first Freshman party at Anderson's. I laugh outright when I remember how Mrs. Anderson turned the hose on the upper classmen.

In my train of thought come memories of coasting parties, hay rides, Bible Reading contests, pep meetings, snake dances, and pajama parades.

And our Junior Class play! I don't suppose that I shall ever forget it. Roy was so funny, and Justin-! Well, here we are Seniors ready to start out on our own. The good times we had at Cedarville will become a part of our day dreams.

\section{COLLEGE BULLETIN 1950}

We are very glad to hear that Mr. Harry Sinks has been found after having been captured by bandits in Central China some months ago. He is returning to Mrs. Sinks and children in Shanghai.

Coach Roy Linton, the popular baritone, recently led his high school team to the state tournament where they were ignominiously defeated by a score of 50-6.

Congratulations to the former Betty Shaw, class of ' 38 , who is announcing the birth of twin sons, $\mathrm{Uz}_{\mathrm{z}}$ and Buz.

Dr. Harold Shaw has recently published his thesis which was an exhaustive study on "Why Women Close Their Eyes When Kissed."

Mr. Philip Shupp, the eminent physician, was called last week to the home of Miss Suzie Barnes to perform an autopsy on "Poo-Poo," her favorite lap dog.

In the current issue of "Life" we see the smiling countenance of our own Rachel Creswell in an advertisement for Pebeco. Her smile has become nationally known.

There was recently a riot at the Palace Theater where the popular matinee idol, James Anderson, was featured in his second starring vehicle, "My Sin."

Mr. Howard Swaim has fulfilled the dream of half a century of Cedarville College and his own heart, when he endowed Cedarville College with a \$50,000 Dormitory.

The Castle Gardens, just out of Cincinnati, have signed a long term contract starring "Mr. Kenneth Sanderson and his Bevy of Beefy Brunettes." They have originated a new dance which is sweeping the country.

We recently received a letter from Herbert Cummings, Reno, Nevada, where it is reported he is recovering from a weakened condition of the heart. This is Mr. Cummings' second trip to Reno.

It's good to hear that Martha Bryant is recovering in the hospital, where she is being treated for a broken toe. The accident occurred when Miss Bryant stubbed her toe on one of the pedals of the organ at "The Little Church Around the Corner."

Mr. Wilmott Fischer has just completed a successful world tour with his famous Cathedral Choir Boys. They have appeared before the crowned heads of Europe.

Miss Mildred McKibben was recently elected Secretary of the National W. C. T. U. Her activity in this work dated from Cedarville College days.

Mr. Justin Hartman, the eminent professor of Sociology at the J. James Hartman School for Girls, has been conducting an investigation of the Night Clubs in Cincinnati. This is an interest that has long been dear to his heart.

Mrs. Mary Johnston Rosenstein has returned to the stage after a year's leave of absence. She will be featured in her husband's production, "Dimpled Darling."

Mr. John Gillespie, President of the International Women's Garment Union, has been in Ladies' Underwear the last few months organizing that industry.

THE 1938 CEDRUS

Page Twenty-Four 
Harry Sinks-Miniature whirlwind-authority on cats, alligators and Chinese.

Howard Swaim - "Pa, I want to learn how to smoke."

Harold Shaw-His determination should carry him far. Hold It!

Martha Bryant-A good student and ambitious to become an organ professor.

James Anderson-Tall, dark, and handsome.

Kenneth Sanderson-Not especially romantic but might be moved on a moonlight night.

Betty Shaw - If she were a boy and had three brothers, she could be one of the "Four Horsemen."

Rachel Creswell-Her smile is almost as winning as Chubby Linton's.

Roy Linton-Chubby's cute smile will be missed by the girls of C. C. next year.

Herbert Cummings-Hobbies: wine, women, and song.

Mary Johnston-She uses her dimples to sood advantage.

Philip Shupp-He knows a lot about worms.

Justin Hartman-He just missed fame since Cedarville didn't have a track team.

John Gillespie - He taught the seventh graders how to study.

Wilmott Fischer _ "Amen - Praise the Lord!" Here is a real musician.
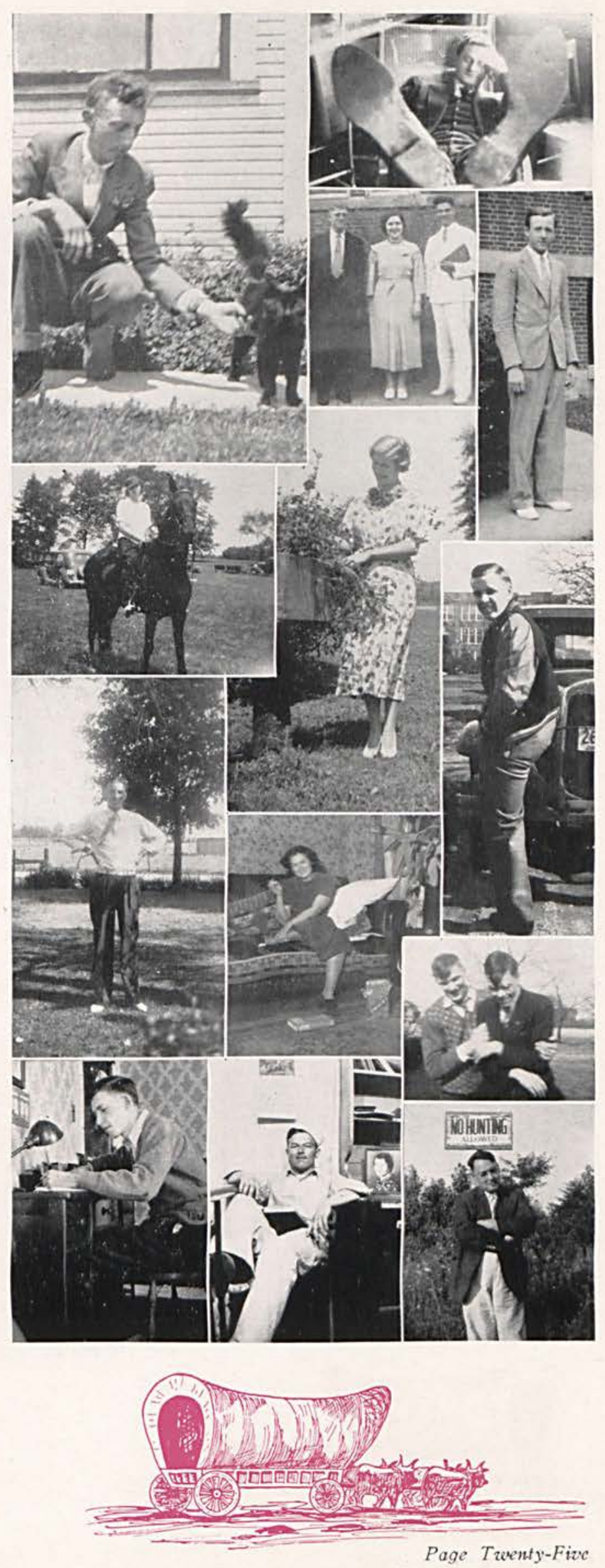

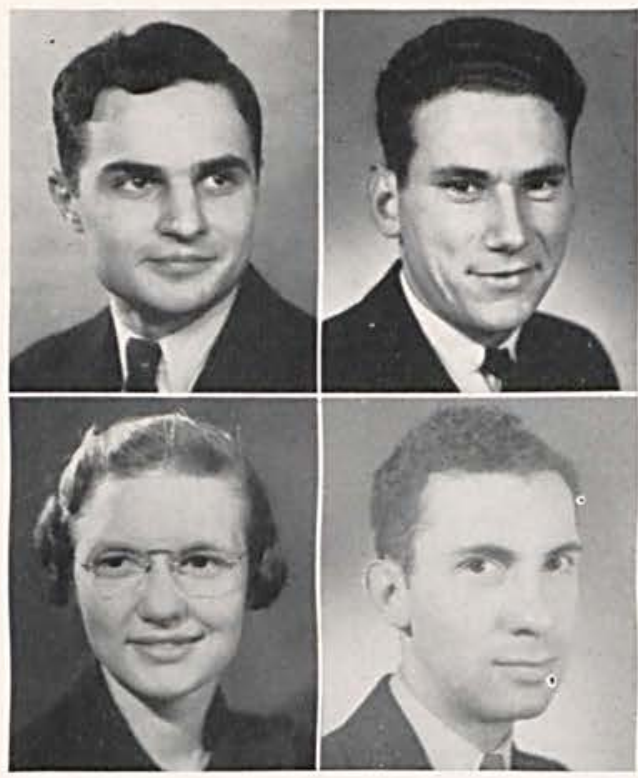

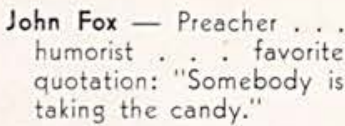

Cecil Thomas - Ball-player ... debater... likes birds (Pidgeons) ... a real student.
Jane Frame-Cheerleade .. Alpha Theta Tau president... wearing a brand new "rock."
JUNIOR

CLASS

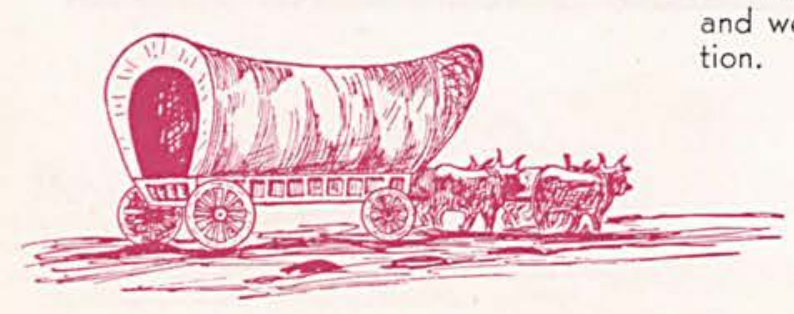

Page Twenty-Six tion.

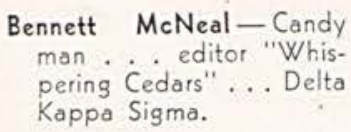

In September, 1935, sixty-five Freshmen (the largest class in the history of the college) entered the side door of Cedarville College by request of the upper-classmen - to start on the long trail toward a diploma. After almost a week of initiation, we organized and settled down to business. We tried to have some feeds but the upper classmen were so interested in them that they nearly always arrived before the freshmen did.

We were represented on the basketball squad by five men Roy Linton and Blutcher Gibson playing on the first team. Our class team won the intra-mural tournament. This helped to make up for our getting dipped in Willow Bend during Freshman Week. Two of our girls, Jacobs and Seamon, were cheerleaders; we also had representatives in debate and basketball.

Our Sophomore year was a busy one for about fifty of our members, for they were going through the ordeal of practice teaching. In the spare time we had we still entered all kinds of extracurricular activities. At the end of basketball season we took time out to win the class tournament again, with cheerleaders Sisson and Tomlinson to help us yell.

Justin Hartman and Roy Linton left us to become Juniors, and at commencement time all the girls except two and several boys left us. Almost all of these people were successful in obtaining teaching positions and we hear that all of them are doing very good work.

As a result of that loss we started our Junior year with only sixteen members. John Fox was elected president of the class: Cecil Thomas, vice-president; Jane Frame, secretary; Bennett McNeal, treasurer. Bennett has had a hard year this year in the candy business, and we appreciate his efforts.

Again we are represented in athletics and other extra-curricular activities, and for the third year we have provided a cheerleader (Jane Frame) bringing our total to five. Since we did not give a class play this year, the big event of our year was the Junior-Senior Banquet held at the Dayton Y. M. C. A.

And now we are looking forward to the last lap of our journey, and we are hoping that next year will bring us safely to our destina. 


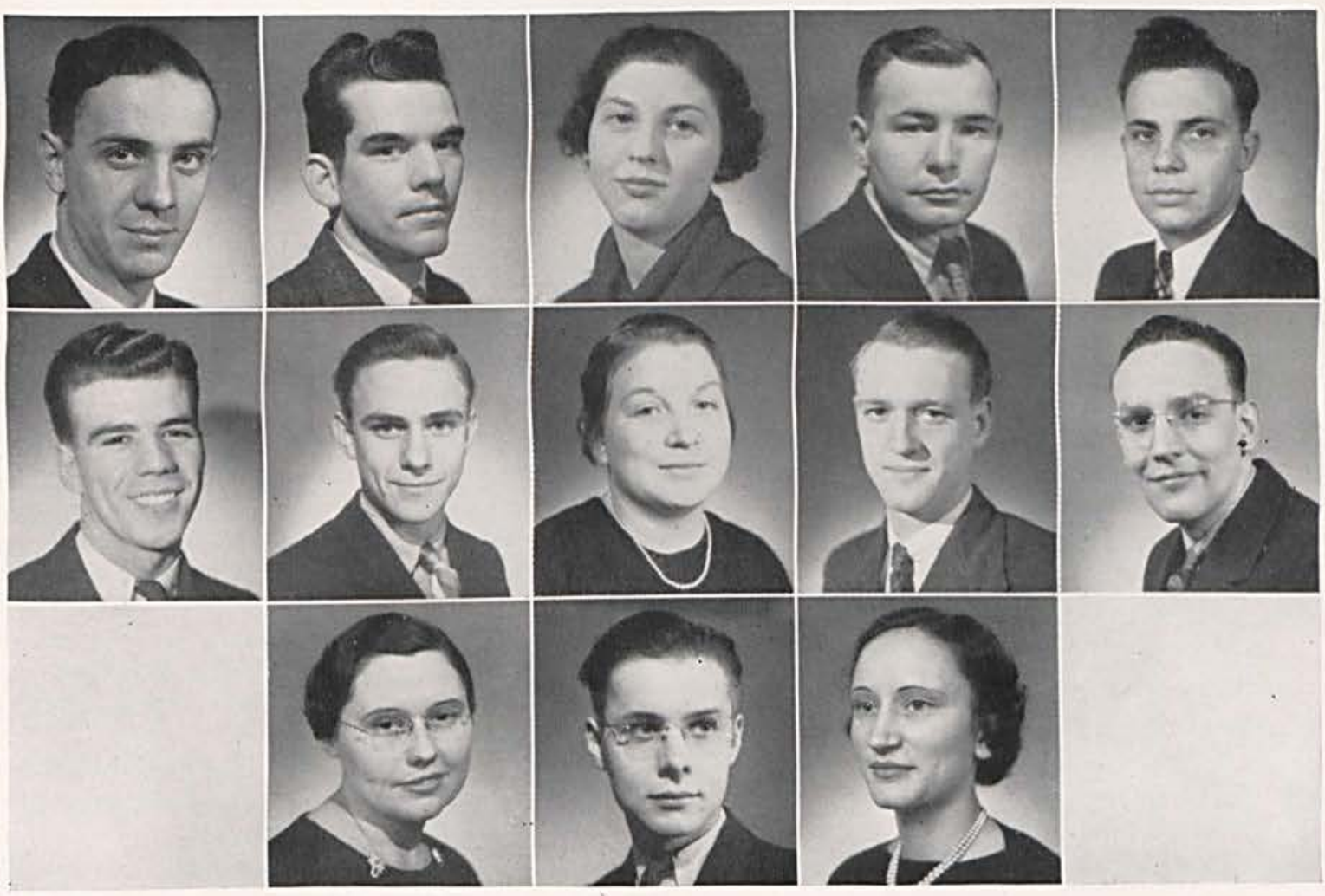

Victor Shaw-Quiet ... Melvin Thompson - Haunts Mary Holway - Jolly ... .

easygoing ... fast driver. McChesney's ... main and does have a good ambition in life-to be a time... came from Ohio big league pitcher. State... teacher in West Jefferson.

Angus Murray-That New Kenneth McNeal-"BlueEnglander.... student of beard" .... cliff-dweller foreign affairs ... the ... curly hair ... broad last of the Murray clan. shoulders.... star guard

Clyde Walker-Blues singer Raymond Sisson-A tenor, Frances Kimble-Hardwork- Noah Sharpe-Library jan- William Loy-Keen dresser ... artist... good lirte .. waiter at the "Blue Goose". . broad smile. a lover, a poet... mathematician and logician... Delta Kappa Sigma. er... violinist... itor ... Delta Kappa Sig. teacher at Fletcher. fast driver of a swell new cat.... man about town

Beatrice McClellam-A sing. Fred Lott-Prophesies do Marthena Smith-Graceful er with an unusual laugh come true- "This 'Lot' for ... Chi Sigma Phi ... sale." Delta Kappa Sig. .... Grecian features. popular among the opposite sex. can be found in the workroom most of the time

ma. shoulders . . star guard 


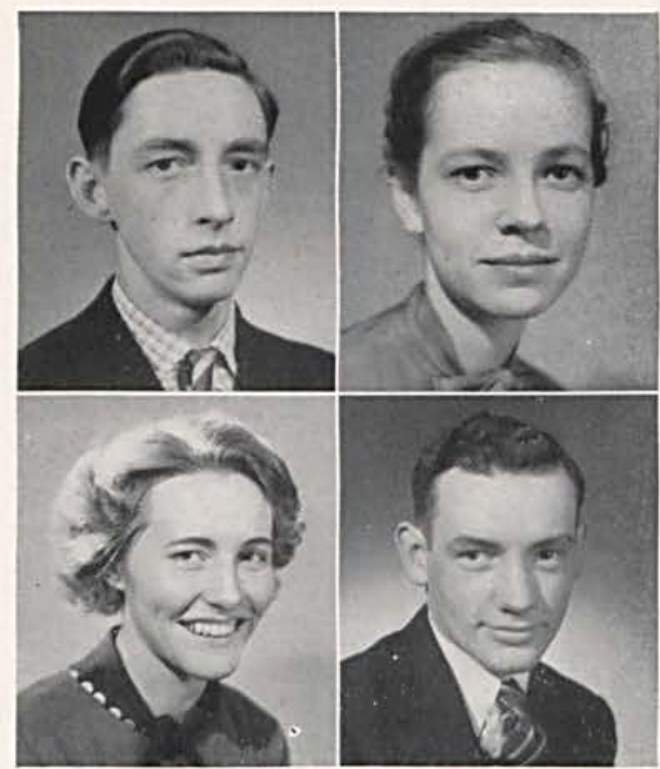

John Peterson

Genevieve Jesson

Catherine Harbaugh

Monroe Pyles

SOPHOMORE

CLASS
In the fall of 1936, we began our short but extremely eventful college careers.

Our first move was to select Eldon Gillespie as our president and in this capacity he effectively guided our activities throughout the term.

We patiently endured the humiliating experiences of Freshman Week. The most easily recalled catastrophe of this ordeal was suffered at Willow Bend, when our boys "only after a titanic struggle," were pulled headlong into its icy waters.

After this annual affair we seemed to get along much better with the upper classmen and by the end of the term had firmly established ourselves as worthy representatives of this fine old school.

This year the majority of our 1936-37 group has returned. This time we chose suave John Peterson as our chairman and he has ably conducted our progress throughout the majority of another college year.

We are particularly proud of our representatives in athletics. In basketball we were fortunate in placing a man on the varsity quintet. Several other Sophomores participated in this sport.

With spring baseball swinging into its first practice sessions, the Sophomores find themselves well represented by many eager applicants for varsity berths. Several of these men stand excellent chances for regular positions.

We have also received favorable recognition in the fields of scholarly endeavor and included within our group are several who rank high in music, dramatics and other worthwhile activities.

We have been happy in pursuing our studies in the delightful atmosphere provided by the college and surrounding community, and by the sincere and altogether wholesome environment created by our beloved faculty. Therefore, it is our desire that during our short stay at Cedarville our presence here will add to, rather than detract from this atmosphere, and that we as a class may profit accordingly. 
Crampton Lott

Helen Crawford

Jessica Taylor

La Verne Whipp

Florence Pidgeon

Ruth Stebbins

Grace Bickett

Bessie Shively

Russell Roberts

Lucille Walton

Virginia Townsley

Royden Johnson

Martha Bartley

Waveline Kelso

Wanda Smith

Bette Allison

Eldon Gillespie

Jane Hampton

Geneva Clemans

Harold Baynard

Pauline Ferguson

Donna Zellar

Edna Anderson

Irene Goodin

Orville Labig

Anna King

Rhea Tavenner

Donald Foulks

Elwood Shaw

Dorothy Bennett

Mary Bingamon

Delbert Tobin
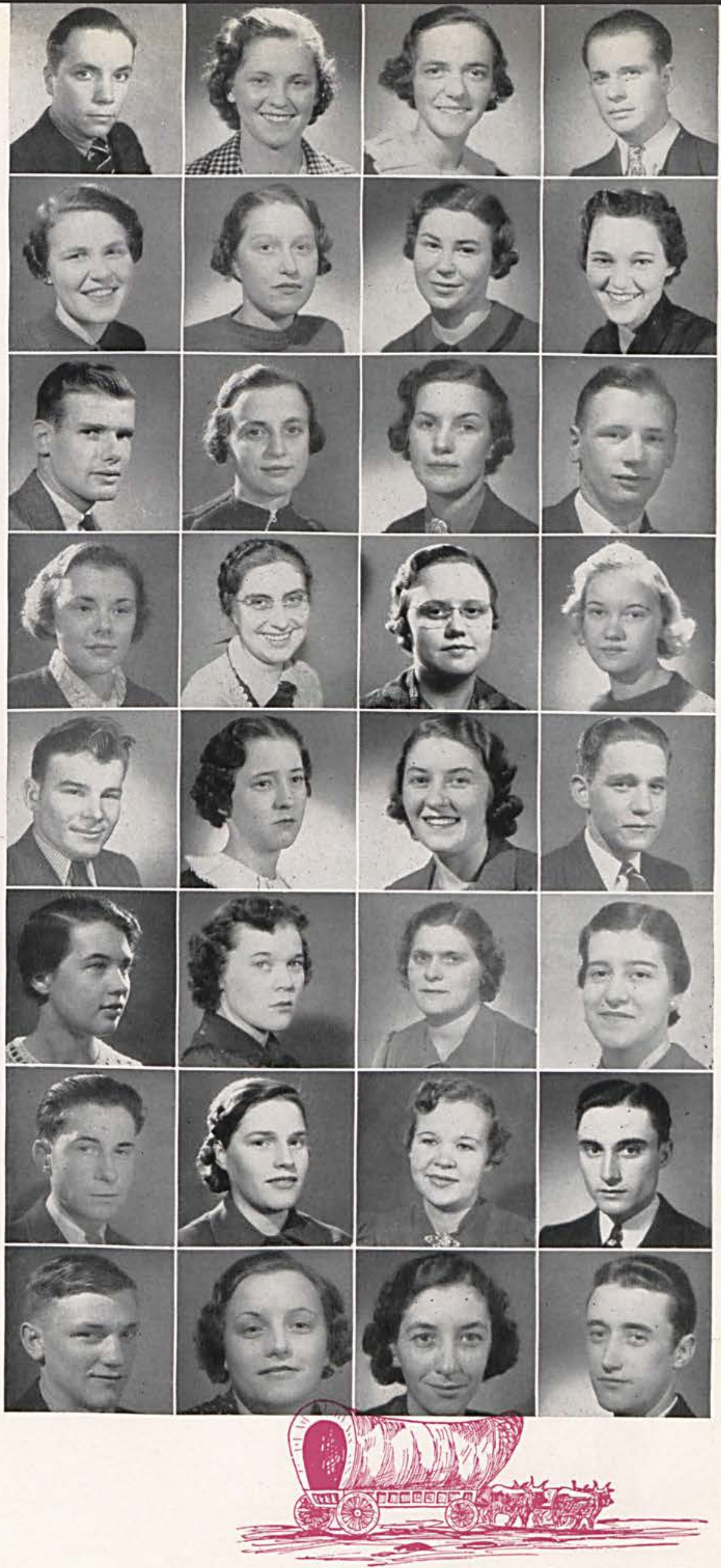

Page Twenty-Nine 


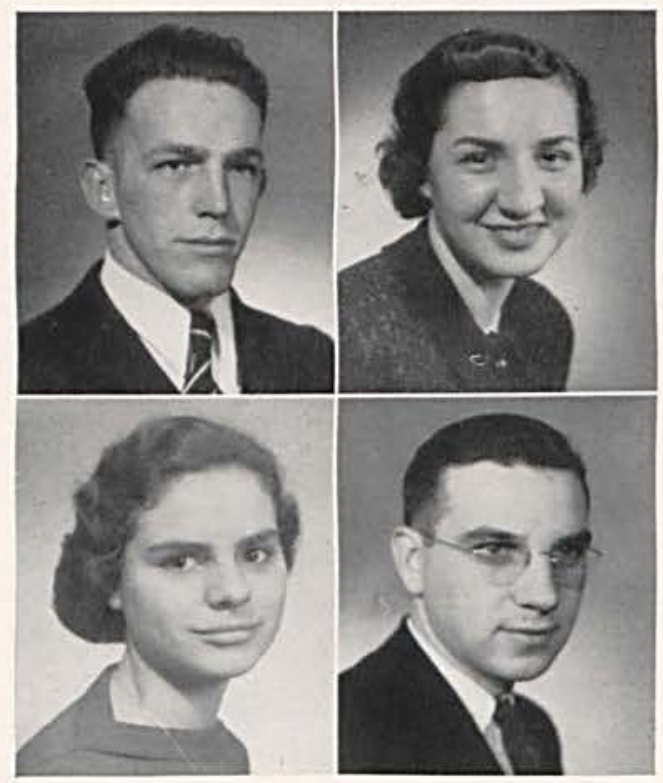

\section{Richard McKnight}

Louise Jacobs

Elisabeth Anderson

Justin Northup

FRESHMAN

CLASS
September 8th, 1937, forty-three Freshmen were registered at Cedarville College. As if these Freshmen were not sufficiently afflicted with homesickness and embarassment, the Sophomores with the aid of the Juniors and Seniors, heaped torment upon affliction. There were white-faced girls seen on the campus in pigtails and boots, carrying pillow slips. There were boys with extra rosy cheeks and red lips, with hairbows and jewelry, carrying waste paper baskets. There were also a lot of upper classmen with the "tummy" ache because they had eaten too many suckers. There were rumors of long rides and walks in the darkness along strange roads. And finally there was a general ducking at Willow Bend; but the Freshmen persevered They knew what they were after and they knew they could get it at Cedarville College as soon as the upper classmen forgot their jealousy.

One day during the first few weeks of school, they met in Dr. McChesney's room to organize. James Anderson, president of the student body, undertook the task of presiding over that quiet group. Getting nominations was like pulling teeth for nobody seemed to know anybody. After much patience was displayed by Mr. Anderson, and a little "loosening up" on the part of the freshmen, the following officers were elected: Richard McKnight, president; Louise Jacobs, vice-president; Elizabeth Anderson, secretary; Justin Northrup, treasurer; Mary Jean Townsley, news reporter; and Doris Ramsey, student council representative.

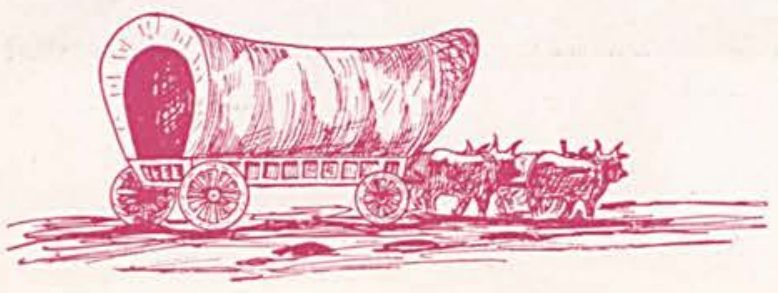

Page Thirly 
Merieum Foulk

Helen Mossbarger

Eugene Kavanaugh Opal Seaman

Ruth Booher

Velma Henderson

Rachel Harriman

Arthur Geake

Elinor Young

Margaret Olinger

Marie Collins

Charlotte Turner

Harold Thomas

Jean Elliott

Mary Edgington

Ruth Stoddard

Catherine Overholser

Clayton Wiseman

Marcella Tobin

Orena Marshall

Junia Creswell

Wanda Griffith

Neil Hartman

Florence Pidgeon

Louise Cosler

Mary Jean Townsley

Beatrice Gray

William Lott

Doris Ramsey

Clarabelle Ankeney

Barbara Carter

Dorothy Kennon

Fred Vermillion

Helen Chitty

Betty Rowe

Rosenni Guthrie

Ted James

Rosalyn Guthrie
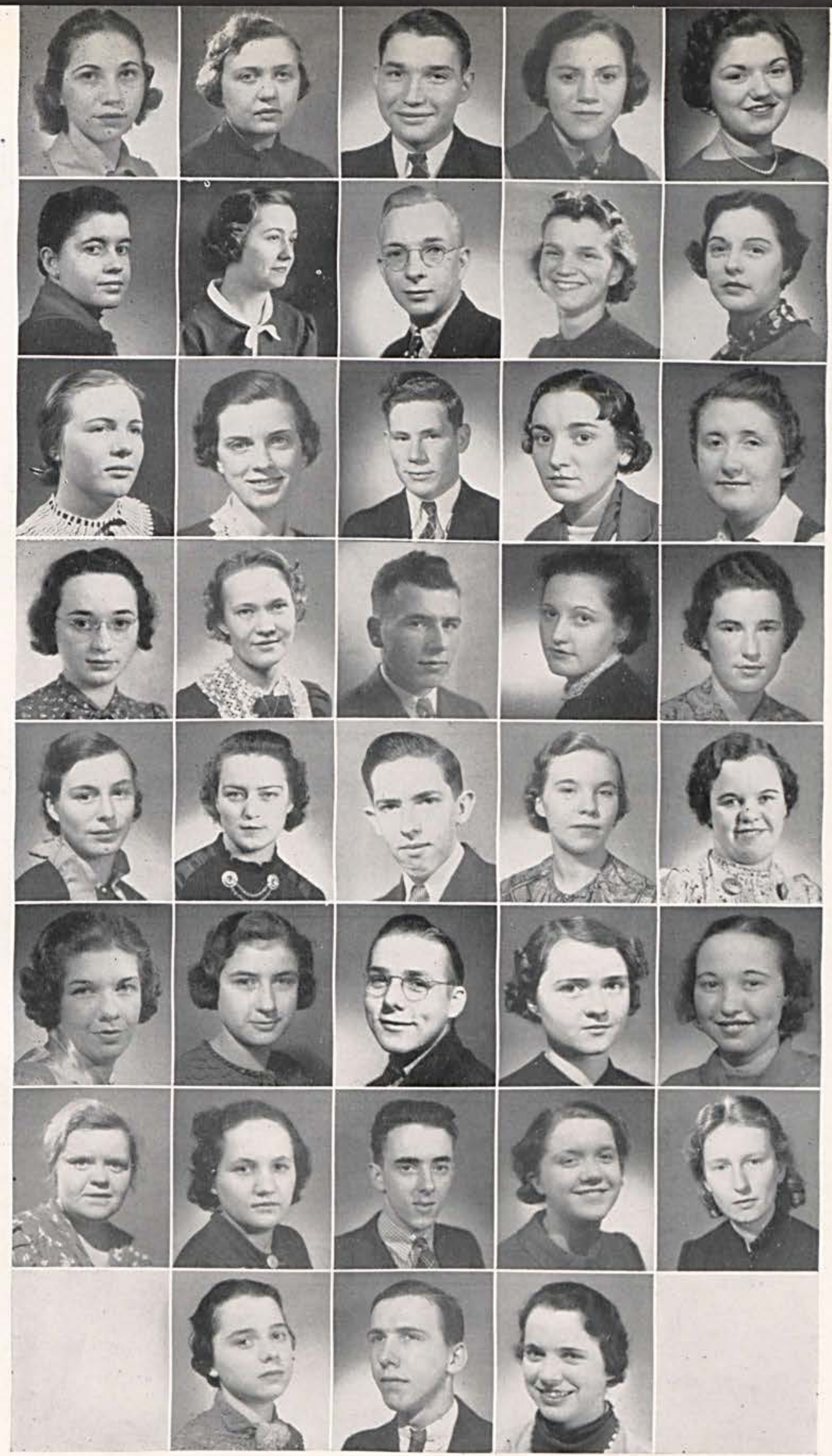

THE 1938 CEDRUS 

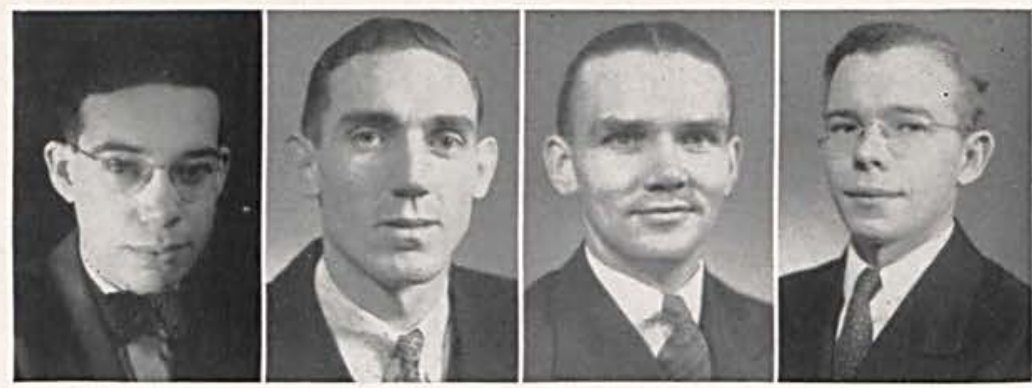

\section{SPECIAL STUDENTS}

There were four students enrolled in the college this year as postgraduates. Everett Keener attended Cedarville College only the first semester, working on his A. B. degree. Mr. Keener is a graduate of the Cumberland University Law School at Lebanon, Tennessee. He is expecting to return to Cedarville College in the future to complete his course. The other special students, Mr. Frank Wiley, Mr. John Taylor, and Mr. Robert McKibben are enrolled in the Cedarville Seminary.

THE

\section{SEMINARY}

Under the able instruction of Dr. W. R. McChesney and Dr. F. A. Jurkat, the three students of the Cedarville Seminary are nearing the close of the first year of their work. The three men are Mr. John Taylor, who comes to us from India, where he lived for the first sixteen years of his life with his parents, Mr. and Mrs. John C. Taylor, missionaries of the Reformed Presbyterian Church at Boorkee, India. Coming to America he finished the last two years of his high school course at Stafford, Kansas. His college work was taken at Muskingum College, New Concord, Ohio, where he was active in the Christian and athletic activities of the college.

Mr. Robert McKibben, son of The Reverend Mr. and Mrs. E. G. McKibben of the United Presbyterian Church, was born at Fairfield, lowa. He has received his schooling in a number of different states. His high school work was taken at Seaman, Ohio, and his college work at Marysville, Tennessee. He has been active in the religious organizations of the college and his home church.

Mr. Frank Wiley of Wapello, lowa, received all of his pre-college work in his home state, going to college at Geneva at Beaver Falls, Pennsylvania. He taught for a number of years at Frenchburg, Kentucky.

The Seminary was organized under the capable leadership of Mr. Taylor, who was elected president. The members of the Seminary are also members of the religious organization, "The Gospel Team," of Cedarville College. 


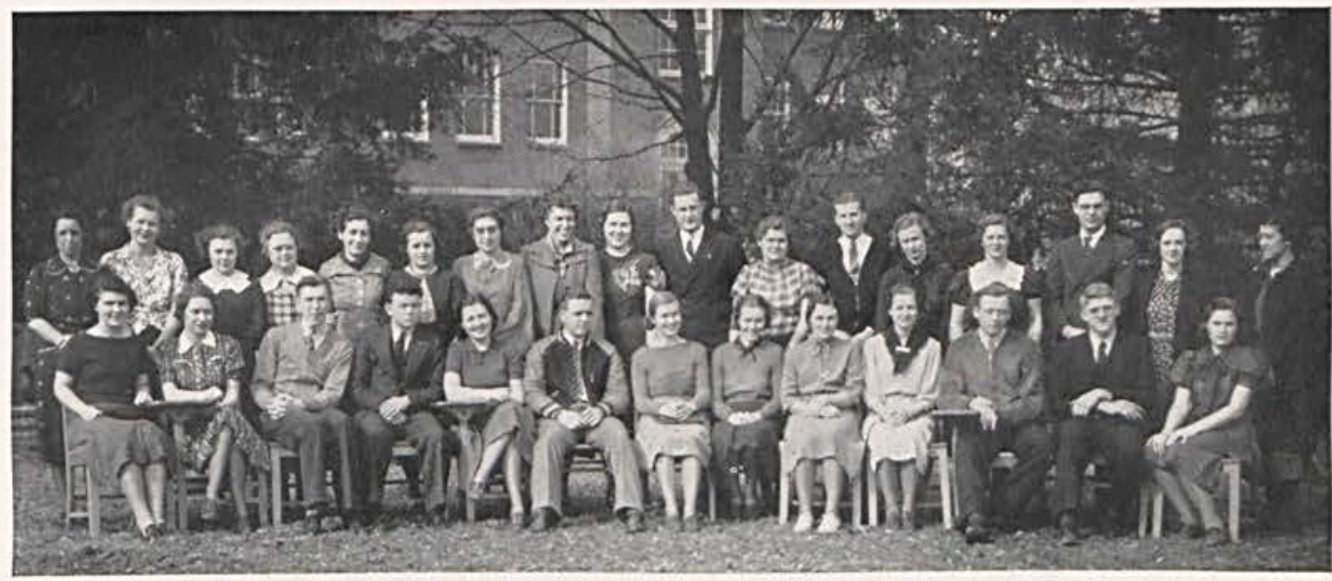

Ist Row: F. Pidgeon, R. Stebbins, J. Hartman, J. Gillespie, M. Johnston, R. Linton, R. Creswell, R. Harbaugh, B. Shively, G. Jesson, K. Sanderson, H. Shaw, A. King. 2nd Row: Mrs. Kling, R. Tavenner, M. Bartly, W. Smith, M. Bingamon, D. Bennett, W. Kelso, B. Shaw, M. Bryant, H. Swaim, E. Anderson, H. Cummings, L. Walton, H. Crawford, J. Anderson, J. Taylor, I. Goodin.

During the past year those who are in the education department have been endeavoring to reach the goal of efficient teaching. Good teaching is by no means an easy accomplishment as many have found out, but the high aim of efficient teaching is attained only by much perseverance, work, and whole-hearted interest. It was with fear and trembling that many took over the actual duties as teachers but this feeling soon disappeared as they became accustomed to the situation and grasped the true spirit of their work.

The practice teachers sincerely feel that they owe much to their instructors and critic teachers for their guidance and helpful criticism, which aided them to correct many of their mistakes as beginners.

Mr. Hostetler, as head of the education department, has by his untiring efforts, maintained the high and worthy standards of the teaching profession.

\section{PRACTICE}

\section{TEACHERS}

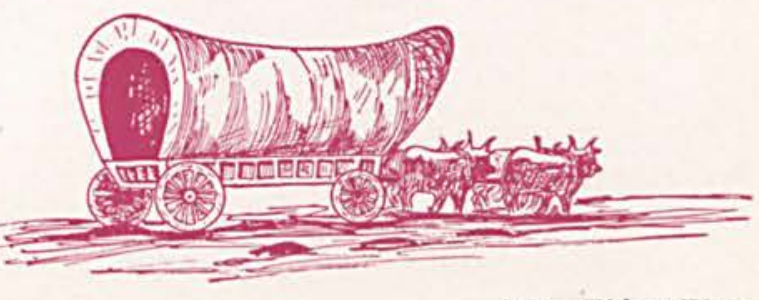

Page Thirty-Three 


\section{Organizations}

Dr the frontier progress came through cooperation. Each had hís own tagk but algo contributed to the common welfare.

Che organizationg of Cedarville College work together for their mutual debelopment = always striving to belp both the college and the indivioual student. 


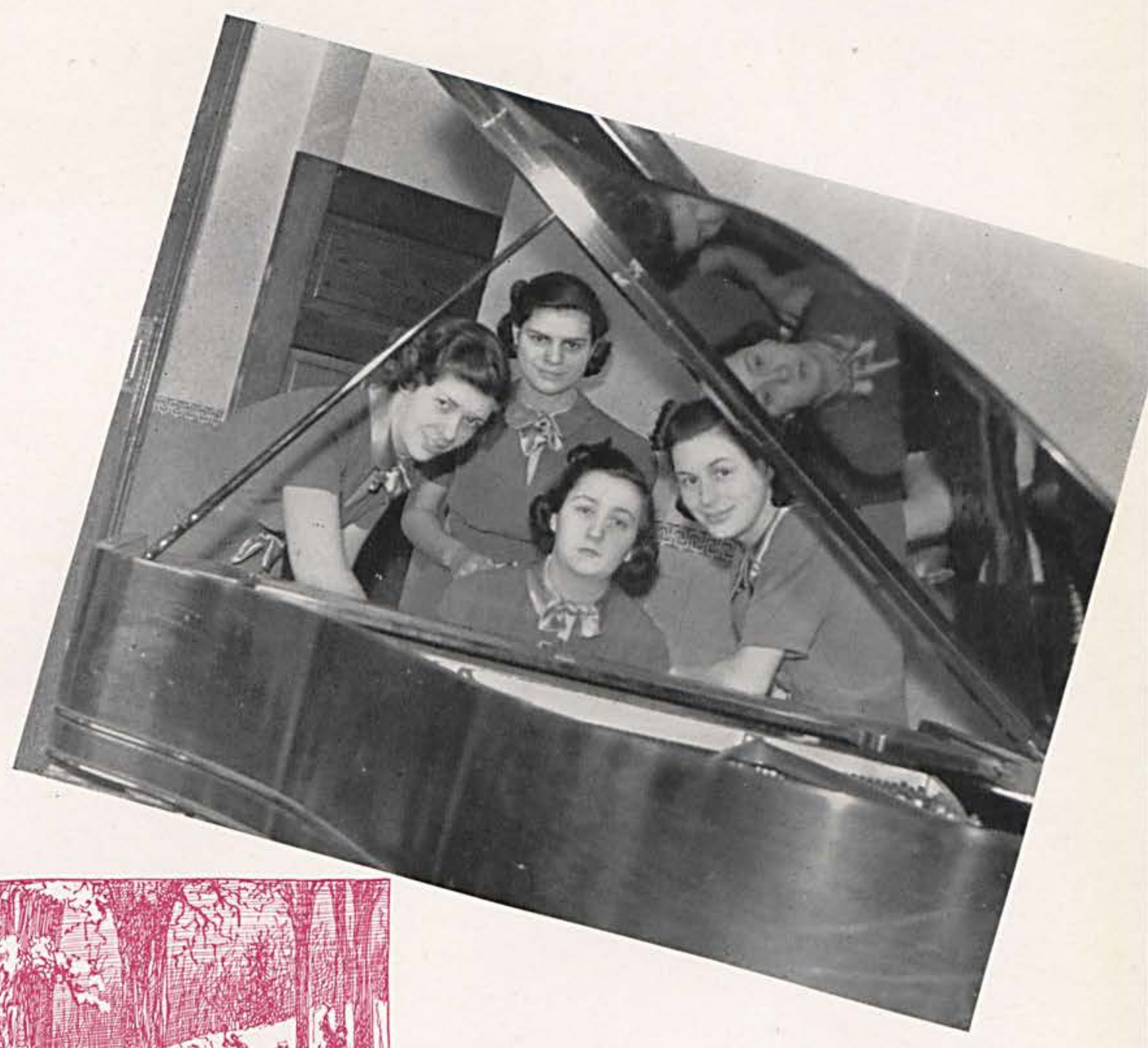

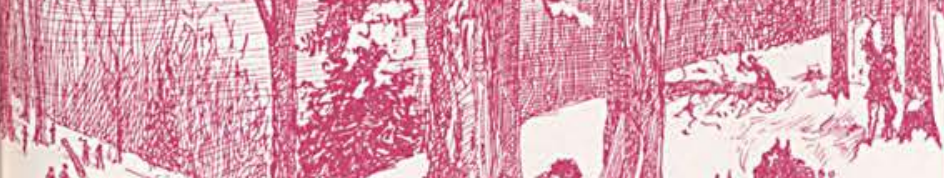
$4 w^{4}$

\% ard.

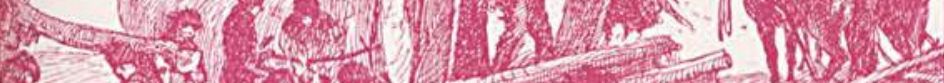

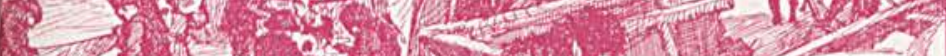
(a) $e_{0}$.

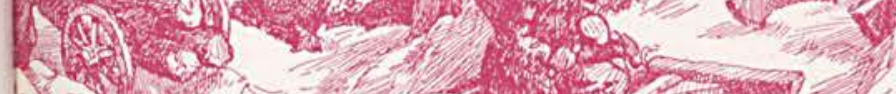
N-W

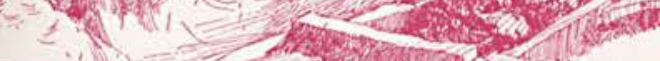


Sitting: Doris Ramsey, Mary Johnston, Ray Linton, John Fox, Russel Roberts, Betty Shaw.

Standing: Noah Sharpe, John Peterson, James Anderson, Richard Macknight.

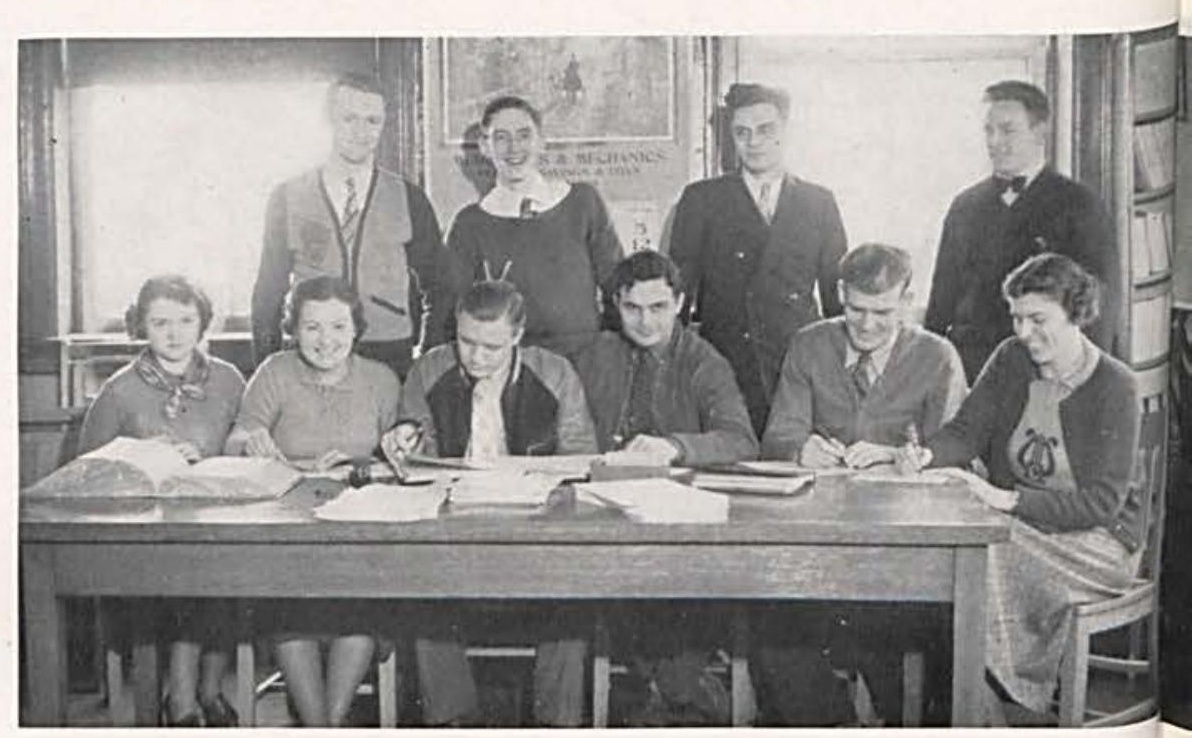

\section{STUDENT} COUNCIL

The Student Council of Cedarville College consists of the President of the College, the College Deans, the officers of the student body, the presidents and one other member from each class.

The Council again sponsored our weekly school paper the "Whispering Cedars." It has also cooperated with the Business Manager, Mr. J. L. Dorst, in securing the names of high school seniors and other prospective students.

The Council consists of the following members: W. R. McChesney, President of the College; J. L. Dorst, Business Manager; H. Santmyer, Dean of Women; C. W. Steele, Dean of Men; J. Anderson, Pres. of the Student Body; M. Johnston, Sec. of Student Body: R. Linton and B. Shaw, president and representative of the Senior Class; J. Fox and N. Sharpe, President and representative of the Junior Class; J. Peterson and R. Roberts, President and representative of the Sophomore Class. 
Sitting: Mary Jean Townsley, Marie Collins, Roy Linton, Harold Shaw, Martha Bryant, Betty Shaw, Jessica Taylor, Pauline Ferguson.

Standing: Ray Sisson, Clyde Walker, Bennett McNeal.

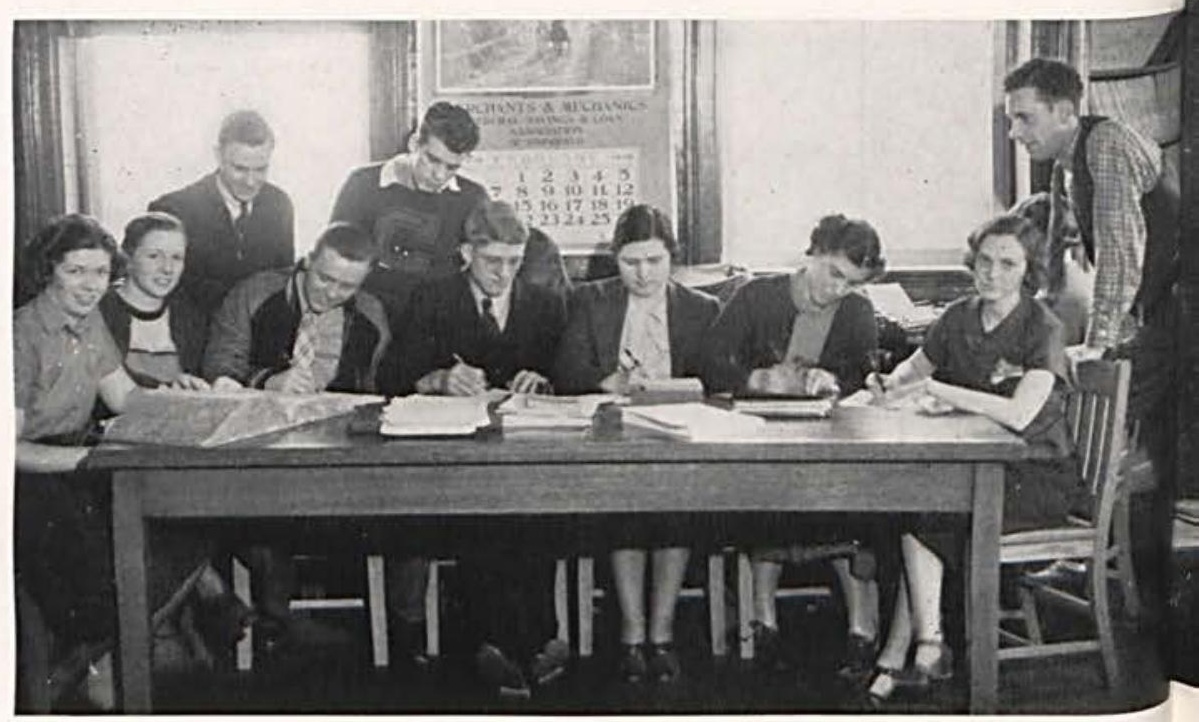

\section{WHISPERING CEDARS}

The Whispering Cedars was very ably edited by Bennett McNeal. His ceaseless effort was the chief reason the Whispering Cedars reached its height of popularity. Every Friday at noon there was a mad rush of the students to get their weekly issue of the college paper. We were always certain we would see such names as Harold Shaw, Eugene Kavanaugh, and Ted James, on the scandal page because of their various romantic escapades.

The editorials were always timely, practical and interesting. Each week articles by the students were published on subjects that were of interest to all.

Assisting the editor in assembling the paper were Roy Linton, Business Manager: Pauline Ferguson and Marie Collins, typists. The success of this year's paper has resulted from the cooperation of members of the student body with the staff in helping to make each issue interesting and helpful.

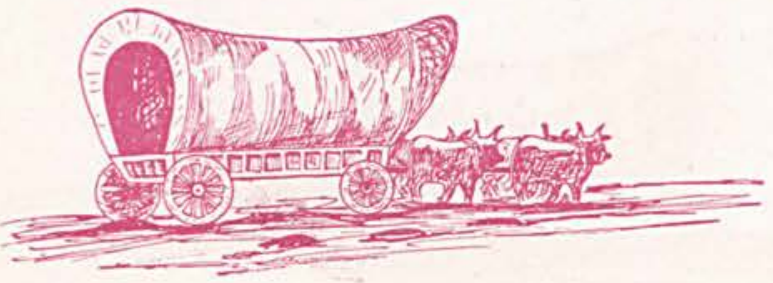

Paxje Thirty-Eight 


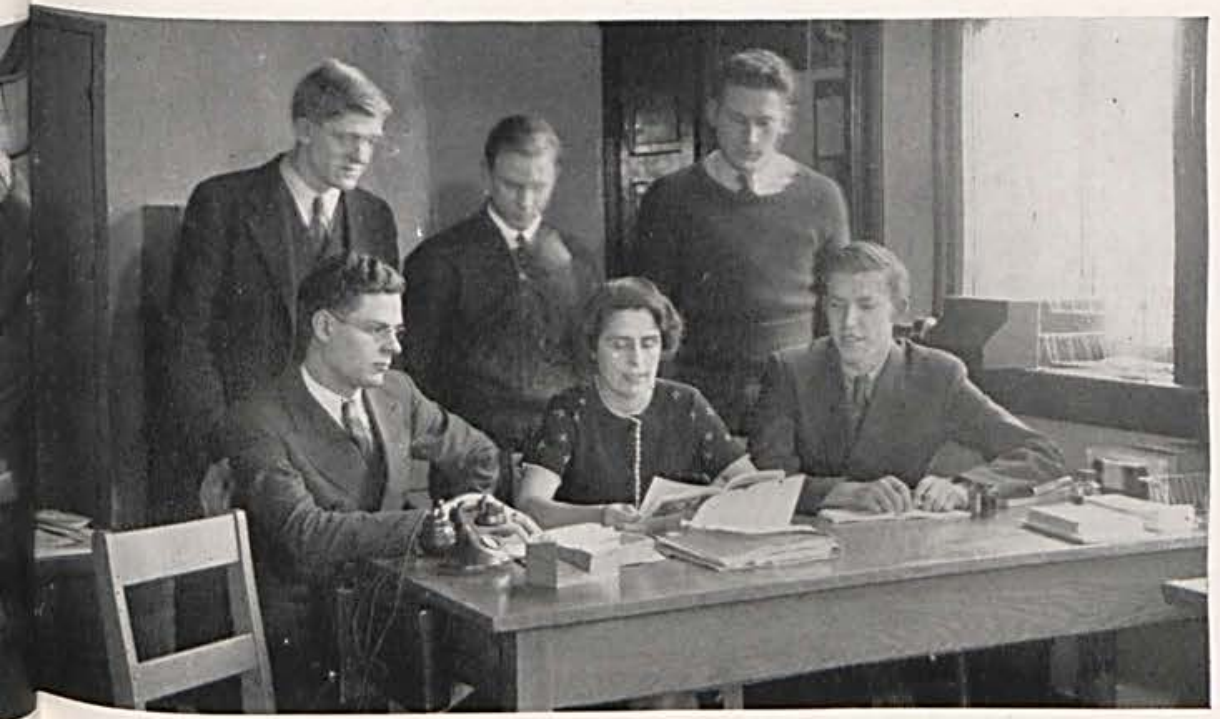

Sitting: James Anderson, Mrs. Ault, Justin Hartman.

Standing: Harold Shaw, Raymond Sisson, Cecil Thomas.

\section{DEBATE}

The debate teams of Cedarville College have had a very successful season this year. The affirmative team consisted of Ray Sisson, Cecil Thomas and Harold Shaw. The negative team was composed of James Anderson and Justin Hartman. The coach of the debate squad of Cedarville College was Mrs. Marguerite C. Ault, who deserves much credit for her persistence and patience in molding a forensic team.

The first debate was with Rio Grande College, the teams splitting the decision. Dr. Breese of Wittenberg College, head of the Department of Speech, judged the debates. Later in the season both teams met Wilberforce University in a non-decision debate.

Then the teams went to Cincinnati where the negative team debated the Cincinnati Bible Seminary. The next stop was at Dayton University at Dayton. The negative team won by a decision of the Dayton U. Public Speaking classes. The affirmative debate was non-decision.

The final stop was at Manchester, Indiana, where the debate tournament was held. Cedarville had to go to Huntington because of crowded conditions at Manchester College. The teams considered the trip a success, having won 4 out of 12 debates.

The question for debate this year was "Resolved that the National Labor Relations Board should be empowered to enforce arbitration of all industrial disputes." 


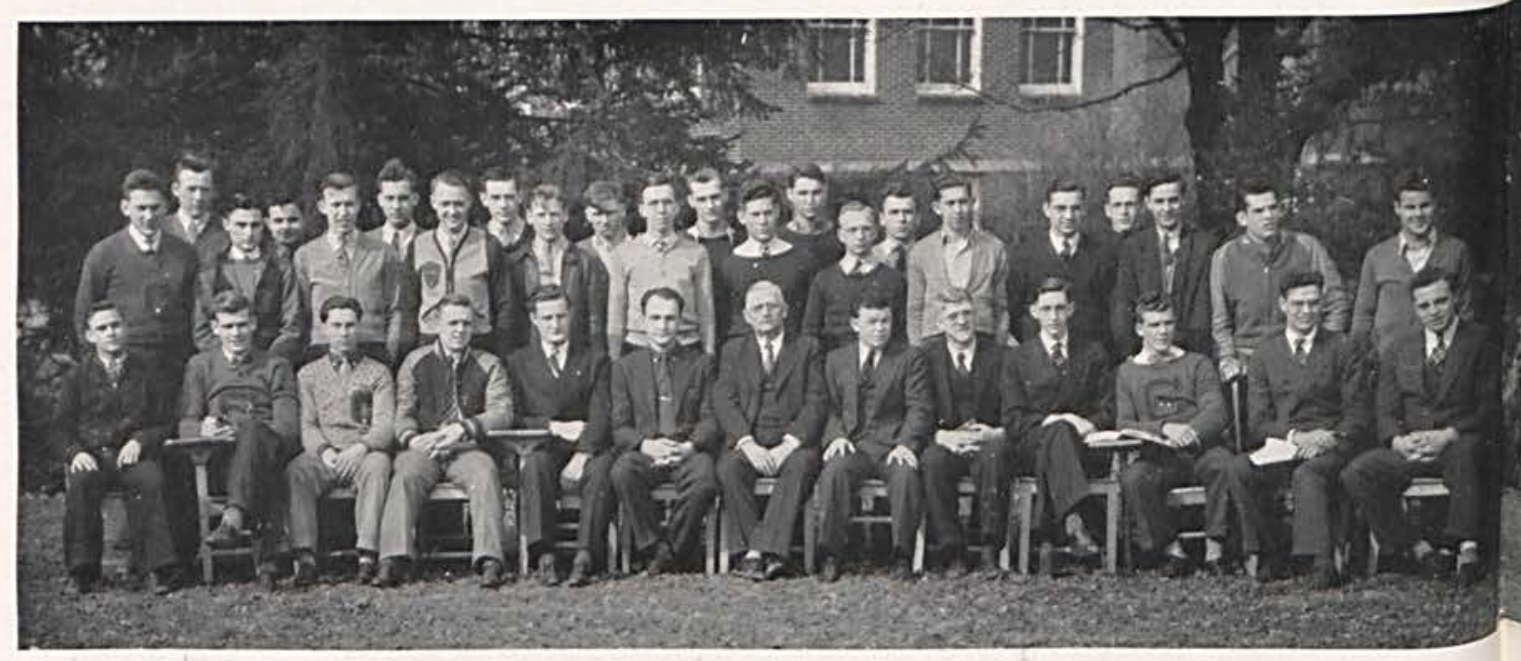

Sitting: R. Sisson, R. Roberts, O. Labig, R. Linton, H. Swaim, J. W. Ault, C. W. Steele, J. Gillespie, H. Shaw, J. Peterson, C. Walker, J. Anderson, K. McNeal. Standing: K. Sanderson, D. Foulks, J. Fox. J. Hartman, B. McNeal, N. Sharpe, M. Pyles, R. Johnson, E. Shaw, T. James, R. Reed, H. Thomas, E. Kavanaugh, A. Geake, C. Wiseman, N. Hartman, J. Northrup, R. Macknight, V. Shaw, M. Thompson, J. Jackson.

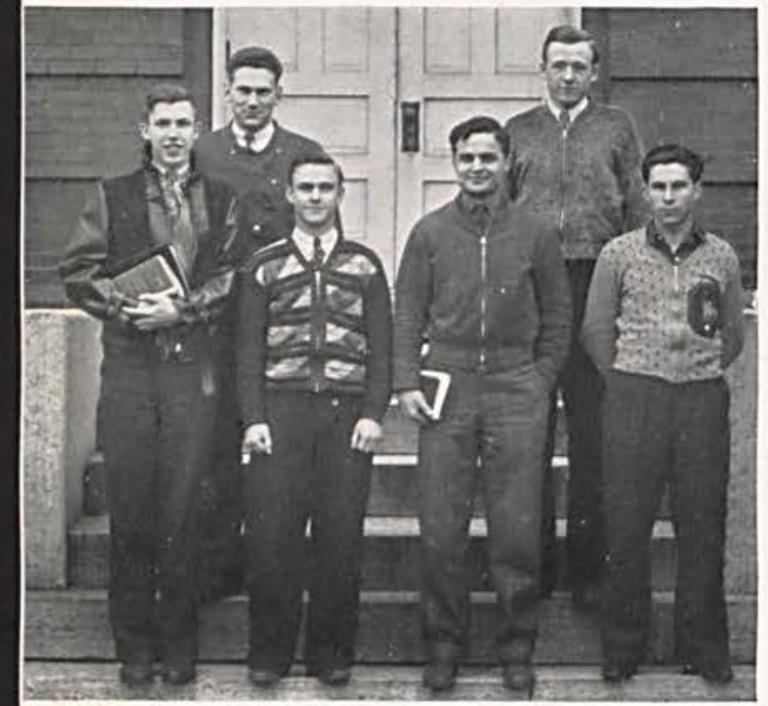

Left to Right: Justin Hartman, Cecil Thomas, Raymond Sisson, John Fox, Kenneth Sanderson, Orval Labig.

\section{Y.M.C. A.}

The Young Men's Christian Association gives every young man at Cedarville College an opportunity for fellowship and service. Each Wednesday morning a program of worship, instruction, and entertainment is presented.

Some of the principal speakers and their topics of the year have been:

Rev. Bob Copeland, Pastor of U. B. Church at Brookville"Founding a Christian Home."

Mr. Walter Edwards, General Secretary of Y. M. C. A. of Sprinģfield-"Religion's Value in Living.

Dr. Alexander, Assistant to President of Antioch College"Horace Mann."

J. Reed Miller, Speaker at Day of Prayer for Colleges last year-"The Certainty of God."

Prof. A. J. Hostetler, Professor at Cedarville College-"The Educated Man."

Rev. C. C. Hankins, Chaplain at O. S. \& S. O. Home"The Philosophy of Life."

Rev. R. J. Turreil, Pastor of Bethlehem M. E. Church of Cincinnati- "Spiritual Preparation for War."

Dr. Samuel Grothwell-"Tinkers and Thinkers."

Dr. T. Z. Koo of Shanghai China-"'The Chinese Situation in the Orient."

Mr. Cornwell, Chief of Police of Xenia-"Police."

Mr. Weaver, President of Columbus Gas \& Fuel Co.-"The Pursuit of Happiness."

THE 1938 CEDRUS

Page Forty 


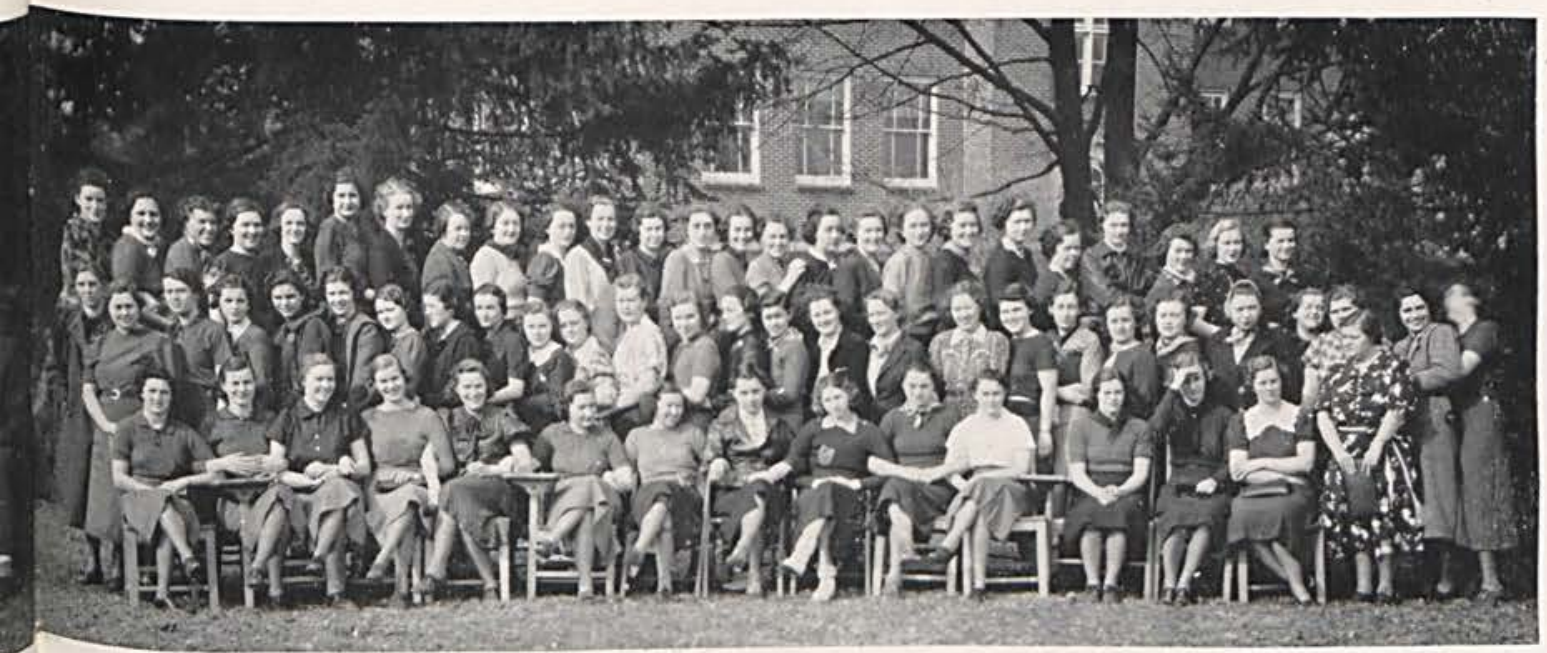

Ist Row: M. Olinger, J. Creswell, M. Collins, R. Creswell, A. King, L. Jacobs, C. Ankeney, R. Guthrie, M. Foulk, R. Guthrie, B. Rosher, O. Seamon, L. Walton, H. Crawford, B. Carter, Mrs. Ault, M. Johnston. 2nd Row: Miss Basore, B. McClellan, P. Ferguson, C. Turner, E. Anderson, M. J. Townsley, D. Ramsey,

I. Goodwin, J. Elliott, M. Bartley, W. Smith, R. Tavenner, F. Ferguson, W'. Griffith, V. Henderson, M. Tobin, C. Overholser, R. Stebbins, F. Pidgeon, M. Bingarnon, D. Bennett, H. Mossbarger, M. Williams, H. Chitty, E. Anderson. 3rd Row: O. Marshal!, D. Kennon, B. Shaw, M. Bryant, J. Taylor, B. Gray, B. Rowe, M. McKibben, M. Edginton, R. Stoddard, G. Jesson, G. Bickett, W. Kelso, C. Harbaugh, B. Shively, R. Harriman, V. Townsley, M. Smith, G. Clemans, R. Booher, L. Cosler, J. Frame,

D. Zeller, B. Allison, E. Young.

\section{Y.W.C.A.}

The Y.W. C. A. has flourished unusually well this year. The membership has been large and the meetings well attended.

The first event of the year was the Y. W. Tea held at the home of Jane Frame. Here all the girls had a chance to get better acquainted.

In November the annual Committal Service, in memory of Frances McChesney, was held at the Presbyterian Church. At this service the girls were officially taken into the $Y$. W. This service is very beautiful and impressive. It was efficiently led by our President, Mary Johnston.

In December the "Secret Pal" party was held at the home of Mildred McKibben. The party was a success and everyone was pleased as well as surprised to find out who her "Secret Pal" was.

Our "Mad-Hatter" party proved to be one of the hilarious parties of the year. Everyone wore a "mad-hat" creation and a prize was awarded the best hat. Games of all descriptions were played until everyone was out of breath. Some of the students modelled their clothes for the style show which was a noted success. To climax the evening we girls tried to give the "Mock Wedding." Due to the kidnapping of the bride (Mary Johnston), the groom (Martha Bryant) was left alone and the preacher (Betty Shaw) was left without a fee.

The last event of the year was the Mother-Daughter Banquet. The daughters prepared a delicious banquet for their mothers. Everyone enjoyed meeting the mothers and all had a grand time.

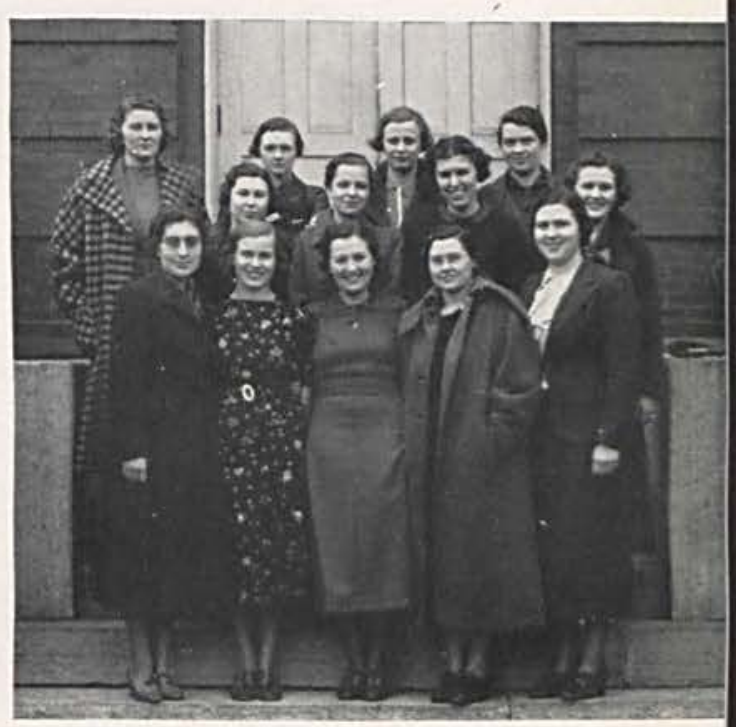

First Row: Wavealine Kelso, Rachel Creswell, Mary Johnston, Beatrice McClellan. Martha Bryant.

Second Row: Grace Bickett, Genevieve Jesson, Betty Shaw, Marcella Tobin.

Third Row: Geneva Clemans, Jane Frame Lucille Walton, Pauline Ferguson.

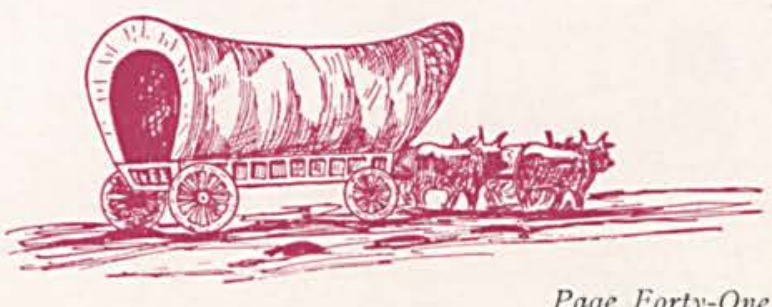

Page Forty-One 
First Row: Arthur Geake, Roy Linton, John Fox.

Second Row: Glenna Basore, Betty Shaw, Helen Chitty, Helen Mossbarger, Louise Cosler.

Third Row: Richard Macknight, John Taylor, Orval Labig, LaVerne Whipp, Beatrice McClellan, Ruth Booher, Cecil Thomas. Mary Johnston.

Fourth Row: Elwood Shaw, Roydon Johnson, Lee Spahr, Harold Thomas, Bennett $\mathrm{McNeal}$, Justin Northup, Kenneth $\mathrm{McNeal}$.

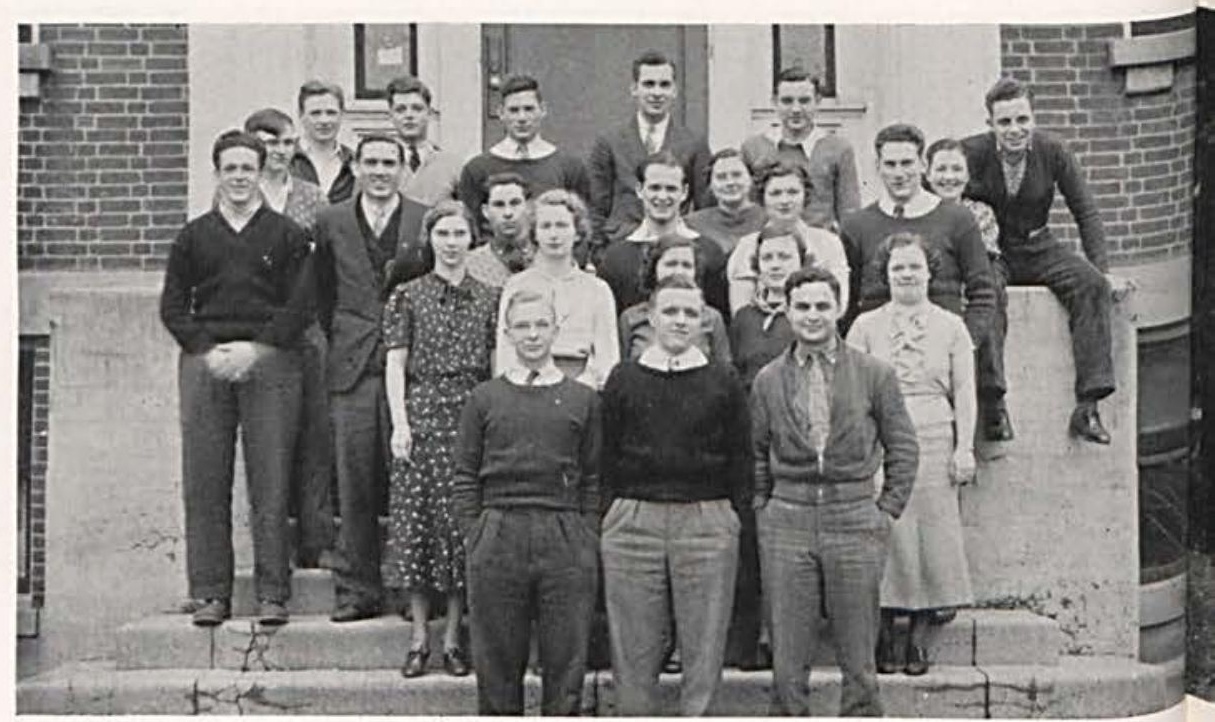

\section{BOARDING CLUB}

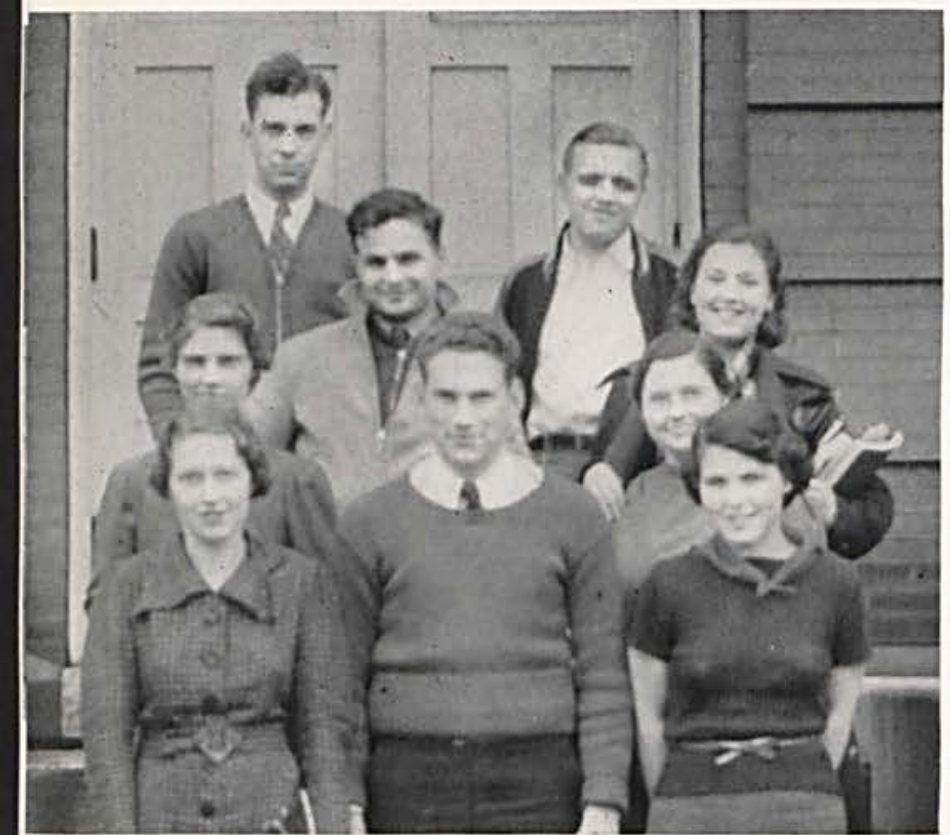

First Row: Ruth Stebbins, Cecil Thomas, Florence Pidgeon.

Second Row: Glenna Basore, John Fox, Beatrice McClellan.

Third Row: Bennett McNeal, Roy Linton, Mary Johnston.

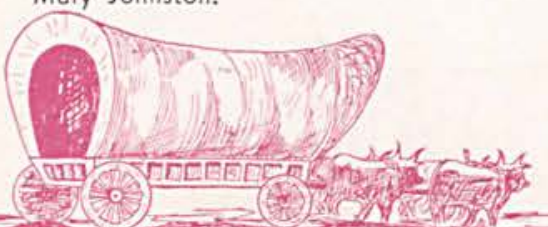

A College Boarding Club, organized by the students, has been successfully maintained this semester. Roy Linton was elected Steward and President; John Fox, Vice-President; Florence Pidgeon, Secretary-Treasurer, Mary Johnston, and Bennett McNeal, assisted by Mrs. Morton, menu committee; Cecil Thomas, Ruth Stebbins, and Beatrice McClellan, social and publicity committee.

The members purchased games which were enjoyed before and after the two daily meals.

The Club, organized on a cooperative basis, has served delicious meals at a very reasonable cost.

Page Forty-Two 


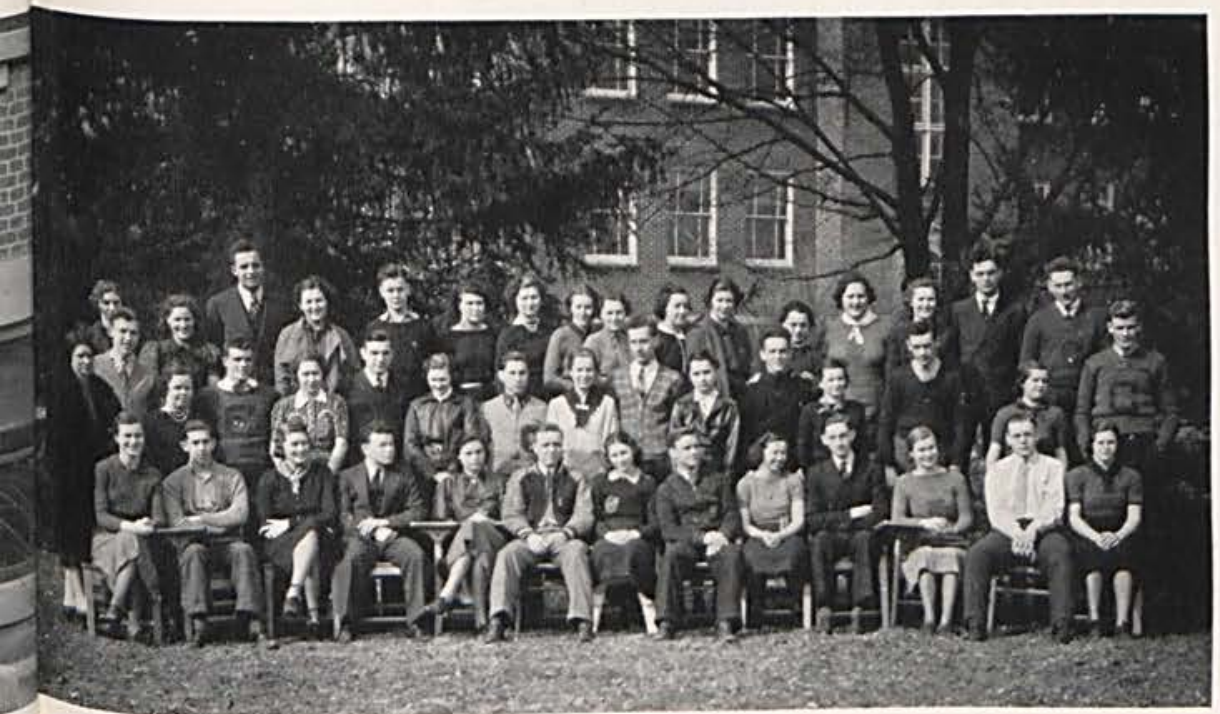

First Row: Junia Creswell, Neil Hartman, Geneva Clemens, John Gillespie, Elizabeth Anderson, Roy Linton, Merieum Foulk Ray Sisson, Clara Belle Ankeney, John Peterson, Rachel Creswell, William Lott. Opal Seamon.

Second Row: Miss Santmyer, Justin Hartman, Louise Cosler, Clyde Walker, Ruth Stebbins, Justin Northup, Jane Frame, Orval Labig, Genevieve Jesson, Bennett $\mathrm{McNeal}$, Rosenni Guthrie, Richard Macknight, Elinor Young, Monroe Pyles, Helen Chitty, Russel Roberts.

Third Row: Miss Basore, Anna King, Kenneth McNeal, Mary Johnston, Fred Lott, Florence Pidgeon, Ruth Booher, Kathryn Har baugh, Bessie Shively, Rachel Harriman, Mary Jean Townsley, Rosalyn Guthrie.

\section{DRAMATIC CLUB}

To start the year with a bang (-and what a bang!) the club sponsored a hay ride. With a truck packed with pleasure seekers we drove from Xenia to Yellow Springs, then on to Springfield where Benny McNeal (trying to drive with one hand-so they say) nearly landed us all in the police station. Some weeks later Benny received an itemized bill of \$112.50 for lamp post fixtures.

This year we have tried to create more interest in the meetings by presenting a series of one act plays, among which were: The Wedding Present, The Florist Shop. The Tale of a Shirt, Girls Will Be Girls, Lovely Lady, the court scene from The Merchant of Venice, and You Can Never Tell What a Woman Will Do. These plays were directed and acted by members of the club under the supervision of Miss Basore and Miss Santmyer.

The Club has also staged some three act plays sponsored by various organizations. The climax of the Dramatic Club's efforts was The Late Christopher Bean, a popular Broadway hit and screen play.

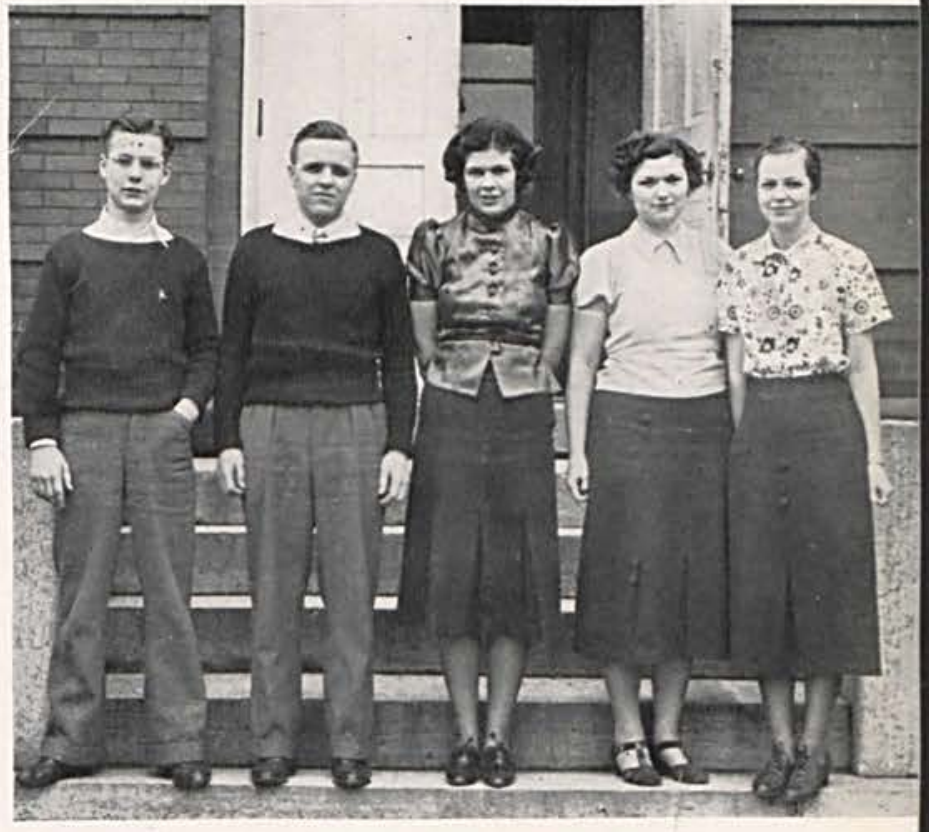

DRAMATIC CLUB OFFICERS

Fred Lott, Roy Linton, Mary Jean Townsley Ruth Booher, Genevieve Jesson. 


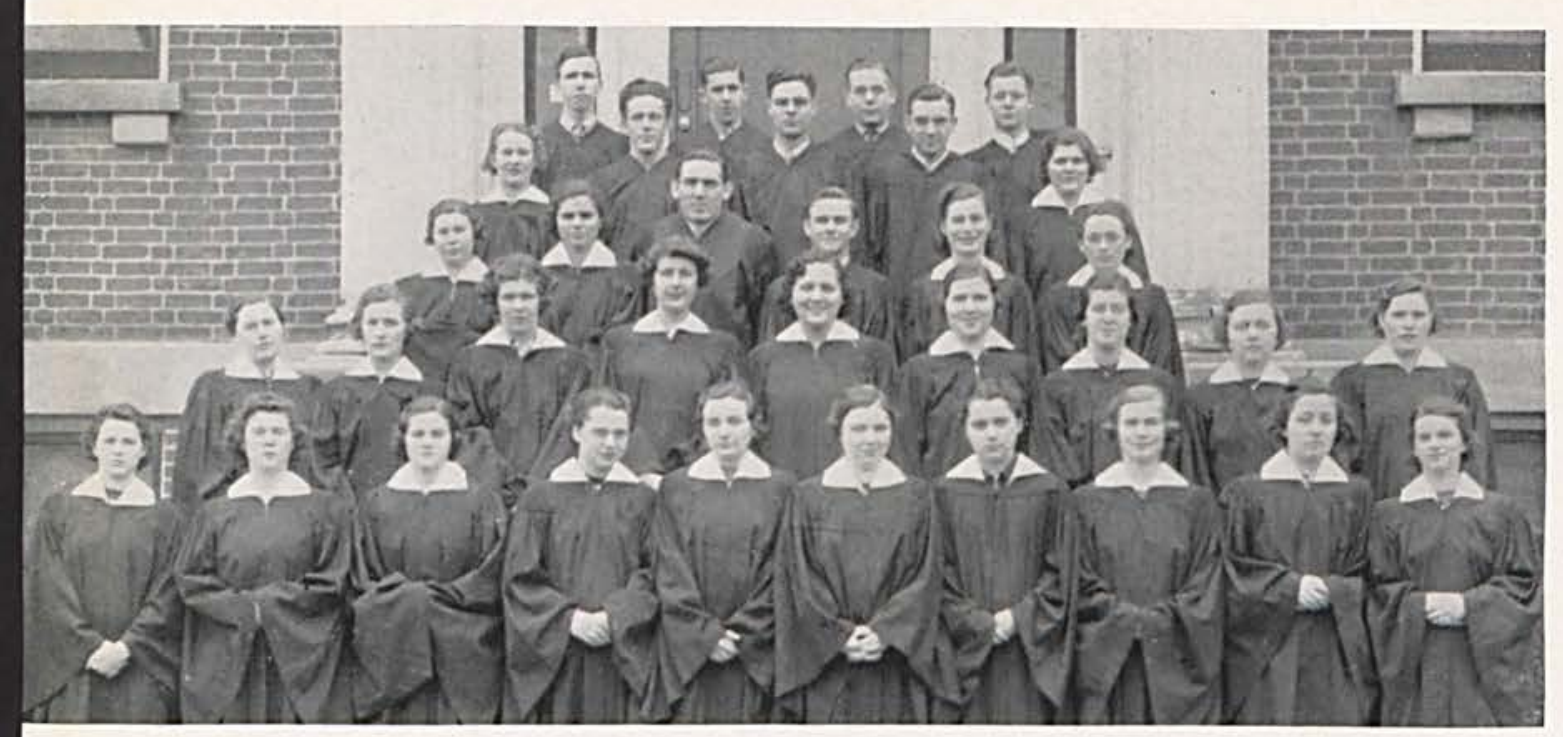

First Row: Margaret Olinger, Donna Zeller, Opal Seamon, Rosalyn Guthrie, Jean Elliott, Mrs. Creswell, Rsenni Guthrie, Rachel Creswell, Rachel Harriman, Elinor Young.

Second Row: Beatrice McClellan, Virginia Townsley, Mary Jean Townsley, Beatrice Gray, Dorothy Kennon, Martha Bryant, Irene Goodin, Helen Mossbarger, Anna King.

Third Row: RichardMacknight, Grace Bickett, Elizabeth Anderson, John. Taylor, Ray Sission, Junia Creswell, Jean Stoddard.

Fourth Row: Kathryn Overholser, Richard Macknight, James Anderson, Justin Northup, Edna Anderson.

Fifth Row: Ted James, Neil Hartman, William Lott, Fred Lott.

\section{THE \\ MIXED \\ CHORUS}

○

THE 1938 CEDRUS

The largest singing organization on the campus is the College Mixed Chorus, composed of thirty-six members, with their accompanists, Martha Bryant at the organ and Rachel Harriman at the piano. They gave two im. portant concerts during the year-at Christmas time, "The Holy City" by Gaul, and on Easter night, "The Crucifixion" by Stainer. At other times during the year they took trips and broadcast over WHIO, Dayton, on April lOth. They gave both religious and secular programs, singing in choir robes and maintaining a dignified appearance, as well as a high standard and caliber of singing. They presented the special music at all college convocations and at the Men's Bible Reading Contest, as well as at the special church meetings in March.

Everywhere they were hailed with warm praise and enthusiasm. 


\section{GIRLS'}

\section{GLEE}

CLUB

The sixteen members of the Girls' Glee Club worked incessantly during the year, not only in learning music and in giving concerts, but also in selling eats at the basketball games to pay for their uniforms, blue and gold sweaters worn with blue skirts. They rendered the special music at the Girls' Bible Reading Contest March 27th, and presented spring secular programs at the end of the year. Their Christmas Carol Concert and Bazaar, interrupted by icy weather, was given in chapel before the whole student body.

The skating party on April 12th, sponsored for the whole school, with the High School Seniors as guests, climaxed a series of busy activities which required the cooperation of every girl in the Glee Club.

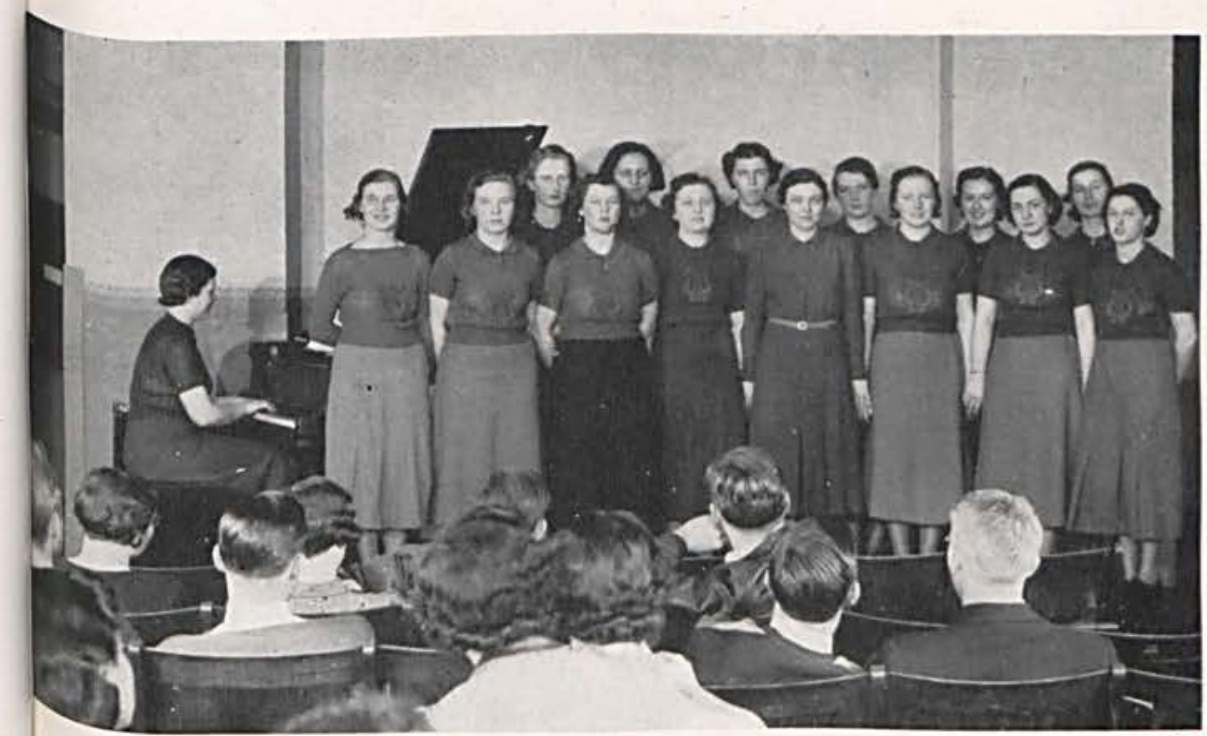

First Row: Rachel Creswell, Florence Ferguson, Donna Zeller. Helen Mossbarger, Mrs. Creswell, Marie Collins, Louise Jacobs, Margaret Olinger.

Second Row: Betty Rowe, Dorothy Kennon, Betty Shaw, Pauline Ferguson, Mary Johnston, Junia Creswell and Martha Bryant, pianist.

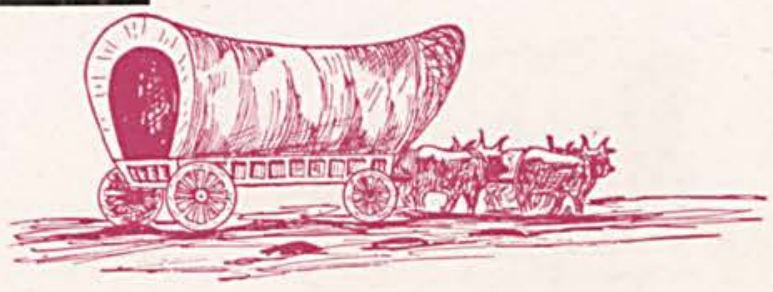

Page Forty-Five 

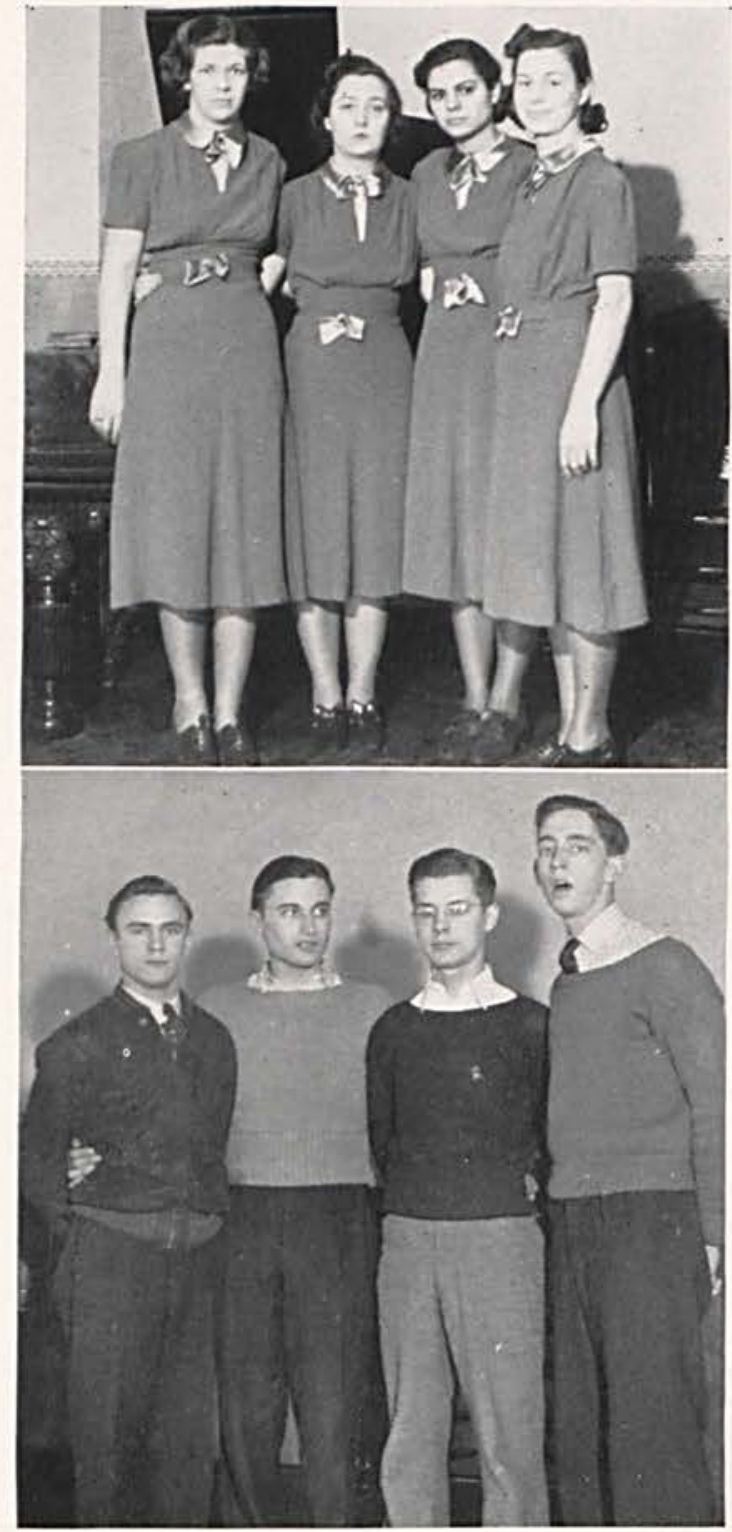

Mary Jean Townsley, Rachel Harriman Elizabeth Anderson, Junia Creswell.

Ray Sisson, Don Foulks, Fred Lott, John Peterson.

\section{COLLEGE QUARTETTES}

A new organization on the campus this year, the Melody Maids, was composed of Mary Jean Townsley, Rachel Harriman. Elisabeth Anderson, and Junia Creswell, all Freshman girls. They sang at various functions on and off the campus, and wore their costume dresses in orange and blue for their performances. Being so well received their first year, they hope to continue their melody together as long as they are in College.

The boys' quartette, the College Harmonizers, comprised of Ray Sisson, Don Foulks, Fred Lott, and John Peterson, which achieved unusual success last year, again held on to their fine reputation this year. They gave innumerable concerts, both sacred and secular, under the direction of Mildred Bickett Creswell, Director of Music.

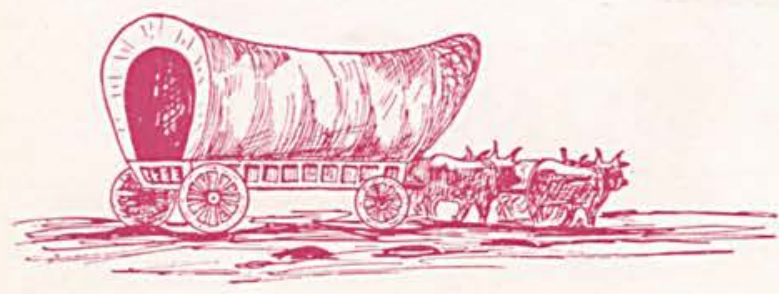

Page Forty-Six 
The musical activities of 1937-38 brought to the campus and to numerous outside engagements, programs which will long be remembered by all. More than half of the student body registered for musical courses, and the keen interest shown in every phase of its work, indicates the degree of interest with which Cedarville College students enter into a fully developed musical program.

Besides the private lessons in organ, piano and voice, and theory lessons in harmony, solfeggio, history of music, orchestration and pedagogy, a number of extra-curricular activities were maintained, such as, the Mixed Chorus of thirty-six members, the Girls' Glee Club of sixteen members, the Melody Maids (freshman girls' quartet) and the Harmonizers (boys' quartet). All of these organizations rehearsed regularly and learned a high standard of repertoire, giving progams at nearby churches, schools and club meetings.

Recitals were given at various intervals during the year, both at the local churches and in the college chapel. This broad musical activity program offered every student ample opportunity to engage in that phase which interested him most. The whole work of the department is under the direction of Mildred Bickett Creswell, Director of Music.

As a special activity in the Music Department during the second semester the organ students were organized into a class which studied the mechanical construction and registration of organ stops under Mrs. Creswell's direction. The class met once a week aside from their lessons, studying the organ and its possibilities and worked out charts of special registrations on the Presbyterian Church Organ. Recitals were given in which every member of the organ class participated. At the end of the course those who had completed all requirements were prepared to teach the organ and to play it in a superior manner.

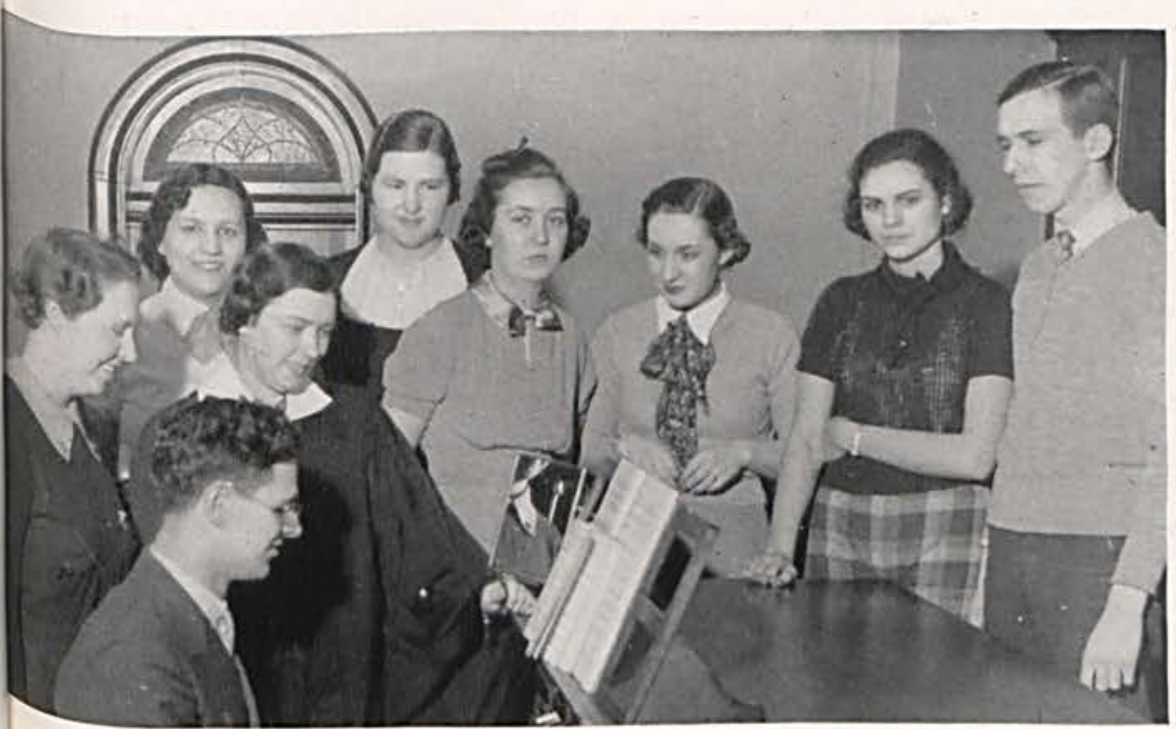

DEPARTMENT
Mary Margaret McMillan, Dorothy Kennon, Mrs. Creswell, Martha Bryant, Rachel Harriman, Louise Jacobs, Elisabeth Anderson, Ted James, and James Anderson at theorgan.

THE 1938 CEDRUS 
First Row: Anna King, Doris Ramsey, lrene Goodin, Kathryn Overholser, Mary Johnston.

Second Row: Kenneth Sanderson, Ted James, Junia Creswell, Rachel Creswell, Don Foulks, Bennett McNeal.

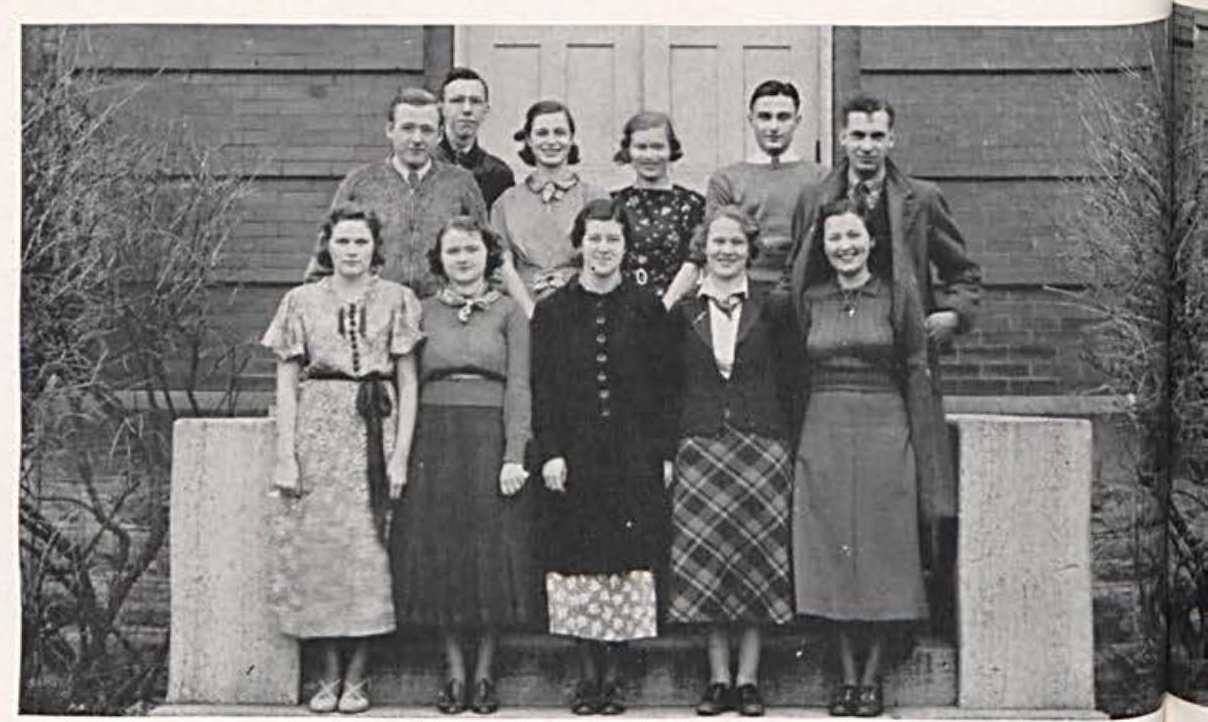

The Cedarville College Gospel Team under the direction of Donald Foulks has experienced one of the most active years in its history. The team has presented more than twelve programs in Xenia, Jamestown, Cedarville, Bowersvilie, Plattsburg, South Vienna, Catawba, and other rural churches. Every member of the team has participated in one or more of these worship services either as a speaker, musician, or devotional leader; and each one has enjoyed this experience of presenting Christianity to others. The team has not only had an enjoyable time in presenting these programs; but was royally entertained by the ladies of the Methodist Church at Lytle and in the home of the Rev. Mr. and Mrs. Ross McNeal of Plattsburg.

Membership in the Gospel Team has afforded a real opportunity for students to popularize the Christian principles of Cedarville College and to present to some churches a few of the ideals of youth.

THE 1938 CEDRUS 


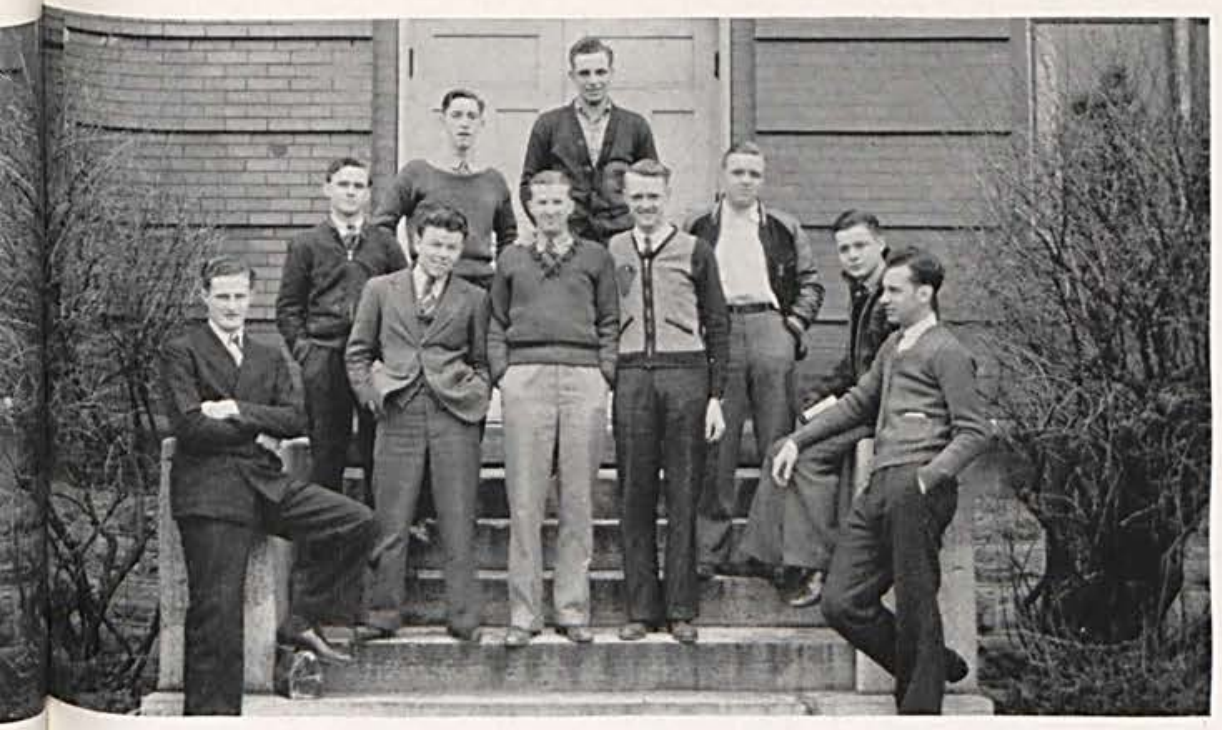

First Row: H. Swaim, J. Gillespie, H. Cummings, F. Lott, B. McNeal.

Second Row: R. Sisson, J. Peterson, K. $\mathrm{McNeal}, \mathrm{R}$. Linton.
DELTA

KAPPA

SIGMA

The Delta Kappa Sigma Fraternity has been hampered very much this year by the lack of a house. We were forced to move out of our rooms in the bank building when it changed hands. Our activities of the year consisted of an all school party, tag day, and several "pep meetings." The fraternity did much to keep the good old college spirit alive.

The officers were Roy Linton, President; Herbert Cummings, Vice-President; Bennett McNeal, Secretary-Treasurer; and Noah Sharpe, Sergeant-atArms. Later in the year John Peterson assumed the duties of the president. Fred Lott and Noah Sharpe were also elected as new officers.

Although the fraternity has not been so active this year as we would have liked, we feel the year has been successful and worthwhile because of the everlasting friendships which we have formed.

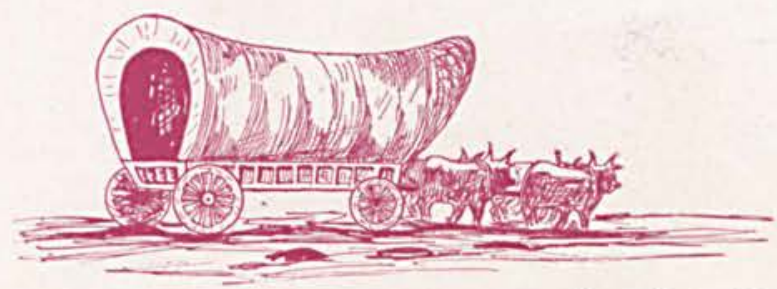

Page Fort $y$-Nine 
R. Stebbins, J. Frame, G. Bickett, B. Shively, H. Crawford, L. Walton, M. Bingamon, C. Harbaugh, F. Pidgeon.

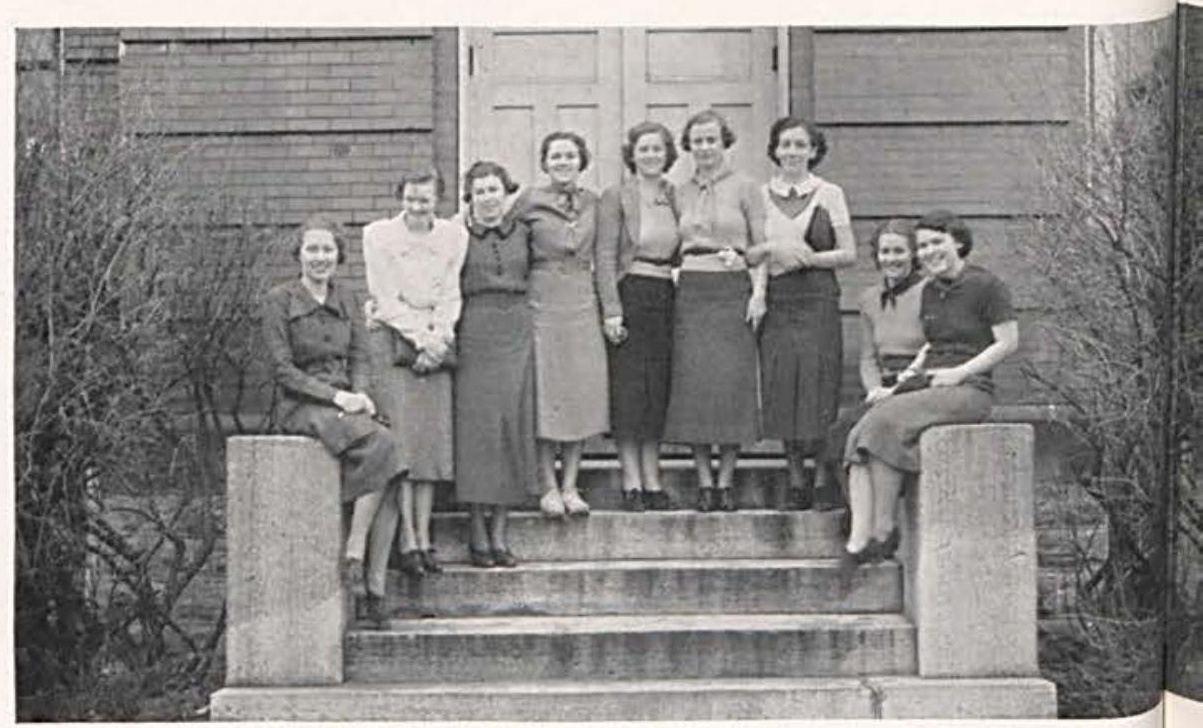

During the first semester this year, four new members were pledged to Alpha Theta Tau Sorority. Since some of them were practice-teaching, they did not ride the goat until their work was finished. At the ride, which was held at the home of Mrs. Kling, they received the "good wishes" of the other members. Dorothy Bennett was declared the windiest girl in the crowd, and she kept two girls busy for five minutes brushing off the flour. The pledges were required to furnish the refreshments, but the big mistake made by the rest of us was in promising to eat whatever was prepared for us. A menu of raw-oyster salad, salty milk, and graham crackers filled with a mixture of caramel and inner tube is not exactly our idea of an excellent meal, but we did our best.

On February 17, a second group of girls ran the gauntlet for dear old Alpha Theta Tau. Amid the odors of special A O T perfume and burning hair, the girls did not appear to be very brave, but they stayed with it and came out victorious over the goat. Crazy hats, raw oysters, paddles, a walk through town, and pictures of the boy friends of the pledges were among the highlights of the evening. (Some of the fellows around here would not appreciate it if they could see the pictures presented with their names.) Formal initiation took place on May 17, and now the girls are real members of Alpha Theta Tau.

Besides our initiations, we have had many other interesting meetings and parties-especially those when some of the group insisted on playing truth and consequences.

To the members who will leave us at commencement time, we wish much success as they start to teach. We are hoping to see our new members back next year ready to take up the job of keeping life in our sorority.

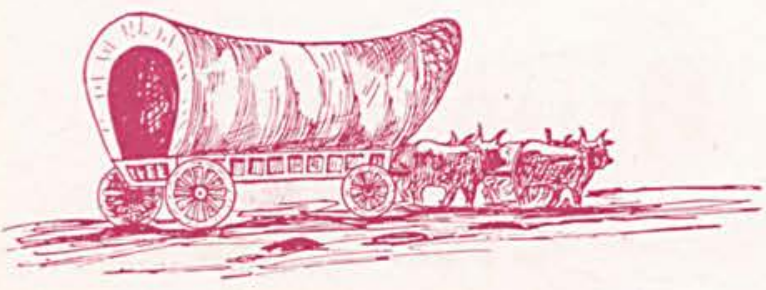

Page Fifty 


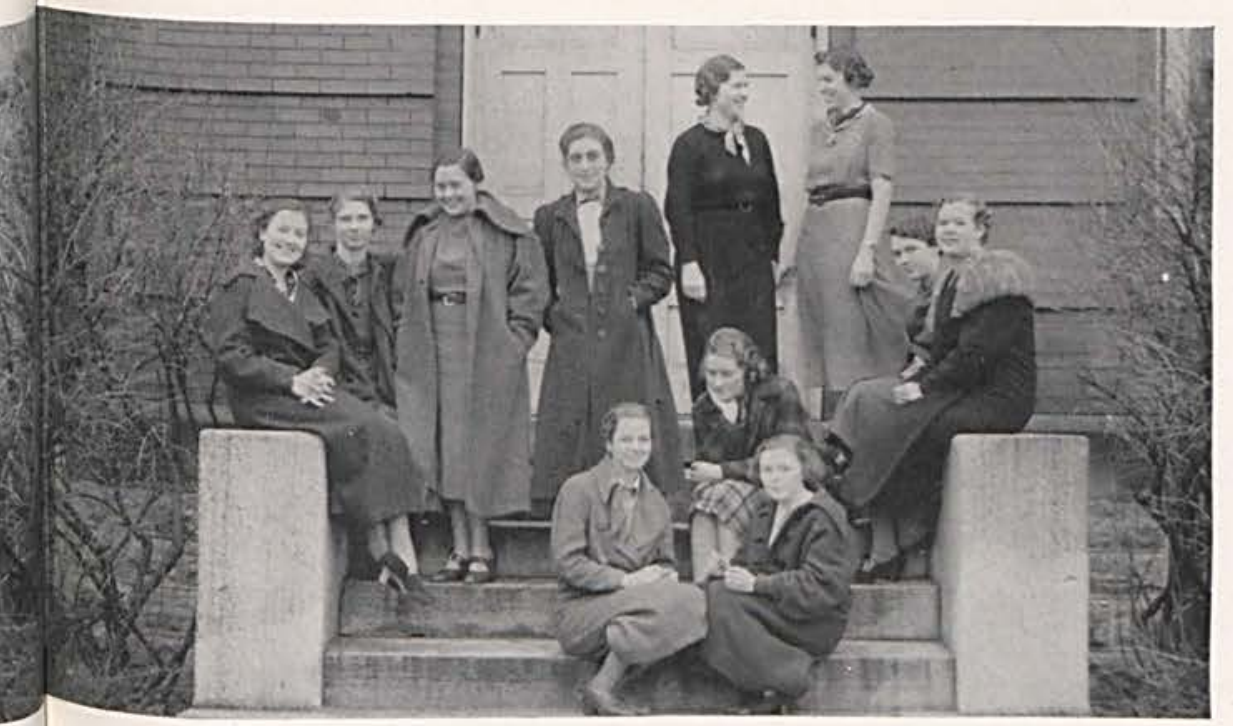

Under the supervision of Miss Basore and the leadership of Presidents Frances Kimble and Genevieve Jesson, the sorority has flourished this year.

There were only three active members left when classes started in the fall. The first thing that was done was to initiate the pledges left from last year.

Extensive plans for the year were made early in the first semester at a dinner party given by Frances Kimble. During the Christmas vacation we welcomed our alumni and initiated two pledges at a luncheon at the College Club.

Pauline Ferguson entertained the sorority at a dinner to open the new semester. Seven Freshmen were pledged and for the first time pledge pins, in the form of silver keys, were presented.

This last semester, instead of using one of the college rooms for our meetings, we secured the use of a room at Mrs. Morton's. We have offered something new in the line of stationery to the students of the college. We have secured stationery with the college seal on it.

With the help of Jessica Taylor, we have selected two sorority songs. We feel that the programs at our-meetings, including book reviews, etiquette lessons, and the display of musical talent, have proved very profitable as well as interesting.

The fun we've had together at pot-luck suppers, theater parties and such, have helped form lasting friendships which mean so much. The pledges were given a good work-out at the all-college party we sponsored this spring.

We are ending our school year with a party for the alumni. We look forward to a good time at our summer camping week at Indian Lake. So with hopes that our sorority will in the following years come to mean more and more to its members and will make itself felt on the campus, we close a year filled with happy memories.
Center: G. Jesson, G. Clemans, M. Bartley, M. Johnston, Miss Basore, B. McClellan, W. Kelso, M. Bryant, B. Shaw, P. Ferguson, R. Tavenner.

\section{$\mathrm{CHI}$}

SIGMA

$\mathrm{PHI}$ 


\section{Atbletics}

Cold, long winters $=$ almost unendurable hardshipg $=$ these developed the manhood of the forthwest in 1787.

ftlan has conquered these but still he needs a challenge, ftrodern competitive athletics furnishes that challenge to American flouth today. 


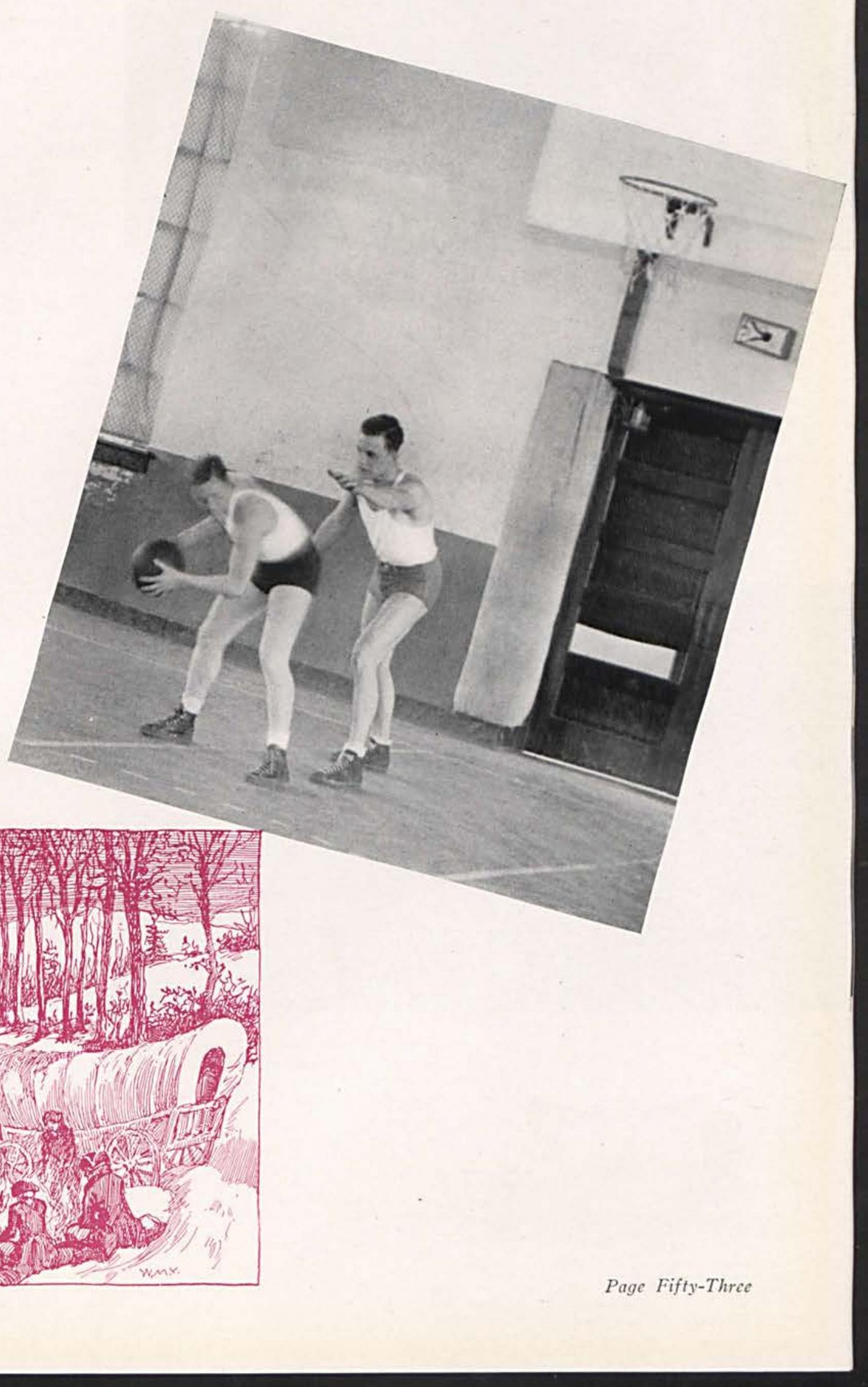




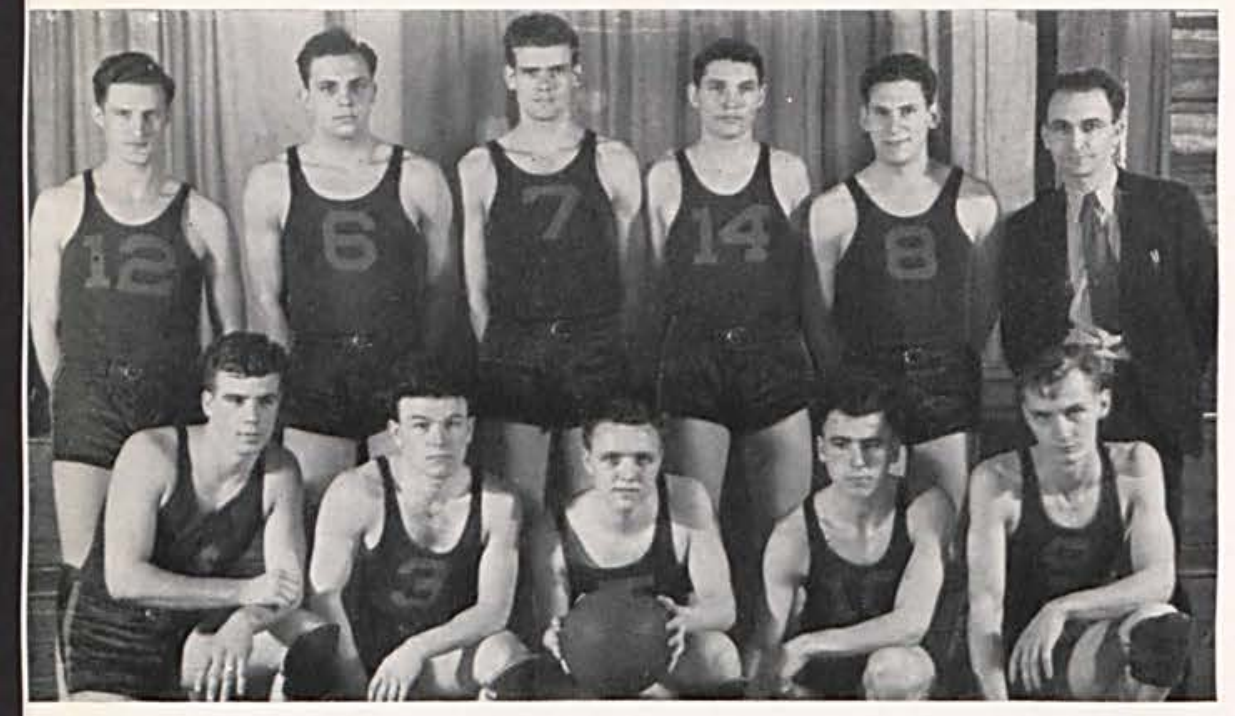

First Row: C. Walker, J. Gillespie, R. Linton, C. Wiseman, R. Reed.

Second Row: H. Swaim, K. McNeal, R. Roberts, E. Kavanagh, C. Thomas, Coach Ault.

\section{THE}

CAGE

SEASON

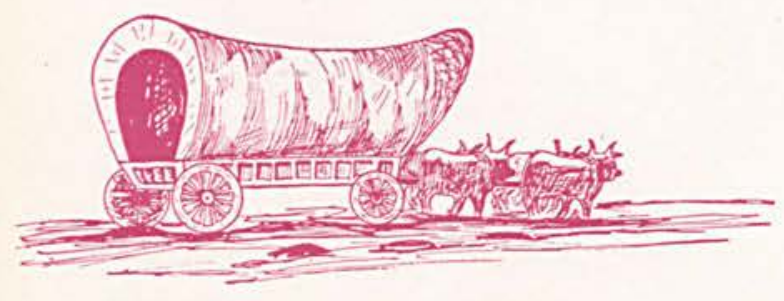

Date Opponent Ced.-Opp. Place

December 4.... Y.M.C.A. Spfg.. . . 43-25 .......... Cedarville

December $7 \ldots$ Wilberforce...... 21-22 .......Wilberforce

December 11... Otterbein.......27-28 ......... Otterbein

December 16...Wilmington...... 28-42 .......Wilmington January $15 \ldots$ Giffin ......... 48-28 ........ Van Wert

January 21 .... Bluffton....... 43-34 ......... Cedarville

January $25 \ldots$. Wilberforce...... 33-34 ......... Cedarville

January $28 \ldots$. Y.M.C.A. ...... 43-38 ....... Springfield

January $29 \ldots$... Giffin..........40-31 ......... Cedarville

February 5.... Rio Grande. ..... 30-27 .......... Cedarville

February. 11... Defiance....... . 32-25 ........ Cedarville

February $14 \ldots$ Bluffton....... 34-30 .......... Bluffton

February 17 ... Rio Grande...... 27-29 ....... Rio Grande

February $22 \ldots$ Wilmington...... 32-26 ......... Cedarville

Page Fifty-Four 

Ist row: Clyde Walker, La Verne Whipp. Ceci! Thomas, Raymond Sisson, Eldon Gillespie, 2nd row: Robert Reed Justin Northup, James Jackson, Harold Thomas, Donald Foulks, Coach Ault, Melvin Thompson, John Gillespie.

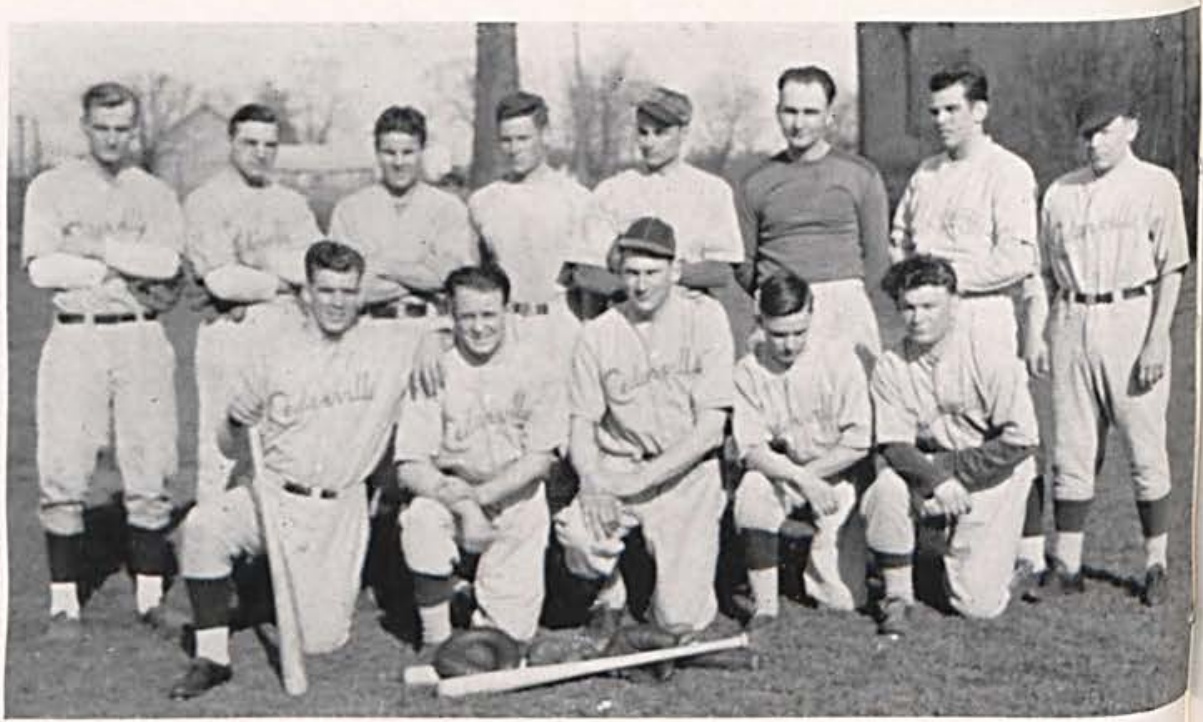

April 29

May 7

May 10

May 13

May 19

May 23

May 27

June 1
Wilberforce Here

Miami There

Wilmington There

Bluffton There

Wilberforce There

Ohio State Here

Bluffton Here

Wilmington Here 
The baseball team is looking forward to another successful season on the diamond. The Yellow Jackets finished second in the Northwest Conference last year. Several regulars are back this year; so we are looking for the Cedarville College baseball team to be near the top of the conference again.

The team should be strengthened somewhat by some freshmen boys who appear to have what it takes to be a baseball player.

The regulars who are back from last year are James Jackson, catcher; Melvin Thompson, pitcher; Clyde Walker, first baseman; Raymond Sisson, second baseman; John Gillespie, fielder; Elden Gillespie, third baseman; and Cecil Thomas, fielder.

Miami University of Oxford will appear on the schedule again after several years' absence from C. C. athletic calendar, and the boys hope to raise their prestige by defeating the "Redskins."
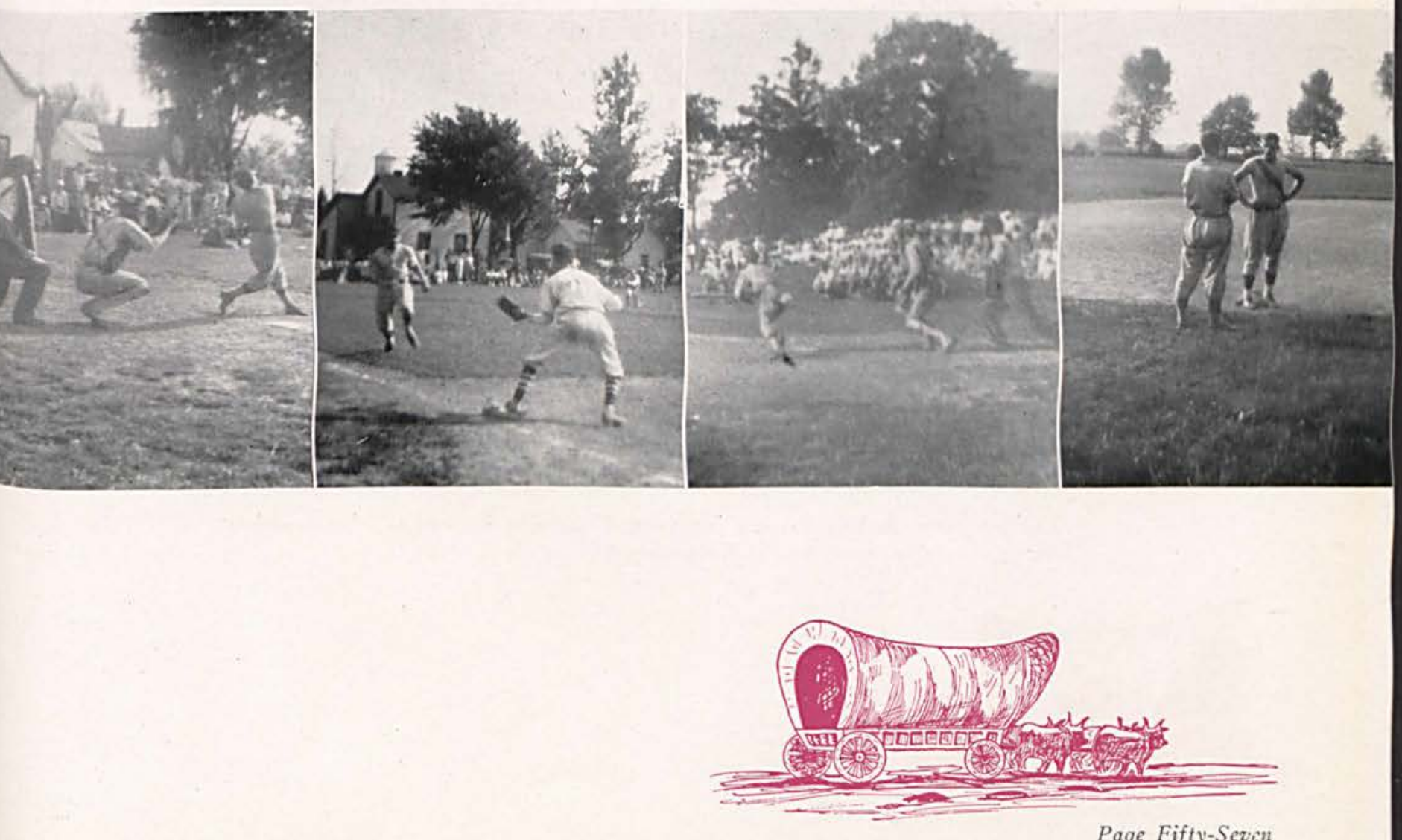


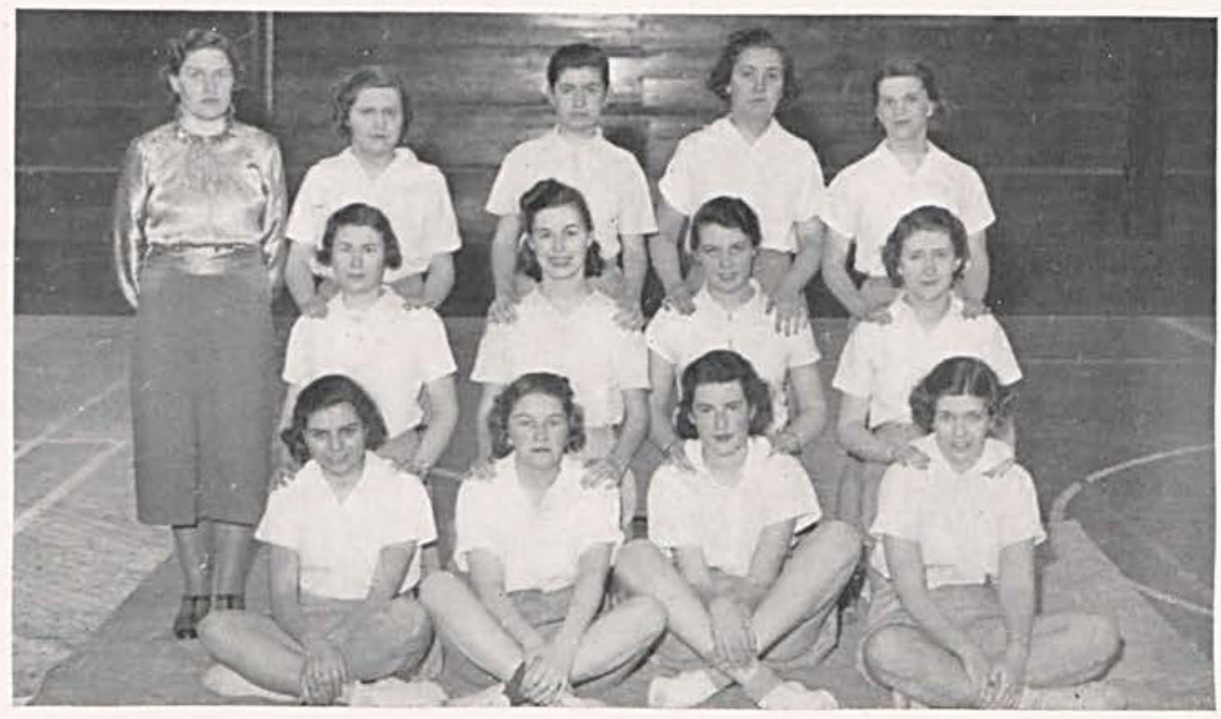

First Row: E. Anderson, G. Clemans, O. Marshall, M. J. Townsley.

Second Row: G. Bickett, J. Creswell, P. Ferguson, E. Edgington.

Third Row: A. King, H. Chitty, V. Henderson, R. Harriman, E. Young.

\section{WOMEN'S PHYSICAL EDUCATION}

The Women's Physical Education class of Cedarville College has had a very successful year under the supervision of Miss King.

After some very beneficial training they were taken to Cincinnati to participate in the play day exercises. The sports in which they were entered were basketball and volley ball.

The girls came home with two victories. They played the University of Cincinnati in volley ball and won by a score of 22-21. They played the University of Kentucky in basketball and won by a score of 39-14. Orena Marshall, an outstanding member, was the high point player. Edgington and Henderson, our fast running forwards, aided Orena in making the high score.

Anderson and Townsley played a strong defensive game. Harrison and Clemans showed their ability in playing the position of guard.

Our volley ball team consisted of our basketball team with the assistance of Grace Bickett and the coach. Anna King.

We are very pleased with the success of our team; as it ranked very high in the sports in which it participated at Cincinnati.

We hope that in the coming years Cedarville College will have such a fine group as they have had in the past year.

\footnotetext{
Page Fifty-Eight
} 


\section{MEN'S PHYSICAL EDUCATION}

Here is a brief account of what happened in the Boys' gym class this year.

In the beginning of the year we played soft ball and some hard ball out on the campus. As the weather grew colder, we turned to that superdynamic sport called soccer, with a few football scrimmages mixed in.

The month of November found us in the sym doing exercises; such as jumping, running, swinging on the parallel bars, and doing many other gymnastics. After about three weeks of these exercises we took up volley ball. This proved to be fun for all of us.

But soon volley ball gave way to King Basketball; and, while he reigned, we had fun and exercise both mental and physical, mixed well and served hot. We gave the varsity and the second teams something on which to work outand we made them work!

King Basketball abdicated in favor of good King Baseball. Many of the boys took up this game seriously, while others just stayed with soft ball. This we did all spring.

It is our business to make strong bodies as well as strong minds, and we think each one of the boys will agree that he is harder now than he was when he started this course.

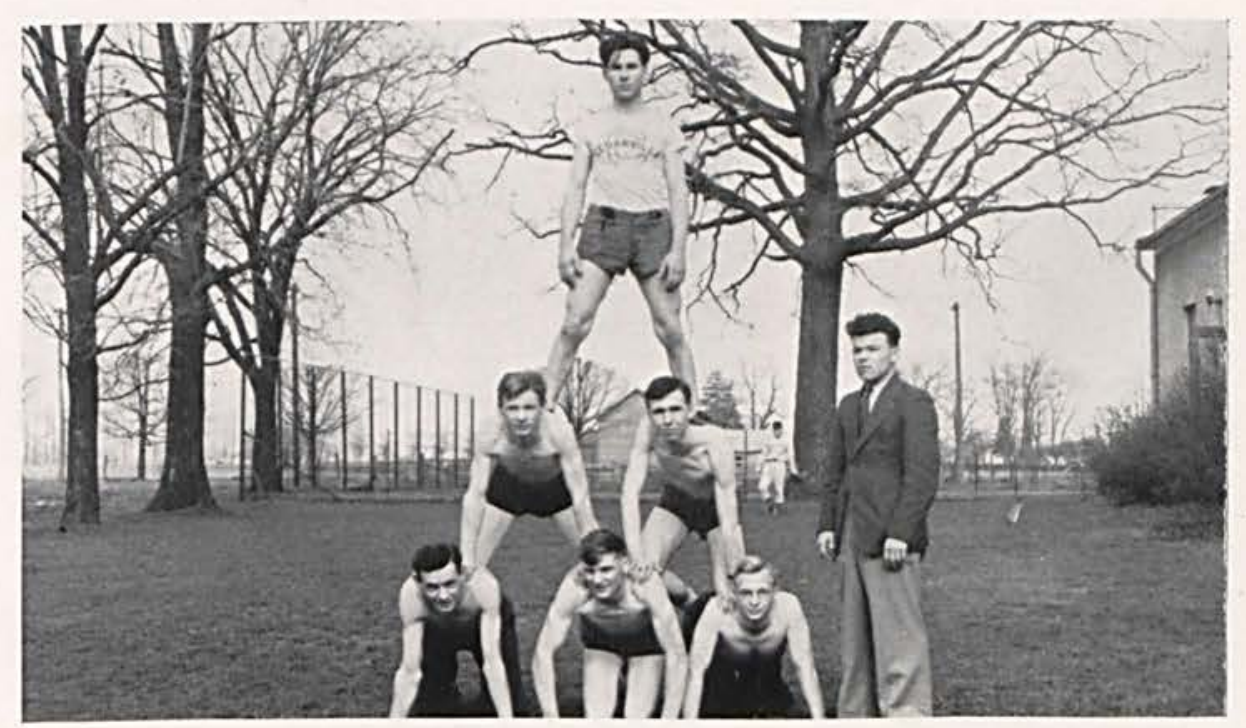

Ist row: Monroe Pyles, Elwood Shaw, Arthur Geake. 2nd row: Roydon Johnson, Ted James. 3rd row: Orvile Labig. John Gillespie, standing. 

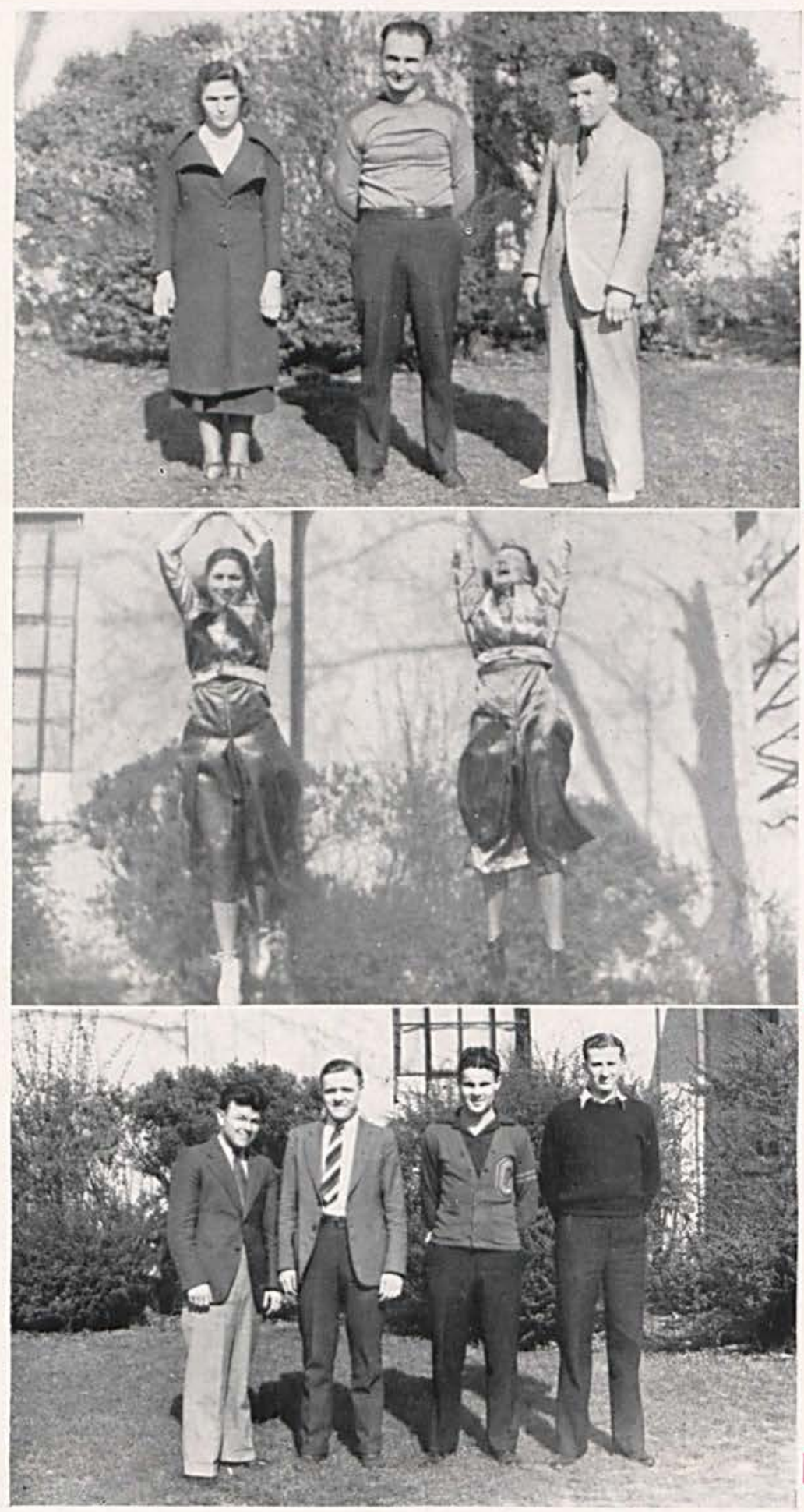

THE 1938 CEDRUS 
Coach Ault and his two assistants have ably handled the physical education program of Cedarville for the past year. Miss Anna King has directed the Girls' Physical Education and has especially emphasized the active sports. John Gillespie has been in charge of the boys' physical education class.

\section{Cedarville — Rah! Cedarville - Rah!}

Rah! Rah! Cedarville!

Jane Frame and Merieum Foulk were Cedarville's lively cheerleaders for the 1937-38 basketball season. They were a large factor in the success of our team with their peppy yells and enthusiastic leadership. The new bright uniforms of orange and blue added to their effectiveness.

During the 1937-38 season Cedarville College was well represented with basketball officials who journeyed to High Schools in Greene and other surrounding counties to officiate several basketball games.

Those that took part in these games were Roy Linton, Herbert Cummings, John Gillespie and James Jackson, who were members of the O.H.S.A.A.

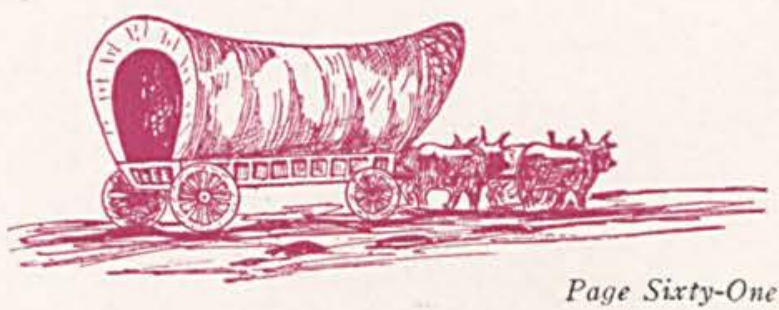




\section{Features}

Life has always been more than sleeping, eating, and working. Parties, songs, celebrations gavly punctuated the otherwise dull life of the piomerg.

Che traditional Cedar Day pageant, breatb-taking games, and moving oramas = all these help to make Cedarville College. 

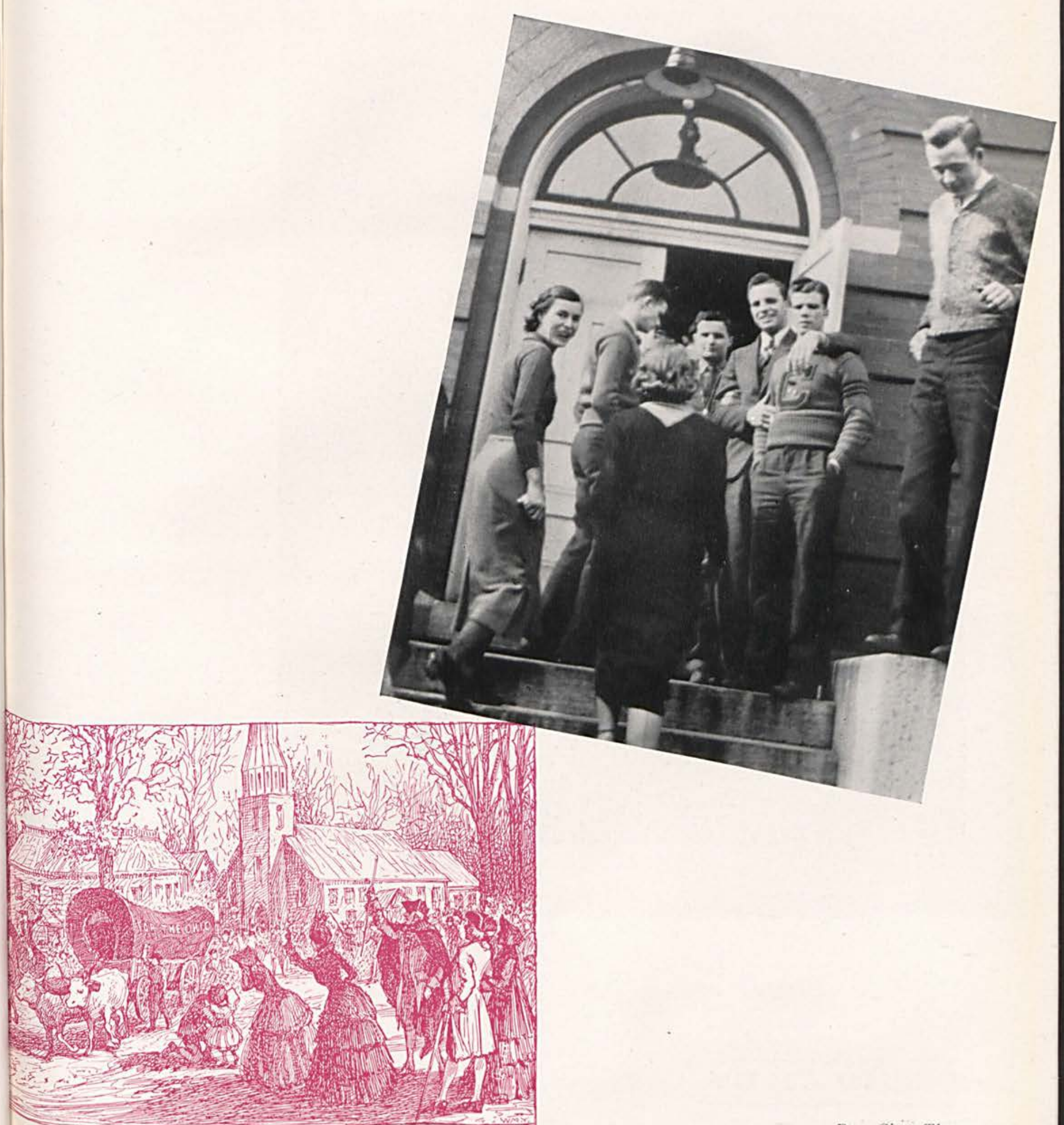


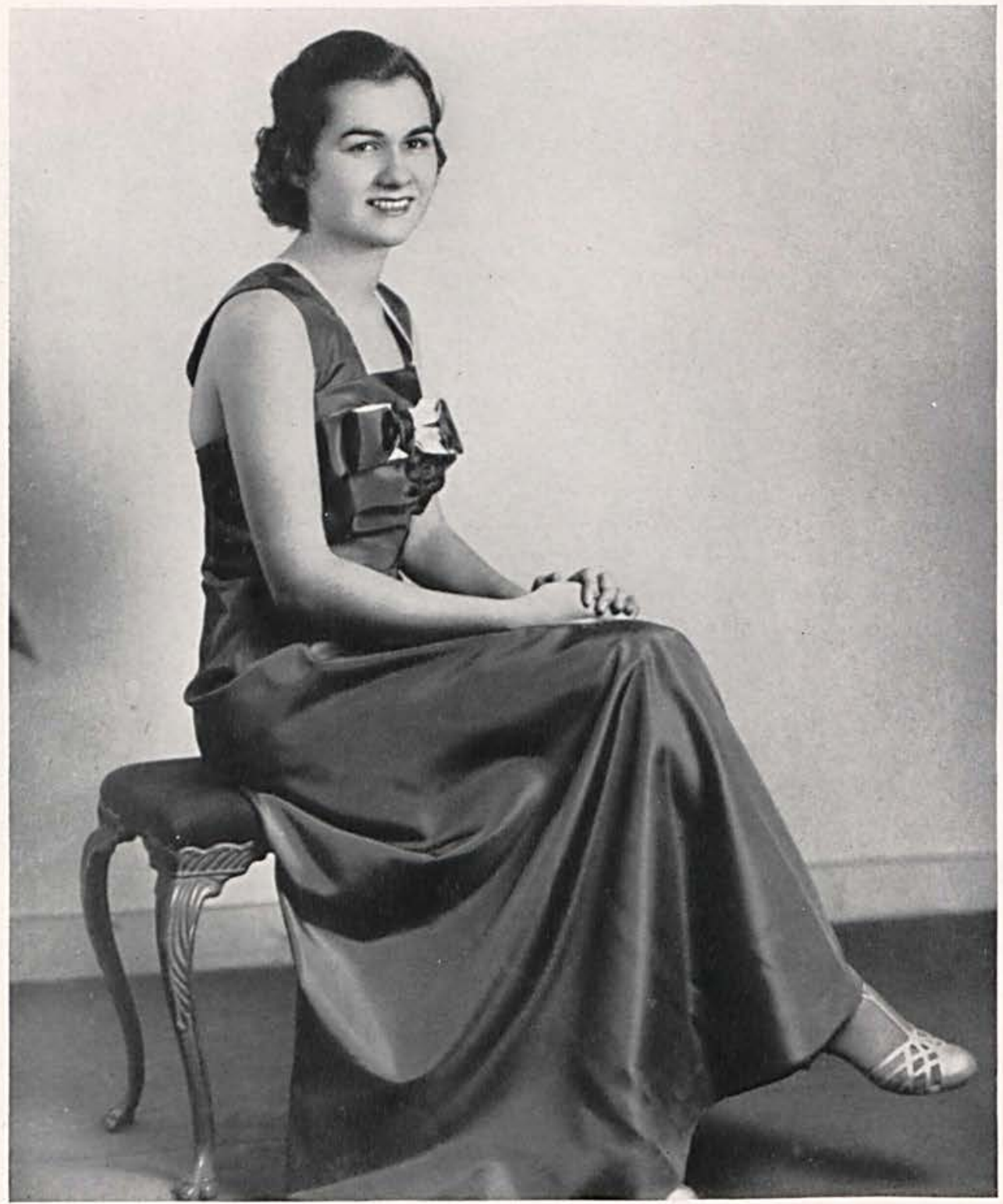

MISS DOROTHY ANDERSON

Cedarville, Ohio

THE 1938 CEDRUS

Page Sixty-Four 


\section{Cedar}

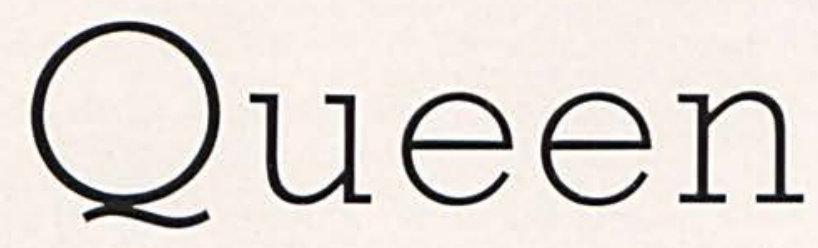

1937
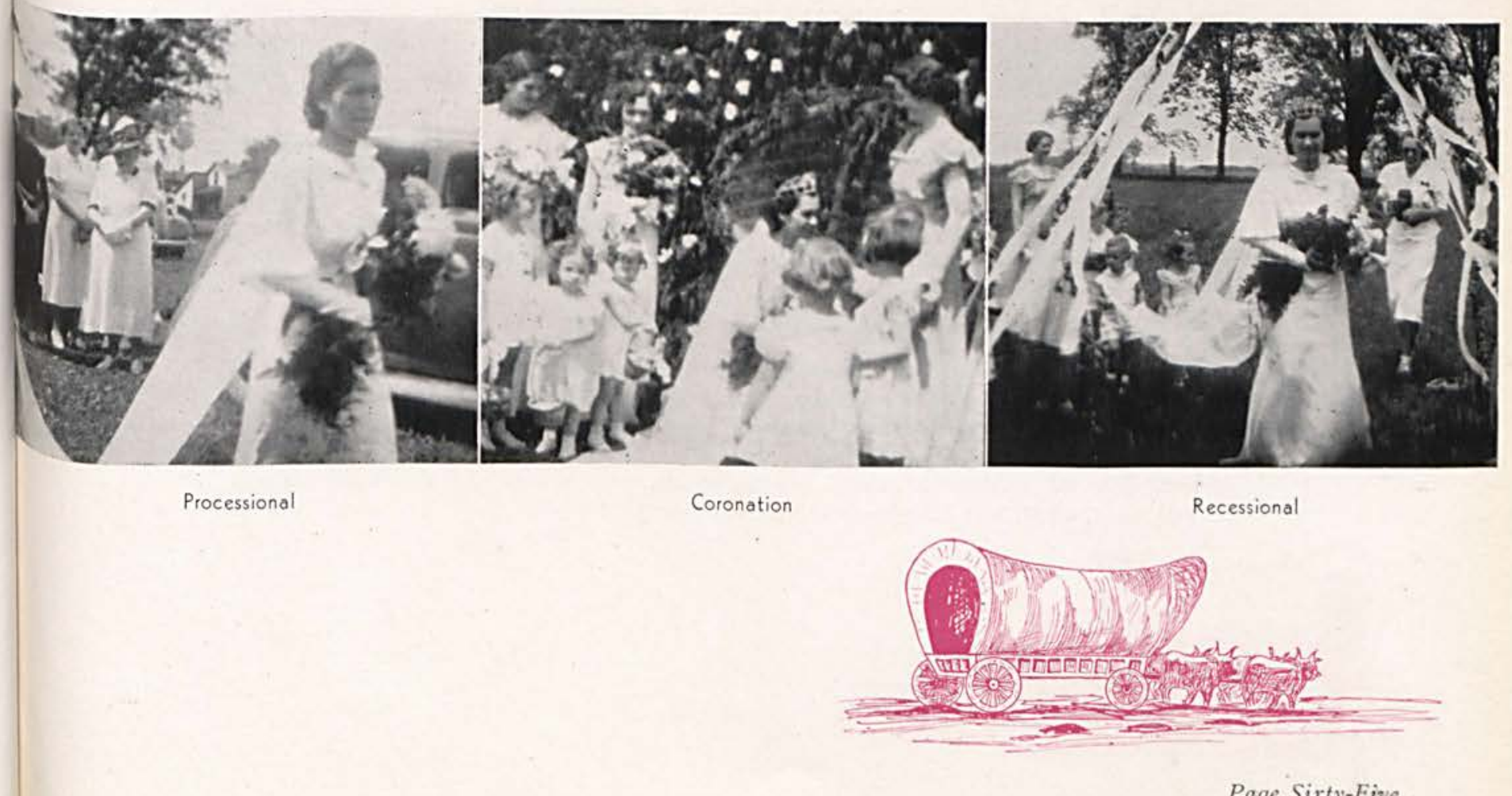

Page Sixty-Five 


\section{Y. W. COMMITTAL SERVICE}

The members of the Y. W. C. A. reconsecrated themselves in a lovely candlelight service at the Presbyterian Church, November 18th. The freshmen girls took the vow for the first time.

The service was introduced by a fifteen-minute organ recital by Martha Bryant and impressive music furnished by the girls' quartet.

The girls, old members and new, lighted their candles from those of the cabinet and followed the president in a lovely recessional.

\section{CLASS TOURNAMENT}

The first game of the class tournament between the Sophomores and the Seniors was the highlight of the tournament. It seemed certain victory for the Sophs, who were leading one point with only ten seconds to go, when Kenny Sanderson looped in a one hand shot from the corner of the floor.

In the second game of the tournament the Freshmen won easily by a score of 36 to 24 . The finals proved to be a battle from the start; however, the Seniors succeeded in nosing out the Freshmen 36 to 31 . This was the second straight year these boys won the class tournament. A beautiful blue and gold cup was presented to the Senior team.

\section{METHODIST PARTY}

On September 28th, 1937, the Epworth League of the Methodist Church entertained the student body and faculty at the college gymnasium. The group entered wholeheartedly into a snake dance, the couples winding in and out among the secluded spots of Cedarville. Entertainment in the form of musical games was conducted by members of the Young People's Department of the Methodist Church, and the party was concluded with delicious refreshments served by the mothers of these young people.

\section{HALLOWE'EN PARTY}

Spooks and witches reigned at the college gymnasium on October 28th during the annual Hallowe'en Festival. The guests entered the back door and wound their way through a long, dark passageway filled with air blasts, electric shocks, dead rats, and ghosts. Appropriate decorations of fodder, pumpkins, and autumn leaves filled the gymnasium.

Everyone was requested to be masked as a "hayseed," and the group presented a strange assortment of country parsons, constables, scarecrows, and just plain "hicks." After a lively entertainment consisting of rustic contests, the Virginia Reel, and other games, delightful refreshments of apples, doughnuts, and cider were served.

\section{PRESBYTERIAN PARTY}

An "Indoor Track Meet" was held Thursday evening. September 9th, in the parlors of the First Presbyterian Church. On this occasion the faculty and students of the college were guests of the Christian Endeavorers. As they arrived, the students were divided into four groups representing Cedarville and three of its keenest rivals in collegiate circles. Strangely enough, running off the events of the meet revealed just who may be called "sober-sides," "best needle threaders," and "string-chewers." Cedarville, of course, was victorious. Refreshments were served in the dining room. The evening was closed with a song and a welcome to the students by Rev. Adams and one of the Endeavorers.

\section{Y. M. AND Y. W. MIXER}

On the evening of September 21, the college was entertained at the gym by the $Y . W$, and $Y$. M. The guests were greeted by a committee who gave instructions to hunt names of those who were unknown. The names were used later for a game of bingo. Games of other types were enjoyed during the evening, including the Grand March and other musical games. The evening was climaxed by refreshments of pumpkin pie, cider, and doughnuts served in an elegant manner.

Page Sixty-Six 


\section{"THE LATE CHRISTOPHER BEAN"}

The Dramatic Club presented Sidney Howard's comedy, "The Late Christopher Bean" on December 9, in the Cedarville Opera House.

Miss Genevieve Jesson portrayed in a delightful manner the role of Abby-the Haggett's servant. The story concerns a group of pictures which the late Christopher Bean had painted and which no one had taken seriously with the exception of Abby. In the final act it is revealed that Abby is Mrs. Christopher Bean and the rightful owner of the now-valuable pictures.

The other members of the cast did a fine piece of acting with their roles as follows: Dr. Haggett, Justin Hartman: Mrs. Haggett, Jane Frame; Susan Haggett, Mary Johnston: Ada Haggett, Mary Jean Townsley; Warren Creamer, John Peterson: Gallant, Fred Lott; Rosen, John Gillespie; Davenport, James Anderson.

The play was under the able direction of Miss Glenna Basore.

\section{Y. M. C. A. MINSTREL}

The Y. M. C. A. presented its bi-annual minstrel, Thursday evening. April 21, in the Cedarville Opera House. The stage setting was the inside of a barn-baled straw, pitchforks, and a pony added realistic touches.

Mr. John Fox, as interlocutor, and the end men kept the audience in an uproar throughout the evening. Special skits were presented by Harry Sinks, John Taylor, Harold Shaw, Cecil Thomas and Justin Hartman.

The chorus accompanied by Wilmott Fischer sang both traditional and popular numbers. A hill-billy band and several solos completed the program.

\section{CEDAR DAY}

The annual Cedar Day festival was held on the morning of June 2 on the College Campus.

Miss Dorothy Anderson, the May Queen, and her attendants came in to "Pomp and Circumstance" and began the festivities. The queen was crowned by last year's May Queen, Anna Jane Wham.

The pageant itself was a dramatization of the old Greek myth of Demeter and Proserpina which related how our seasons originated. The story told of how Proserpina was seized by Pluto and taken to the underworld. This part was done magnificently by Gale Ross who rode in a realistic Greek chariot drawn by two black horses gaily adorned in flowers and wreaths.

Mr. John Richards, the Cedar Day orator, spoke on the physical qualities of the Greeks and our need for a program of physical education in America today. The pageant was planned and presented by the Dramatic Club under the leadership of Miss Santmyer.

\section{CONVOCATION SERVICE}

The forty-third annual Convocation service was held in the First Presbyterian Church on Sunday evening, September 19.

Dr. Ross Miller, pastor of the Covenant Presbyterian Church of Springfield, delivered a heart-searching message. The music for the occasion was under the supervision of Miss Bickett.

\section{BOOSTER BANQUET}

The second annual booster banquet for Cedarville College was held October 15 , in the Alfred Memorial Gymnasium. The featured speaker was the Honorable Myers Y. Cooper, former governor of Ohio. He spoke on some of the problems which face us as a nation today. Dewitt S. Morgan, superintendent of Indianapolis schools, also made a short address. A large number of alumni, students, and friends of Cedarville College attended. 


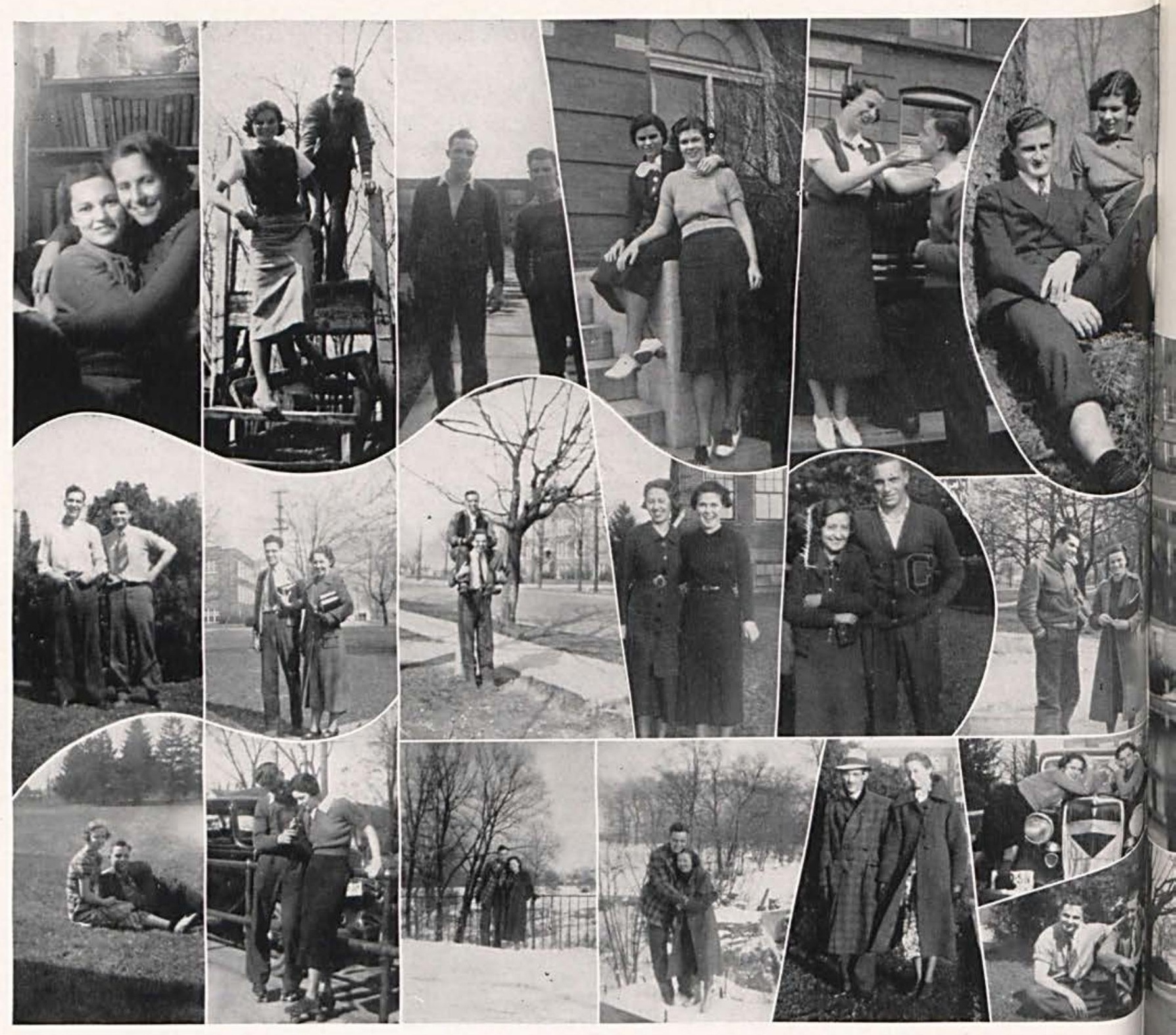

\section{WHOM YOU ARE WITH}

THE 1938 CEDRUS 


\section{WHERE YOU ARE}
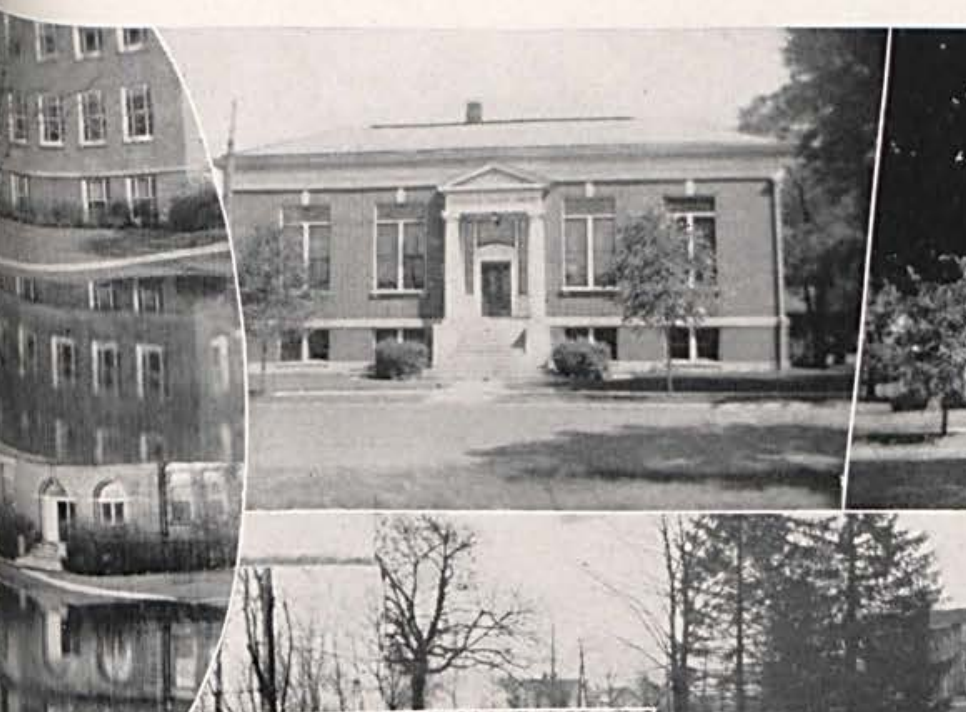

- d Whit $=5$
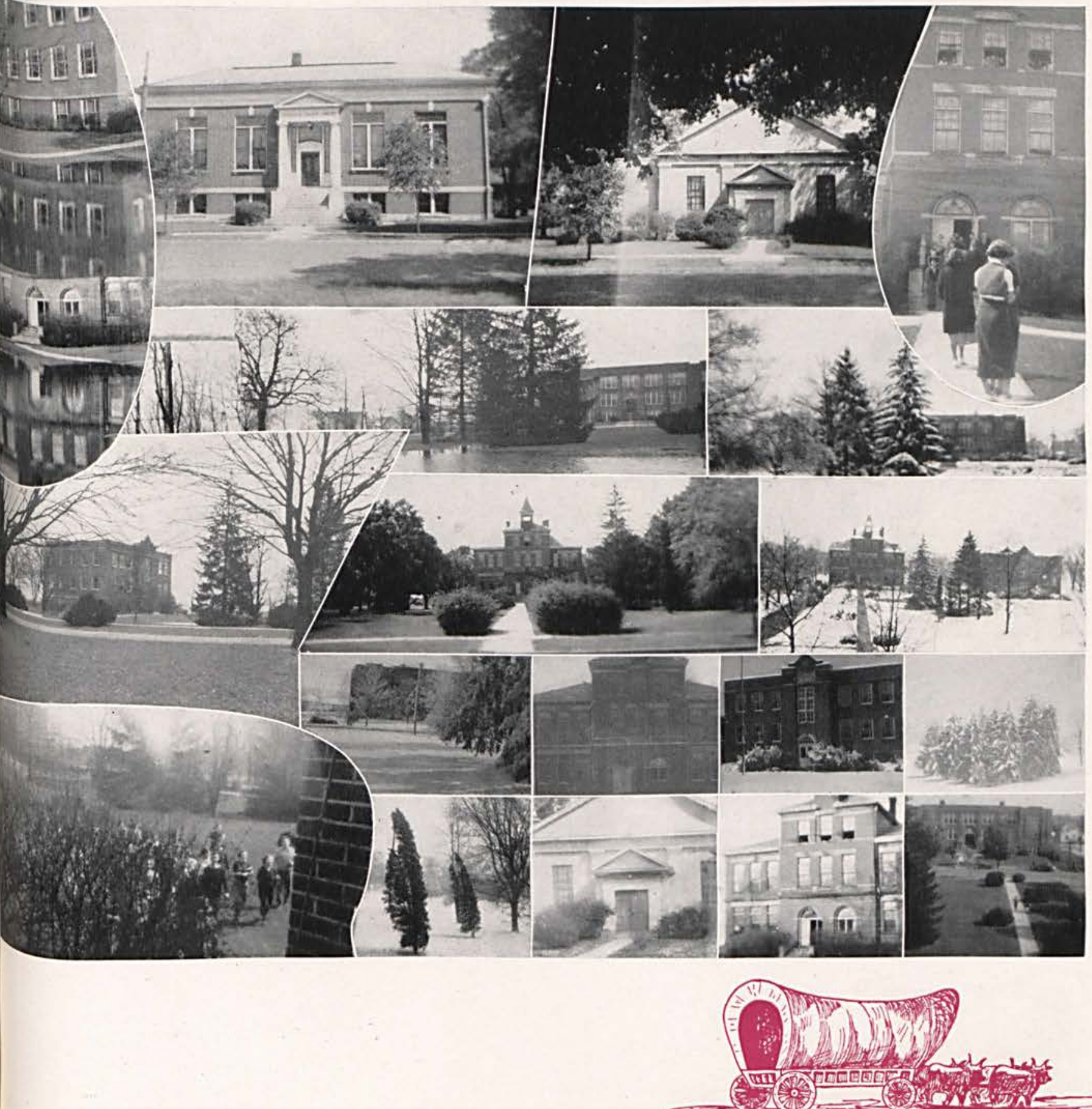


\section{MEN'S BIBLE READING CONTEST}

The Men's Bible Reading Contest, which for years has been sponsored by Dr. C. M. Ritchie, Cedarville, was held in the First Presbyterian Church, Sunday, November 7.

John Gillespie won first prize; Justin Hartman, second; John Fox, third; Raymond Sisson, fourth; and Ted James, fifth.

The College Mixed Chorus, under the direction of Mrs. Mildred Bickett Creswell, furnished special music for the program.

\section{HOMECOMING}

The largest Homecoming in the history of Cedarville College was held in the Alford Memorial Gymnasium, Saturday, February 5th. Three hundred and six college alumni, students, and friends attended this annual affair which is presented to promote and maintain a deeper friendship between alumni and students of their Alma Mater.

After a bountiful dinner served by the Ladies' Advisory Board of Cedarville College, the Yellow Jackets met the Rio Grande Quintet in a thrilling contest which was anybody's ball game to the very end. The score at the ha!f time was $15-13$, Cedarville. At the beginning of the second half the Yellow Jackets came through with eight points while holding the Rio Grande boys scoreless. With the score at $23-13$ Rio Grande rallied and tied the score at 23 all. Cedarville then gained a small lead which it held throughout the remainder of the game. The final count was Cedarville 30 - Rio Grande 27.

\section{WOMEN'S BIBLE READING CONTEST}

Sunday, March 27, fourteen young women participated in the annual Bible Reading Contest of Cedarville College. Music was furnished by the College Glee Club and the College Harmonizers.

The prizes were awarded as follows: Rachel Creswell, first; Rachel Harriman, second; Mary Johnston, third; Grace Bickett, fourth; Beatrice Gray, Rosalyn Guthrie, and Genevieve Jesson tied for fifth.

\section{Y. W. TEA}

The annual Y. W. Tea was held at the home of Jane Frame on September 16th, 1937. A musical program was presented which included the following numbers: piano solo, Mrs. Mildred Creswell; vocal solo, Rachel Creswell, accompanied by Junia Creswell on the violin; vocal duet, Beatrice McClellan and Jane Frame.

Mary Johnston, president of the Y. W. C. A., and Virginia Townsley, the Y. W. hostess, presided at the tea table. After the refreshments, the girls spent a pleasant time in renewing old friendships and making new acquaintances among the freshman girls.

\section{MOCK WEDDING}

The Y. W. sponsored a Mad Hatter's party, March 21st. Some of the latest spring models will have to look to their medals, for the hats introduced at that party displayed unparalleled taste, dignity, and beauty.

Games appropriate to a Mad Hatter's party were played-two-deep, the Farmer in the Dell, etc. The latest spring styles were modeled by college students in a style show.

The party was climaxed by the entrance of the Wedding Party. Some of the bolder souls dared to kidnap the bride. They drasged her to a car and rode madly toward Clifton. The kidnapers were kind, however, for they brought the bride back in time to enjoy the refreshments.

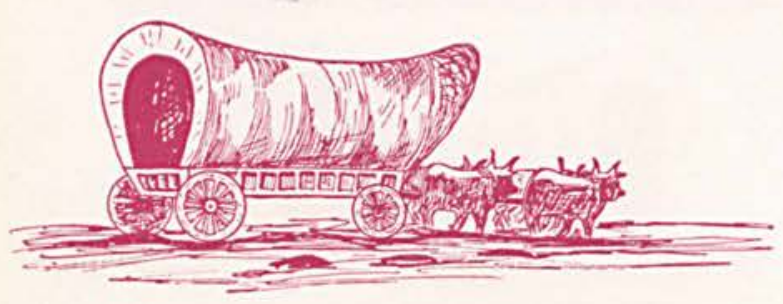

Page Seventy 


\section{DEBATE TOURNAMENT}

At $6: 30$ on the morning of Feb. 25, the debate teams left Cedarville, lugsage and all, for the Manchester-Huntington Debate Tournament. The annual stop was made at "Poppy's" filling station in Richmond where all were filled. Arriving in Huntington at 11:00, the teams were directed to the Hotel La Fontaine for lodging and to the college dining room for lunch. Debates were held Friday afternoon and Saturday morning, the Cedarville teams winning four out of twelve debates. Although the teams did not win as many debates as they might have, the debaters feel that the tournament and the season as a whole has been successful for the experience and knowledge, the contacts and friendships that all acquired.

\section{MOTHER - DAUGHTER BANQUET}

May 6, the girls of the Y.W.C.A. entertained their mothers at the annual MotherDaughter Banquet.

The welcome was given by the Y.W. President, Mary Johnston, and the response by Mrs. Fred Townsley. Music was furnished by Beatrice McClellan and Mrs. Helen Jacobs; and the girl's quartet which is composed of Elisabeth Anderson, Rachel Harriman, Mary Jean Townsley, and Junia Creswell. The speaker of the evening was Miss Mary Kyle, a missionary from India home on furlough. She spoke on the "Mothers and Daughters in India."

\section{JUNIOR - SENIOR BANQUET}

In a setting carrying out the theme of the Northwest Territory celebration, the annual Junior-Senior banquet was held at the Dayton Y.M.C.A. on May 12. The tables were beautifully decorated in green and white. At each place, concealing the nut cups and bearing the place cards, stood miniature pioneer women dressed in green and white. On the speaker's table was a replica of an old-fashioned covered wagon. White flowers formed centerpieces on the other tables. After a three course dinner there was a program of speeches and special music. After this program the group attended a moving picture in Dayton.

\section{SWIMMING PARTY}

The Y.W. and Y.M. sponsored an all-college swimming party on April 27 at the Y.W.C.A. swimming pool in Springfield. Thirty-five students attended the party which was chaperoned by Mr. and Mrs. Ault.

The ride to and from Springfield was on a truck and this in itself furnished a good part of the evening's entertainment. After a strenuous two hours in the pool the students returned to Cedarville gaily munching hamburgers as they rode.

\section{VESPER SERVICE}

A lovely vesper service was held in the Cedarville Cliffs under the leadership of the Y.M.C.A. and the Y.W.C.A. The worship service was centered around Jean Francois Millet's famous painting "The Angelus." Justin Hartman, Genevieve Jesson, Cecil Thomas, and John Fox read a story about a woman who received a copy of this painting and how it affected her life. A mixed octet sang several hymns including "Dear Lord and Father of Mankind," "Day Is Dying in the West," and "Now the Day Is Over." Bennett McNeal played "Just a Song at Twilight" on the violin as a musical background for the reading of the story. The service was ended with the singing of "Taps.'

After the Vesper Service the group enjoyed a wiener roast also held in the cliffs.

THE 1938 CEDRUS 


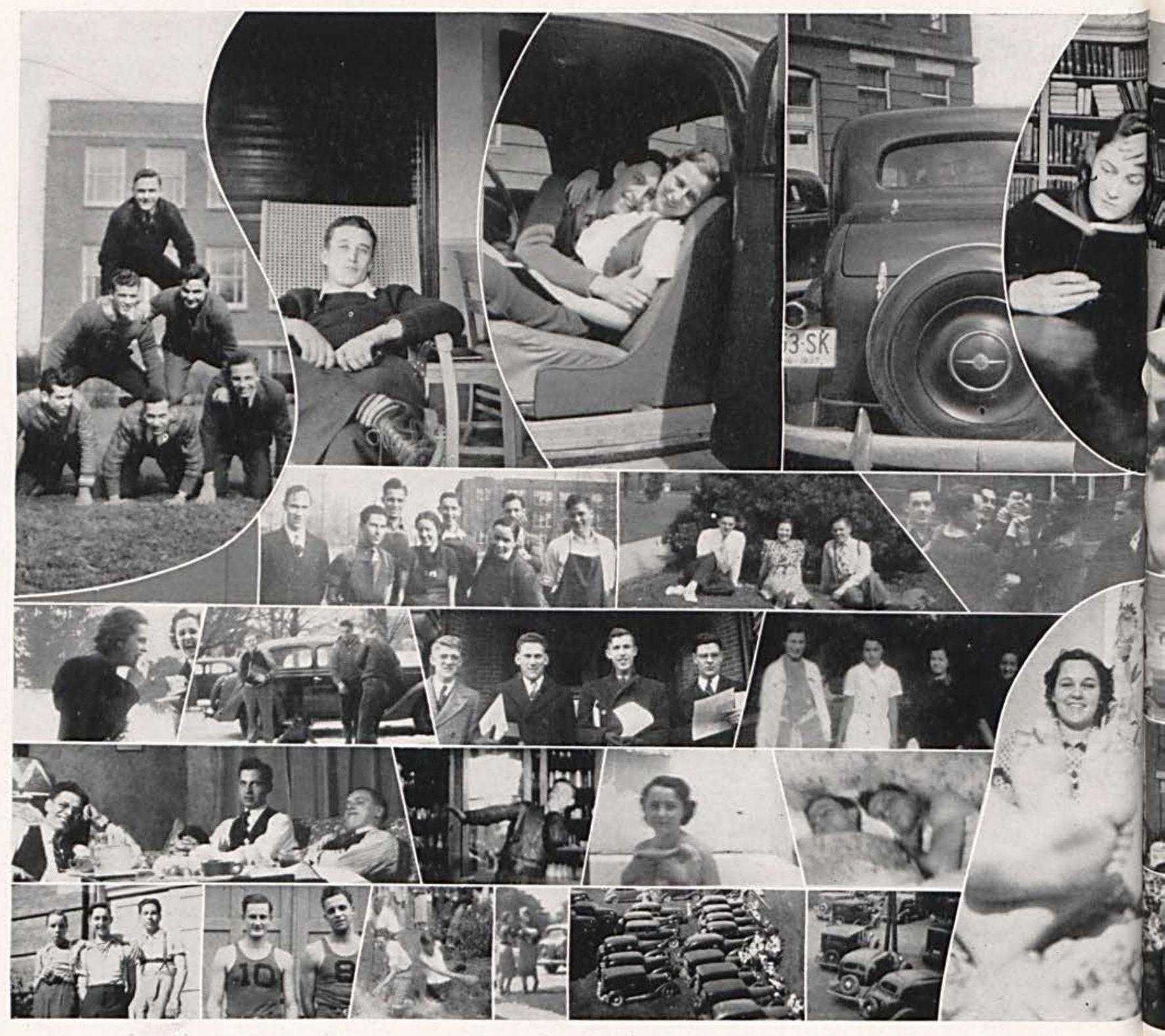

WHAT YOU,

THE 1938 CEDRUS 


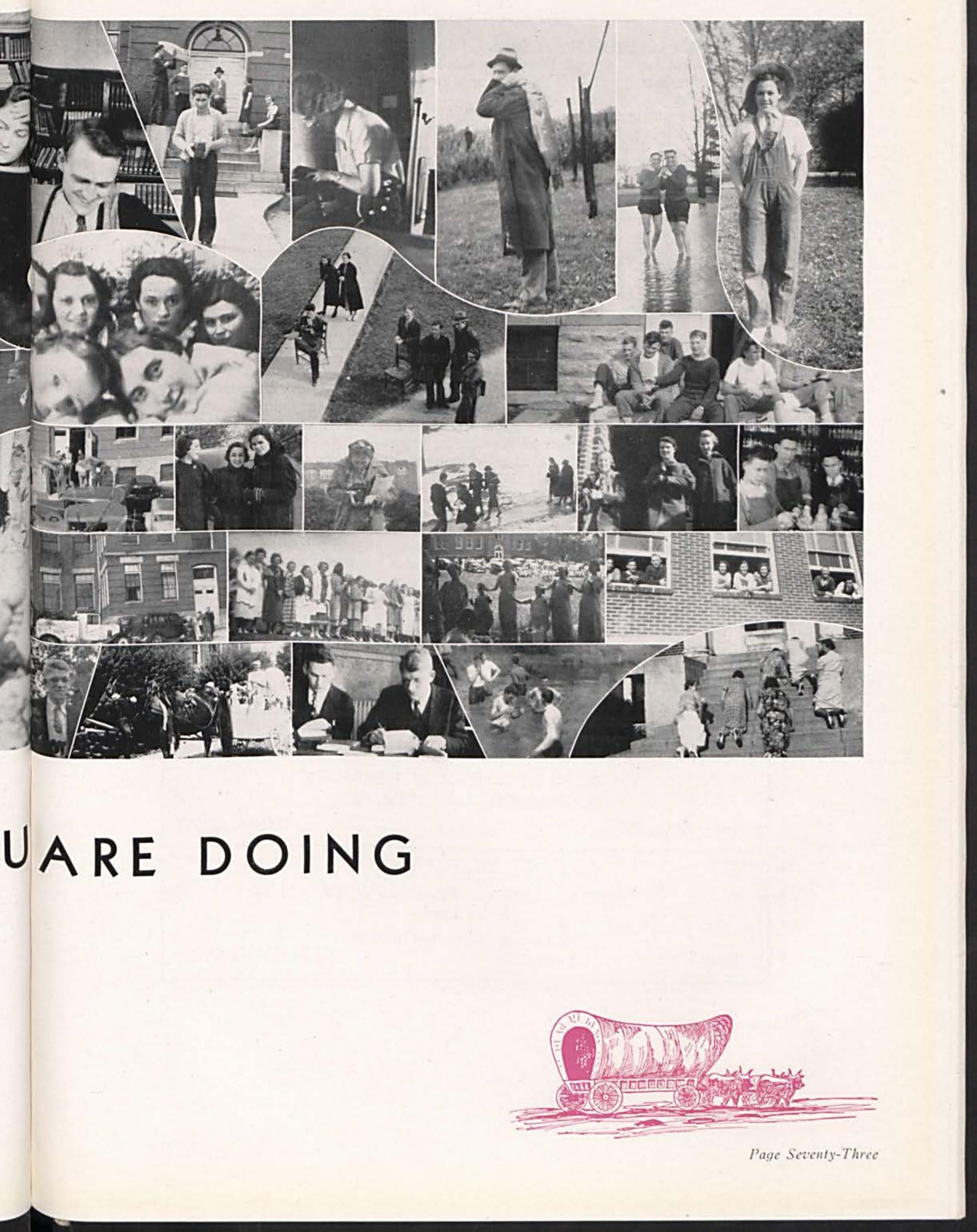




\section{COLLEGE CALENDAR}

Sept. 6-7 We saw Harold Shaw's dream girl signing up the students.

Sept. 8 First day of school. Everyone makes new acquaintances and renews old ones.

Sept. 9 Presbyterian party in the form of a track meet. Fox wears Walker's Pants.

Sept. 10 Election of class officers.

Sept. 14 Sophomores hold feed at Bryan Park.

Sept. 15 Freshies get ducked in Willow Bend. Brrrr... it's cold.

Sept. 16 Y.W. Tea at Jane Frame's. Pajama parade... one freshman girls gets wet.

Sept. 19 Founders' Day. Anniversary of founding of Cedarville College-convocation services.

Sept. 21 Y. M. and Y. W. Mixer-cider, doughnuts, and a good time.

Sept. 23 Seniors have a wiener roast at Rachel Creswell's. - Shaw looking frantically for glasses-damp ground-slick shoes-Miss Basore meets ground.

Sept. 29 Methodists throw a party - snake dance through town.

Oct. 4 Dramatic Club sponsors a hay ride-Miss Santmyer gets trampled onCecil Thomas loses his shoe-Benny tries to hit all the light posts.

Oct. 12 Pledge meeting for Alpha Theta Tau.

Oct. 20 Chi Sigma Phi entertaines the pledges with a tea at Pauline Ferguson's.

Oct. 28 It's the Hallowe'en party. Benny McNeal and Mary Johnston walk off with prizes as preacher and wife. How about it Benny?

Nov. I Dramatic Club presents "The Florist's Shop."

Nov. 4 Mid pomp and ceremony Miss Bickett becomes Mrs. Creswell. Junior Skating Party at Dayton-Linton and Anderson give a display of falls.

Nov. 8 College Students go to High School to hear Dr. T. Z. Koo of China. He tells of the condition of the Chinese government and his views of the war.

Nov. 10 Belling party for Mrs. Creswell-Noah wrecks Anderson's car.

Nov. 19 Y.W. Commital service dedicated to the memory of Frances McChesney.

Nov. 24 Special Thanksgiving service-We should be thankful for our many blessings. Thanksgiving vacation starts.

Dec. 4 Basketball season starts with a bang. We beat Springfield Y. M.

Dec. 7 Wilberforce wins an overtime by one point. Heartbreaking.

Dec. 9 The college actors present the well known stage and screen success, "The Late Christopher Bean."

Dec. 13 Secret Pal Party is held at McKibben's. How surprised everyone is to find who had been so nice to them.

Dec. 14 Roads icy, slip and slide, and maybe the ditch.

Dec. 15 Alpha Theta Tau supper, formal initiation, and rush party.

Dec. 16 Lost to old rival, Wilmington. Chi Sigma Party at Library.

Dec. 17 Christmas Vacation begins. Hurray!

\section{DETRICK MOTOR SALES \\ HUDSON 112 - HUDSON TERRAPLANE HUDSON "6" - HUDSON "8"}

Phone: MAin 966

XENIA, OHIO

$$
\begin{gathered}
\text { C. L. MCGUINN } \\
\text { COAL - SEED - GRAIN - WOOL } \\
\text { Purina Feeds } \\
\text { Custom Grinding and Mixing }
\end{gathered}
$$

Phone 3

CEDARVILLE, OHIO 
Dec. 29 Chi Sigma Phi has luncheon for alumnae and initiates its pledges.

Jan. 4 School starts again, back to the old grind. Jane Hampton creates a sensation by changing her name.

Jan. 14 Played Defiance there-lost by one point. Such luck!

Jan. 15 Played Giffin, a new foe and an easy one.

Jan. 17 Everyone cramming. Tomorrow, exams.

Jan. 18-20 Exams, cramming, headaches. Did we make it?

Jan. 20 Yellow Jackets played Bluffton. Victory is sweet.

Jan. 24 Registration for new semester. Grades are out. Everyone passed.

Jan. 25 A clean slate again - what a grand feeling! New faces, new courses, new activities, a new semester. Another game with Wilberforce-lost again in an overtime by one point.

Jan. 26 Snow, snow, and more snow.

Jan. 27 Bobsled riding for both high school and college students.

Jan. 28 The "squad" trounced Springfield Y again.

Jan. 29 Giffin was again an easy foe for the "gang."

Feb. 3 Junior party at McClellan's. Roy learns to eat chili and like it.

Feb. 4 Day of Prayer for colleges. President Tullos of Wittenberg gives the address.

Feb. 5 Old grads back for homecoming. Record breaking attendance. Alumnae and students thrilled to see the team beat Rio Grande by one point in nip and tuck battle.

Feb. 7 Debate team entertains Rio Grande.

Feb. 8 Glee Club has supper at Mrs. Creswell's and makes candy to sell.

Feb. 9 "Organization" pictures taken by Buckles.

Feb. 10 Pep meeting-burned Defiance.

Feb. II Defeated Defiance, repeating the performance of exactly a year ago.

Feb. 14 Yellow Jackets defeat Bluffton and win again. Cecil Thomas receives another letter from Lane Bryant! A $\mathrm{TT}$ "goat-ride" at Mrs. Kling's.

Feb. 15 Charlotte Turner entertains for the Freshmen.

Feb. $17 \mathrm{A \Theta T}$ pledges start something new in the way of jewelry ... soap necklaces.

Feb. 18 Theta pledges model some clever new "mad hats.

Feb. 22 What a day for important events! Besides being Washington's birthday it is also the grand classic of the year-the game between those arch-rivals, Cedarville and Wilmington. Cedarville again bowed but not without putting up a good fight and worrying their rivals a great deal. Chi Sigma Phi has a pot-luck supper at Geneva's-Jessica Taylor is initiated.

Feb. 28 First game of the class tournament-Sr. and Sophs-Sr. won-thanks to Ken Sanderson!

\section{EVANS RESTAURANT \\ LUNCHES AND SHORT ORDERS \\ Xenia Av. \\ CEDARVILLE, OHIO}

Phone 58

\section{WRIGHT’S}

White Villa Grocery

CEDARVILLE, OHIO

\section{Compliments of}

Shane's Barber Shop

CEDARVILLE,
$\mathrm{OHIO}$ 


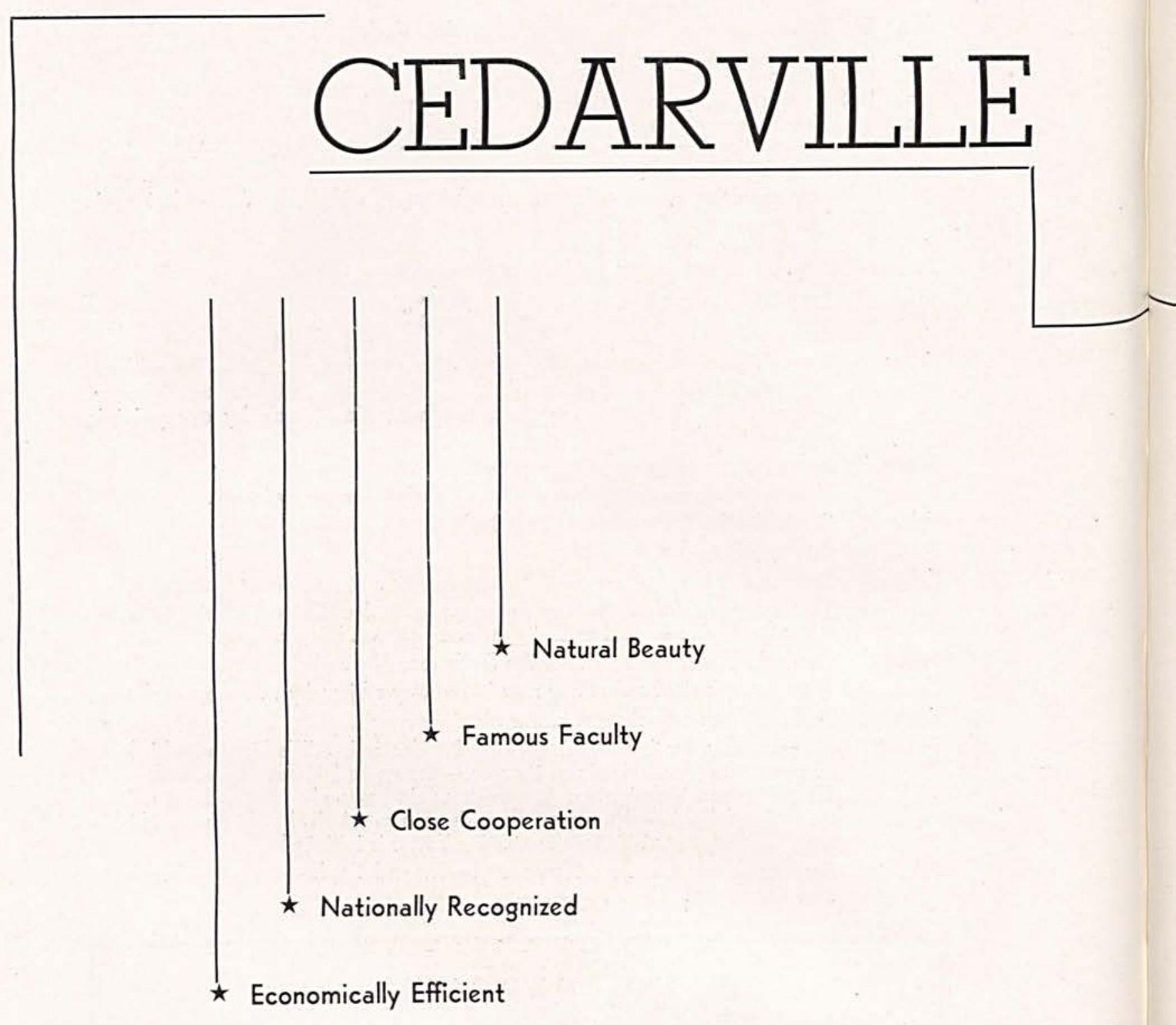

THE 1938 CEDRUS

Page Seventy-Si.r 


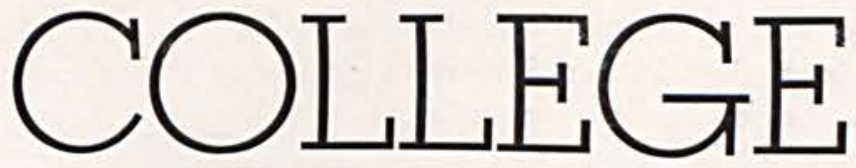

The College is recognized by the Department of Public Education of the State of Ohio, and by the leading universities. The faculty is experienced and thoroughly trained.

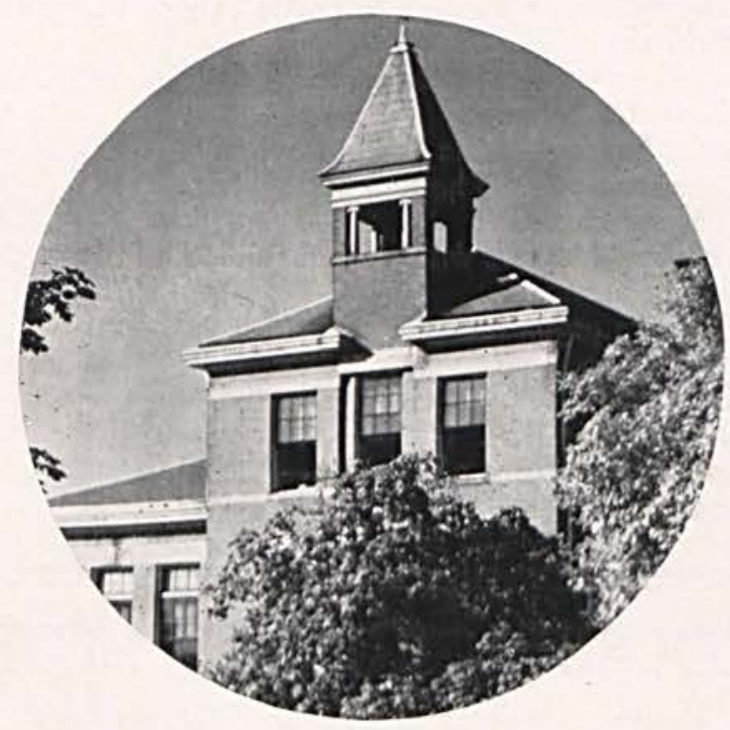

\section{COME TO CEDARVILLE COLLEGE}

Write for Catalogue and Information

W. R. McCHESNEY, PH.D., D.D., PRESIDENT

Cedarville, Ohio 
Mar. I Junior's and Freshies play-Freshies win.

Mar. 3 Sr's defeat Freshies to win the class tournament and are presented a beautiful gold and blue cup.

Mar. 6-20 Every night except Saturday the three churches of Cedarville hold revival services. Many College students attended and some helped conduct the services and furnish music.

Mar. 19 Girl's gym class goes to "Play Day" at Cincinnati U. and enters the basketball and volley ball games, winning both games. Clay acts as guide, chauffeur and "coach."

Mar. 21 Y. W. sponsors a "mad hatter's" party and attempts to pull the mock wedding before the boys' very eyes - but Mary was kidnapped.

Mar. 27 Women's Bible Reading Contest-Rachel Creswell wins.

Mar. 30 Spring Vacation begins. Jr's and Sr's have a class party at Roy's.

Apr. 5 Spring Vacation ends-buckle down again!

Apr. 6 Mary Johnston's birthday - gets paddled with a tray. Poor tray.

Apr. 8 The cliffs have proved to be the favorite haunt of those involved in courtship.

Apr. 10 College Mixed Chorus sings Stainer's "Crucifixion" over WHIO, Dayton. Congratulations on a splendid performance.

Apr. 12 Glee Club Skating Party at the rink at Glen Haven at Yellow Springs. We hear that Seamon, Ankeny, Labig, and Linton are perfect in their threepoint landings.

Apr. 14 Boarding Club Party-Roast pork and all the trimmings, Ummmm.

Apr. 17 College Mixed Chorus presents an Easter Service at the Presbyterian Church.

Apr. 21 Y. M. Minstrel.

Apr. 29 First Baseball game with Wilberforce.

May 6 Mother-Daughter Banquet.

May 12 Junior-Senior Banquet at the Y. M., Dayton.

May 13 Senior Vacation begins. I hope, I hope, I hope.

May 20 Annual College Picnic.

May 25-27 Final exams-How we wish we had studied a little harder.

May 29 Baccalaureate Service.

May 30 Martha Bryant's organ recital.

May 30 Faculty Reception.

May 31 Senior Class Play.

June I Cedar and Athletic Day.

June 2 Annual meeting of Board of Trustees-Alumni Banquet.

June 3 Commencement.

\title{
CROUSE'S GROCERY STORE
}

\author{
FRUITS - VEGETABLES - HOME KILLED MEATS
}

Phone 40

CEDARVILLE, OHIO

\section{COVAULT'S BEAUTY SHOP}

\author{
Every Beauty Service
}

Phone 434

XENIA, OHIO

Page Seventy-Eight 


\section{HAMMAN'S DAIRY MILK}

Single and Whipping Cream

Phone 197-R3

CEDARVILLE, OHIO

\section{HILL TOP GREENHOUSES}

H. C. FENKER, Florist

Phone 31

JAMESTOWN, OHIO

Vogue Shop

Springfield, Ohio

Specializing in

UNIVERSITY-STYLED

CLOTHES FOR MEN
C. E. Masters

GROCERY AND

MEAT MARKET

Phone 44

CEDARVILLE, - - - OHIO

Subscribe to

VETERINARIAN

Phone 81-R2

Cedarville, O.

"WHISPERING CEDARS"

Compliments of

THE COZY THEATER

Cedarville, Ohio

\section{Brown's Drugs}

THE REXALL STORE

The Best in Drug Store Service Visit Our Fountain

Main Street
Cedarville, Ohio
Galloway \& Cherry

FURNITURE - DRAPERIES FLOOR COVERINGS

34-36-38 West Main St.

Phone 4 XENIA, OHIO 


\section{THE LOW - DOWN ON THE HIGH - UPS WHISPERING CEDARS $1937-38$}

Overheard early in September, 1937; Russell Roberts: "Cecil, were you at the cliffs last night for the Sophomore party?" Cecil Thomas: (dreamily) "No, I was in heaven." - After the girls heard that Art Geake had never been kissed, it didn't take them long to break down what it took Art 19 years to build up. Art actually kissed a girl and he didn't even remember her the next day. The moon must have been shining in his eyes... Eugene Kavanaugh: "Why do they call Clara Belle Ankeney and Rachel Harriman the "Tonsil Girls"? Lank Roberts: "Because everybody's had them out." . . In October 1937, Mr. Swaim wanted to know what course in night school his son, Howard, is taking . . . Jim Anderson: "I guess you've been out with worse-looking fellows than I am, haven't you?" (no answer) "I say, I guess you've been out with worse-looking fellows than I am, haven't you?" Mary Johnston: "I heard you the first time. I was just trying to think." . . When John Fox steps out he really does it right. John had the heaviest date on Tuesday night December 7 th he ever had. We won't tell who it was because it might make the college girls jealous... Edna Anderson: "He couldn't write me a letter for two weeks because he broke his glasses and had to go to the Optimist." ... The three bachelors, Jim, Roy, and Benny met Dick Macknight Sunday night, April I0th, and what do you think was on his mind? "Fellows," he said, "Can you tell me where I can get some good muggin'?" ... Jean Elliott says she doesn't know why, but ever since she was little they have been trying to pin something on her. . . Can you imagine lrene Goodin looking for a jewelry counter in a ten-cent store? Well she found it but she decided to take the man instead of the jewelry... Some say that Foulks was vaccinated with a victrola needle dipped in I-Like-Me solution . . Thomas to Dr. Jurkat: "Could you tell Shaw why Mossbarger closed her eyes when he kissed her?" Jurkat: "I suppose it's because Shaw is so homely." . . Who in school goes around calling themselves "Bull" and "Boar." Shame on you girls.

\section{FOR QUALITY AND QUANTITY$$
\text { EAT AT NEAL'S }
$$ \\ Students Always Welcome}

THE 1938 CEDRUS 


\section{COLLEGE SONG}

Cedarville's a college in a grand old state, Builded by the hands of a Maker Great, Guiding eager students through the open gate. Of dear old Cedarville.

Fitting them for champions of the truth and right Arming them completely for the coming fight Leading them to victory over wrong to right At dear old Cedarville.

Senior, Freshman, Sophomore, Junior, too Join your hearts and efforts in everything you do "Onward, Upward!" be your motto still Follow closely the leading of our Dear old Cedarville

I want to go back to old C. C.

The best school in the land

And go to all the games again

And shout Rah! Rah!

To Alma Mater we will pledge

Our love and loyalty

I wan' to go back, I gotta go back

To old C. C.

At Cedarville College, we get our knowledge We slinga da ink an' pusha da pen along. At Cedarville College, we get our knowledge We slinga da ink an' pusha da pen along. We slinga da ink, da ink, da ink, And pusha da pen, da pen, da pen, We slinga da ink an' pusha da pen along. At Cedarville College we get our knowledge We slinga da ink, an' pusha da pen along.

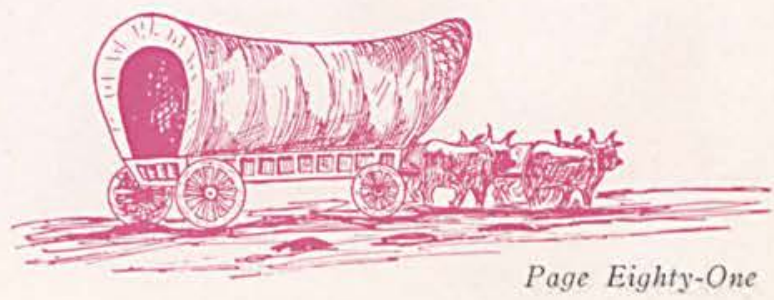




\title{
THE CEDARVILLE HERALD
}

\author{
COMMERCIAL -:- CATALOG \\ JOB PRINTING
}

Let us give you an estimate on your printing

Paul Edwards

DODGE — PLYMOUTH

DODGE TRUCKS

Used Cars

South Main St.

Phone 147

CEDARVILLE, $O$.
Compliments of

Cedarville Dolomite

Products

INCORPORATED

LIMESTONE PRODUCTS

Phone 76

CEDARVILLE, $O$.
HARDWARE

TIN SHOP

A. E. HUEY

Phone 2-128

CEDARVILLE

$\mathrm{OHIO}$
The

\section{Criterion}

Value First Clothiers

XENIA, OHIO

\section{THE XENIA NATIONAL BANK}

Over a Century of Community Service

CAPITAL ACCOUNT

$\$ 385,000.00$

Phone 114
RESOURCES OVER $\$ 2,000,000.00$

XENIA, OHIO 


\section{The Cummings and Creswell Co.}

$$
\begin{gathered}
\text { COAL - FEED - GRAIN } \\
\text { WOOL - LIVESTOCK }
\end{gathered}
$$

Phone 100

Xenia Candy Kitchen

Restaurant and Fountain Service

XENIA

$\mathrm{OHIO}$

\section{NAGLEY'S GROCERY}

"The Corner Store"

Phone 104

\begin{tabular}{|c|c|c|}
\hline \multirow{2}{*}{$\begin{array}{l}\text { Lang Chevrolet } \\
\text { XENIA, OHIO }\end{array}$} & \multicolumn{2}{|c|}{$\begin{array}{c}\text { PICKERING ELECTRIC } \\
\text { ELECTRIC CONTRACTOR } \\
\text { DEALER }\end{array}$} \\
\hline & Phone 22 & CEDARVILLE \\
\hline $\begin{array}{c}\text { THE DAIRY STORE } \\
\text { PASTEURIZED DAIRY PRODUCTS } \\
\text { Daily Delivery }\end{array}$ & \multicolumn{2}{|c|}{$\begin{array}{c}\text { BEA'S BEAUTY SHOP } \\
\text { BEAUTY MADE MORE } \\
\text { BEAUTIFUL }\end{array}$} \\
\hline JAMESTOWN, O. & Phone 14 & DARVILLE, O. \\
\hline
\end{tabular}

CEDARVILLE, OHIO

RECO SPORTING GOODS FOR BOYS AND GIRLS

BASEBALL - SOFTBALL - TENNIS - GOLF - RACKETS - RESTRUNG FISHING TACKLE

\section{THE RECO STORE}

16 W. High St.

SPRINGFIELD, OHIO 


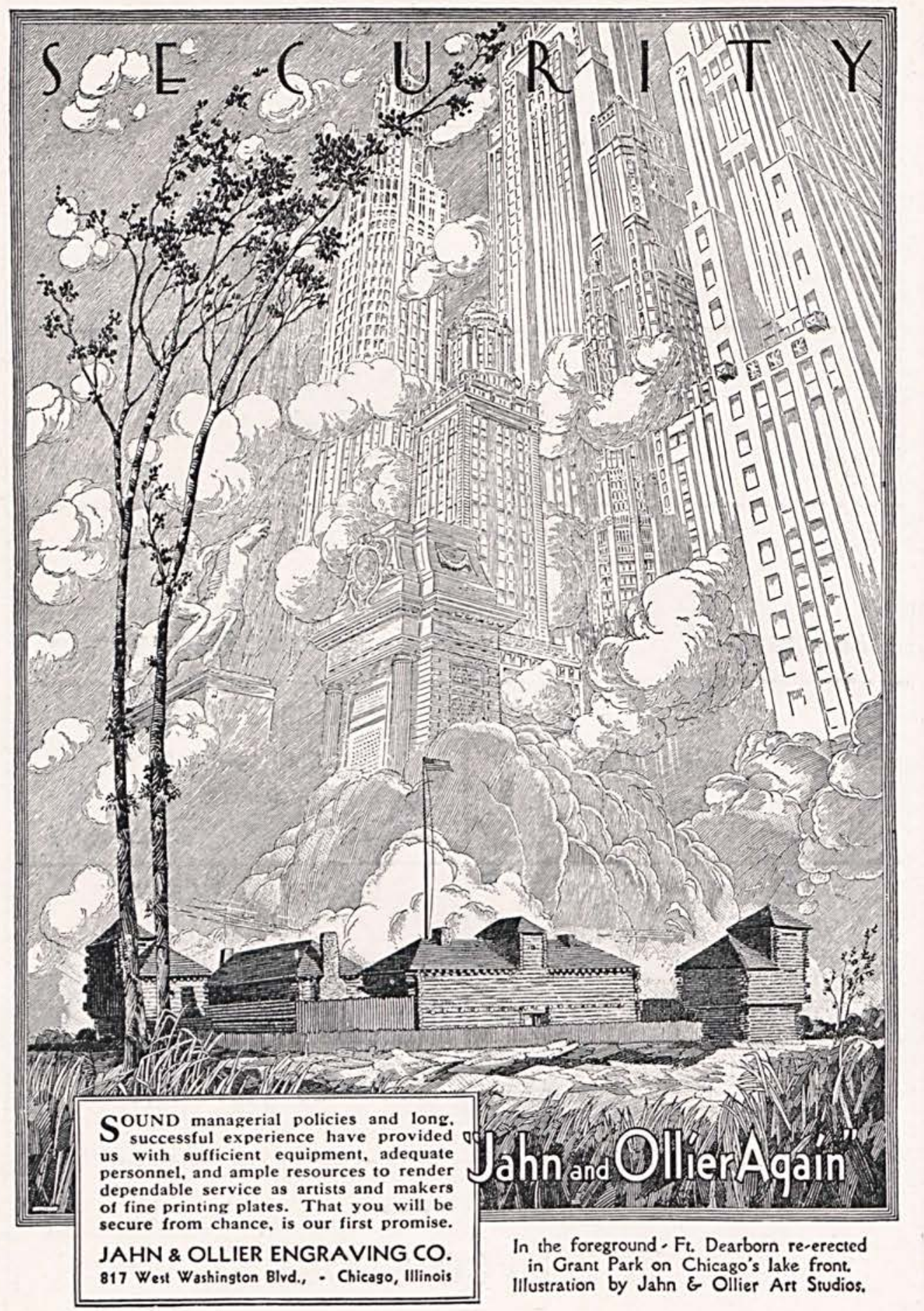

THE 1938 CEDRUS 
CEDARVILLE COLLEGE,

Cedarville, Ohio.

May 23, 1938.

To the readers of this book:

If we have been successful in enclosing our college life in these pages so that we may relive it in the days to come; if we have been able to show our admiration for our pioneer ancestors; if this book is deserving of any praise; then there are several to whom we should give our thanks.

We should be deeply grateful to Mr. William Freund, who, under no obligation to us, gave his time and ideas to the planning of this book. His help and encouragement were invaluable at a time when help was needed. We are also grateful to Clyde Walker who has made possible the carrying out of the theme of this book by furnishing some of the art work. Our thanks, too, should 30 to oll the members of the Cedrus Staff who have labored diligently and well in preparing write-ups, laying out the dummy, and seeking advertisements. We appreciate the cooperation of the Jahn \& Ollier Engraving Co., The F. J. Heer Printing Co., the Kingsport Cover Co., and the Marietta Centennial Commission. They have served us well.

At times our task has seemed difficult, but because of the willingness of all to help, we have been able to give you the 1938 Cedrus. Our hope is that it will mean as much to you in years to come as it has meant to us as we have seen it develop. Again we extend our thanks to those of you who have helped in the publication of this book.

Gratefully yours,

The Editor.

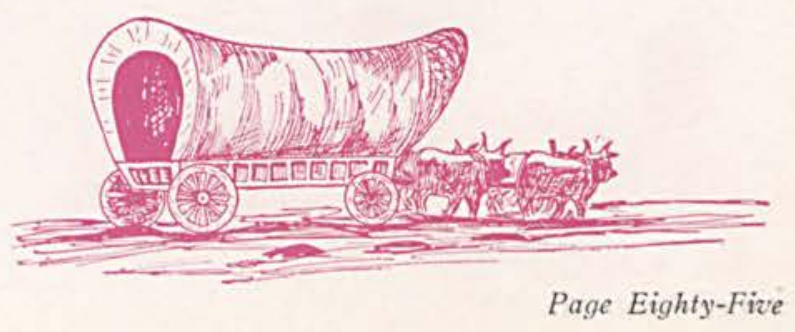


AUTOGRAPHS

THE 1938 CEDRUS

Page Eighty-Eight 


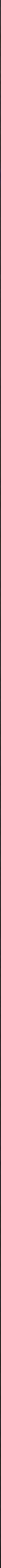





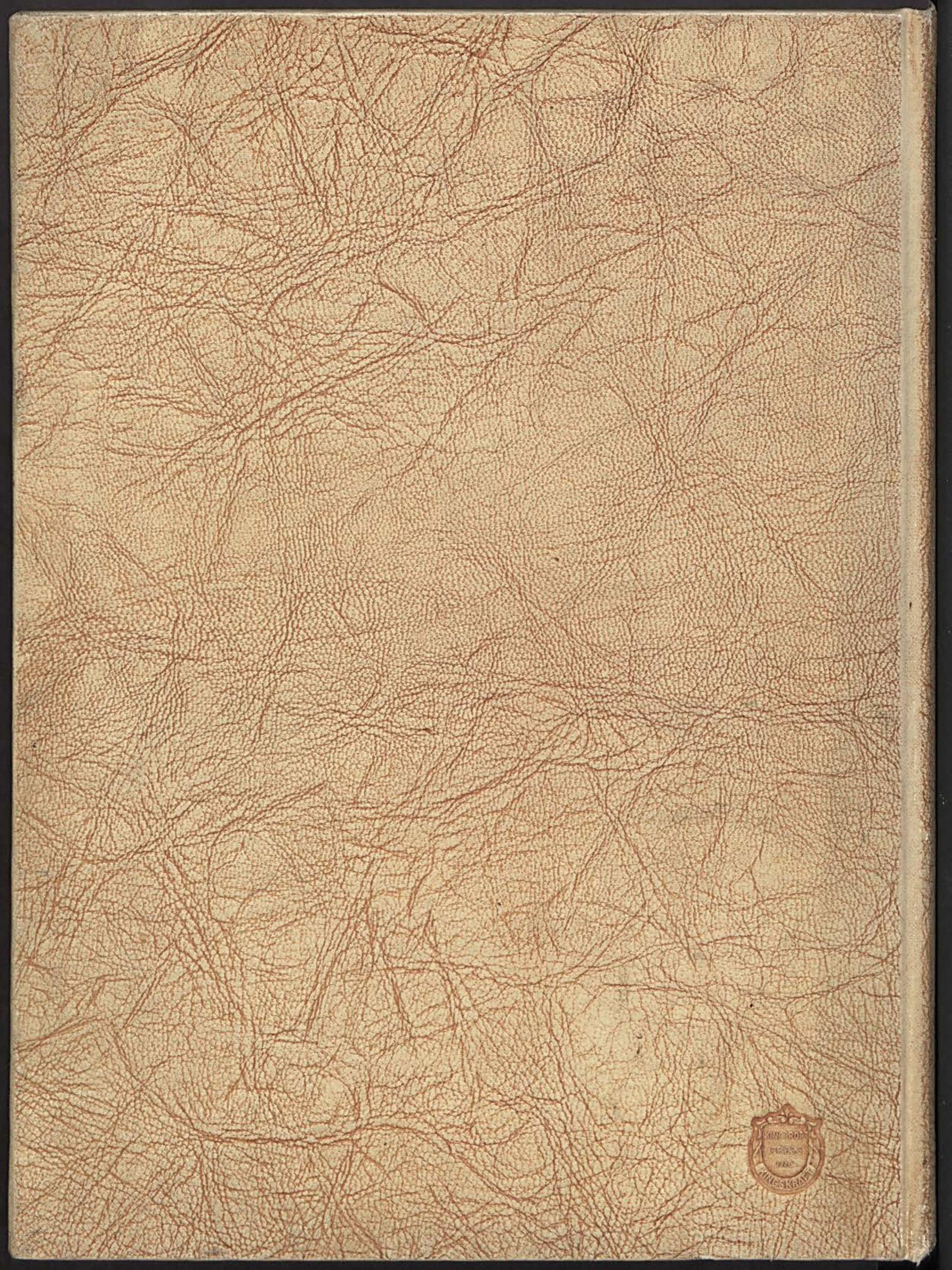

